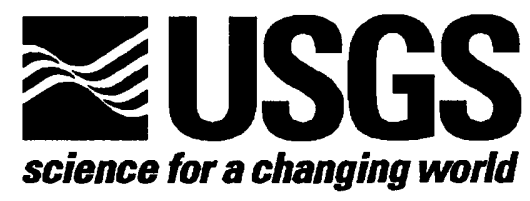

\title{
Preliminary mineral resource assessment of selected industrial and collector minerals of the Prescott National Forest, Arizona
}

By James D. Bliss ${ }^{1}$

Open-File Report 99-305

1999

This report is preliminary and has not been reviewed for conformity with U.S. Geological Survey editorial standards or with the North American Stratigraphic Code. Any use of trade, product or firm names is for descriptive purposes only and does not imply endorsement by the U.S. Government.

\section{U. S. DEPARTMENT OF THE INTERIOR}

U.S. GEOLOGICAL SURVEY

${ }^{1}$ U.S. Geological Survey, Tucson, Arizona 


\section{CONTENTS}

Non-technical Summary

Preface

Introduction _-_-_-_-_-_-_-_-_-_-_-_-_-_-_-_-_-_-_-_-_-_-_-_-_-_-_-_ 4

Graphics and statistics

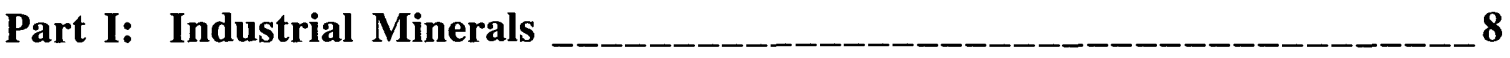

Aggregate _______ 8

Introduction

Geotechnical considerations __ 8

Surficial alluvial and crushed rock

Introduction 10

Verde Valley study 10

Geotechnical quality___ 11

Introduction 11

PI

Los Angeles Durability Test__ 12

Volume change___ 13

Grain-size analysis _ 14

Conclusion 18

Source Rock geology ___ 18

Introduction

Cenozoic volcanic rocks

Paleozoic Rocks__ 19

Proterozoic rocks 20

Iron oxides as an industrial mineral ___

Introduction _ 22

Sources of iron oxide in the PNF__ 22

Comparable sources of iron oxide in northern Arizona __ 24

Permissible geology__ 24

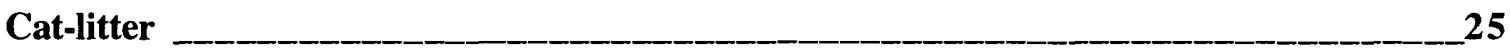

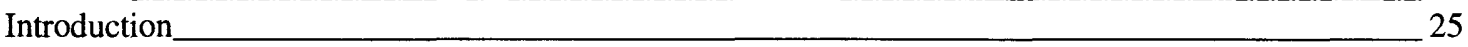

Background $\longrightarrow 25$

Material properties — 25

Mineral cat-litter materials

Possible sources of cat-litter in the PNF area __ 27

Volcanic tuff — 27

Clays _ 28

Gypsum — 29

Zeolites 29

Marketing issues__ 30

Landscaping Materials _____ 33

Part II: Selected Geologic Setting of Industrial Minerals

Industrial minerals from marine and lacustrine deposits_____ 34

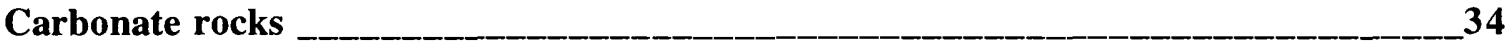

Gypsum ___ 35

Introduction 35

Background — 35

Geology

Models 36

Deposits and tracts ___ 36

Resource estimate status___ 37 
Lacustrine halite, sodium sulfate, and brines ___ 38

Background —_ 38

Geology — 38

Models

Deposits and tracts

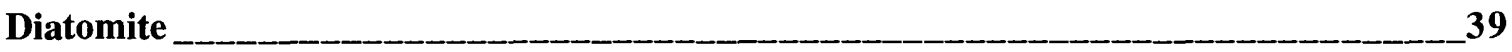

Part III: Collectable Minerals

Introduction_______ 40

Who collects minerals and why?

What are the factors effecting mineral value? _________________________________

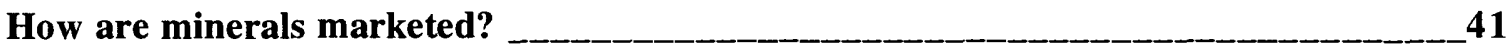

What are the types of minerals of interest to collectors? _-_

What are the prices collectors pay for minerals? ___ 43

Introduction__ 43

Gold-bearing specimens __ 44

Bulk Mineral types__ 45

Mineral specimen types

Mineral specimens classified by mineralogy _ـ 49

Bulk minerals and collectors specimens by mineralogy___ 51

What minerals are present in the PNF?

Introduction

Rare new minerals of the United Verde Mine fire ____ 53

Calcite

Jaspilite and tactonite__ 54

Other lapidary materials

Where are possible sources of mineral specimens? _ 56

References Cited _ 64

\section{FIGURES}

1. Approximate boundary of the Prescott National Forest (PNF) and of the three Ranger Districts (RD) 5

2. Data presentation using histrogram and boxplot 7

3. Boxplots of PI from observations in Quaternary and Tertiary mixed gravels, sands, silts and clay, and in Holocene alluvium $\mathbf{1 2}$

4. Boxplots of results of Los Angeles durability test, in percent loss, from observations in Quaternary and Tertiary mixed gravels, sands, silts and clay, and in Holocene alluvium 13

5. Boxplots of aggregate volume changes from observations in Quaternary and Tertiary mixed gravels, sands, silts and clay, and in Holocene alluvium 14

6. Boxplots of results of sieve analysis of grains less than 3 inch but greater than 3/4 inch observations in Quaternary and Tertiary mixed gravels, sands, silts and clay, and Holocene alluvium 15

7. Boxplots of sieve analysis of grains passing the 3/4 inch mesh sieve from observations in Quaternary and Tertiary mixed gravels, sands, silts and clay, and in Holocene alluvium $\mathbf{1 5}$ 
8. Boxplots of results of sieve analysis of grains passing the no. 4 mesh sieve from observations in Quaternary and Tertiary mixed gravels, sands, silts and clay, and in Holocene alluvium 16

9. Boxplots of sieve analysis of grains passing the no. 10 sieve mesh from observations in Quaternary and Tertiary mixed gravels, sands, silts and clay, and in Holocene alluvium $\mathbf{1 6}$

10. Boxplots of sieve analysis of grains passing the no. 40 sieve mesh from observations in Quaternary and Tertiary mixed gravels, sands, silts and clay, and in Holocene alluvium $\mathbf{1 7}$

11. Boxplots of grains passing the no. 200 mesh sieve from observations in Quaternary and Tertiary mixed gravels, sands, silts and clay, and Holocene alluvium. Note values are scale in logarithm base $\mathbf{1 7}$

12. Histogram and fitted normal curve of Fe grades for 11 samples of the Seligman (Cowden) hematite deposit 23

13. Comparison of retail values of cat litter prices $(\$ / t)$ in Socorro, New Mexico in 1994 to those in Tucson, Arizona in 199830

14. Histogram of 31 cat litter prices for sale in Tucson in $1998 \quad \mathbf{3 1}$

15. Bivariate scatterplot of cat litter package weights (lbs) and prices $(\$ / t)$ in Tucson, Arizona in $1998 \quad 32$

16. Histogram of package weights of 31 cat litters for sale in Tucson in $1998 \quad 32$

17. Boxplots of mineral prices ( $\$ / \mathrm{g}$ ) sold by bulk (unit weight) and sold as individual specimens $\quad \mathbf{4 4}$

18 Bivariate scatter plot of mineral value $(\$ / \mathrm{g})$ and mineral sample size (g) 49

19. Boxplots of prices (\$/g) grouped by types of mineral specimens $\quad \mathbf{5 0}$

20. Boxplots of mineral type prices $(\$ / \mathrm{g})$ sold by bulk and sold as individual mineral specimens 52

19 Boxplots of prices $(\$ / \mathrm{g})$ grouped by types of mineral specimens

49

\section{TABLES}

1. List of abbreviations used 2

2. Minerals of possible interest to casual mineral collectors and found in or adjacent to the PNF $\mathbf{4 2}$

3. Types and some common characteristics (in parentheses) of minerals sold in bulk 45

4. $\quad$ Examples of minerals and descriptions of mineral specimens $\quad \mathbf{4 7}$

5. Partial list of minerals found in, or adjacent to, areas of the PNF as identified in the compilation by Anthony and others (1995) unless noted otherwise $\quad 57$ 


\section{Non-technical Summary}

Industrial minerals are now the most important group of commodities produced in the Prescott National Forest area. Metals were historically important in the area including a major mine at Jerome (just west of Cottonwood and Clarkdale) and a scattering of mines in the Verde Ranger District (RD) and the southern half of the Bradshaw RD (fig. 1).

The three most important industrial minerals found in or adjacent to the Prescott National Forest include:

- Carbonate rocks used for fabrication of cement is a major product in the area. Production is underway to supply raw material to a cement plant near Clarkdale (fig. 1) which is one of the two cement plants in Arizona.

- Sandstone used for flagstone is a major product and found particularly in east Chino Valley Ranger District (fig. 1) and adjacent parts of the Kaibab National Forest to the north. Flagstone distribution is national and international.

- Aggregate produced from sand and gravel deposits usually found in valleys and valley margins is more likely to be outside of the Prescott National Forest. It is also produced from both unconsolidated basaltic cinders and consolidated basaltic flows that are more likely to be found on Forest Service land. Possible future increased aggregate production from crushed stone will likely impact Forest Service land.

Other industrial minerals suspected or known to be present in, or adjacent to, the Prescott National Forest include:

Clays used to fabricate vitreous clay permanent sewer pipe, pharmaceuticals and cosmetics.

Clays, zeolite and gypsum with possible suitablity for use in cat-litter fabrication

Diatomite with possible suitablity for filtering and fillers

Gypsum for use in cement fabrication and agriculture

Halite, sodium sulfate and brine constitutants with possible use in the chemical and food industries

Iron oxides used for pigments

Landscaping materials

Some of these industrial minerals have been extracted for use in the past or are now being worked. Others may be present but have yet to be identified as meeting end user specifications, or being extractable, or otherwise economically viable. 


\section{Preface}

The primary purpose of an assessment is to provide information useful to Forest Service land managers, other interested government agencies, and the public who are concerned about the quantity and quality of industrial minerals in deposits either likely present or yet to be discovered in the Prescott National Forest (PNF). A number of abbreviations are used and are listed in Table 1.

Table 1. List of abbreviations used.

\begin{tabular}{|l|l|}
\hline Abbreviation & \\
\hline$\$ / \mathrm{g}$ & dollars per gram \\
\hline$\$ / \mathrm{t}$ & dollar per metric ton \\
\hline AASHTO & American Association of State Highway and Transportation Officials \\
\hline ADOT & Arizona Department of Transportation \\
\hline AHD & Arizona Highway Department (same as ADOT) \\
\hline ASTM & American Society for Testing \& Materials \\
\hline $\mathrm{ft}$ & feet \\
\hline $\mathrm{km}^{2}$ & square kilometers \\
\hline $\mathrm{lbs}$ & pounds, English \\
\hline $\mathrm{m}$ & meter \\
\hline $\mathrm{mi}$ & mile \\
\hline $\mathrm{NF}$ & National Forest \\
\hline $\mathrm{PI}$ & plastic index \\
\hline PNF & Prescott National Forest \\
\hline $\mathrm{RD}$ & Ranger district \\
\hline $\mathrm{t}$ & metric tons \\
\hline$\phi / g$ & cents per gram \\
\hline
\end{tabular}

The report is divided into three sections. This includes section one on Industrial minerals, section two on selected geologic setting of industrial minerals, and section three on collectable minerals. See Table of Contents for details concerning what each section contains. This assessment is primarily a compilation of previously reported information about recognized industrial minerals found in the PNF. Most of the industrial minerals noted here are also described in assessments of the Coconino National Forest and Kaibab National Forest (Bliss, 1993, 1997).

What should and should not be included with industrial minerals is not clear on close inspection. The following definition is used:

Industrial minerals include all minerals, rocks, and other natural occurring substances (excluding water and minerals used for fuels) whose chemical and (or) physical characteristics are suitable for fabricating products of economic value. 
As with most industrial mineral definitions, some commodities are explicitly excluded. "The word "natural" has been included in the definition to exclude manufactured products, synthetic industrial minerals, and products that are a mix of natural and man-made components" (Greta Orris, written, commun., 1999). Note that industrial minerals need not mean just a single mineral. Industrial minerals also includes rocks that are aggregates of minerals. Most industrial mineral products retain some of the chemical and physical characteristics of the natural material in the fabricated product. Of course, as is typical of any attempt to develop definitions for industrial minerals, there are exceptions!

Material used in ornamentation (including gemstones) can also be included in the definition given above (albeit they are not "industrial" in the strictest sense) as they are expected to have some of chemical and physical characteristics (inertness, hardness, durability, desirable clarity, color, among others) producing desirable aesthetic qualities that give them economic value. Some degree of scarcity may be important as well. Many gem minerals usually have forms unsuitable for use in jewelry but may be suitable as an abrasive. This also lead to an examination of hobbies minerals as a general topic which is covered in some detail in section three of this assessment (see Table of Contents)

Assessment of industrial minerals requires a different set of tools and (or) models; most are not yet available. Also needed for industrial minerals assessment are ways to explicitly evaluate economics, proximity to markets, and deposit minability. These are very important in determining if deposits are likely to be considered for extraction. Industrial minerals' characteristics, both chemical and physical, are also important in determining if the material can be used. Only those deposits that meet some minimum level of chemical and physical characteristics will be considered as viable.

Successful assessment of many industrial minerals will require more detailed geologic mapping of surficial geology with greater emphasis on unconsolidated alluvium than that typically found on available geologic maps in the PNF area. Exceptions in the PNF region are the series of maps along the Verde River prepared by the Arizona Geological Survey (House and Pearthree, 1993; Pearthree, 1993; and House, 1994) and used by Cox (1995) in the evaluation of sand and gravel resources of parts of the Verde Basin. Because of the limitations noted, this assessment is described as "preliminary."

Two approaches can be used in assessing industrial minerals. Both are used here and it gives the report an uneven appearance. The first approach is to begin with types of industrial material or industrial material product and then survey the geology to identify what materials are needed to make the product. This is found in section one of this report and includes aggregates and cat litter. Additional information was added as most people are not familiar with some of the uses made of industrial minerals. The study on collector minerals in section three is somewhat similar in style to the 
approach used in evaluating aggregate and cat litter but it also took a much closer look at market and price structures.

The second approach is to review the geology and note which industrial minerals are likely to occur. This was the approach used in analyzing rocks formed in marine and lacustrine environments found in section three.

\section{Introduction}

Data about mineral deposits found in or adjacent to the PNF has come from various sources. Sources of some data on mineral deposits, prospects and occurrences come from two databases operated by the USGS-- MRDS and MILS. Additional sources for industrial minerals include Phillips (1987), Houser (1992) and Phillips and others (1998).

Most tracts are defined using stratigraphy or other geologic features that are seen on regional maps including the following: Weir and others (1989) for the geologic map of the Sedona 30' X 60' quadrangle; Ulrich and others (1984) for the Flagstaff $1^{\circ}$ by $2^{\circ}$ quadrangle; Moore and others (1960) for a small part of Coconino County in northeast PNF; and Arizona Bureau of Mines (1958) for other areas of Yavapai County. The PNF includes a small area of the extreme southwest edge of the San Francisco volcanic field that is described by Newhall and others (1987). Also used was an unpublished and incomplete 1:250,000 scale geologic map compiled by Louise Mohammond, Clay Conway, and Robert Miller. This map is identified as the Conway map in the report. Some of the sources used for their compilation map and not listed above include Anderson and others (1955), Billingsley and others (1988), Bryant and others (1992), Bryant, 1995, Conway and Gonzales (1995), DeWitt (1979, 1987), Hammond (1990), Heaman and Grotzinger (1992), Howard (1991), Krieger (1965), Nealey and Sheridan (1989), Potochnik (1989), Silver and others (1982a, b), Simmons and Ward (1992), and Wrucke and Conway (1987).

This report lacks figures showing geology. A new geologic map for the PNF is in preparation by other USGS geologists but is not available at this time. Simplified geologic maps as in Bliss (1993) were not done for this report following the recommendations of Liz Matthews (Forest Service, Flagstaff, verbal commun., 1997) who indicated that existing geologic maps would be used. However, a location map (fig. 1) shows a generalized outline of the CNF as well as Ranger Districts (RD) and selected towns, Little Chino Valley, and the Verde River which is adjacent to the Verde RD and east Chino Valley Ranger District. Nearly all tracts identified as permissive for various commodities (or deposit types) are identified by geologic unit(s). Readers who use the information herein need access to geologic maps (most sources of which are listed above.) 


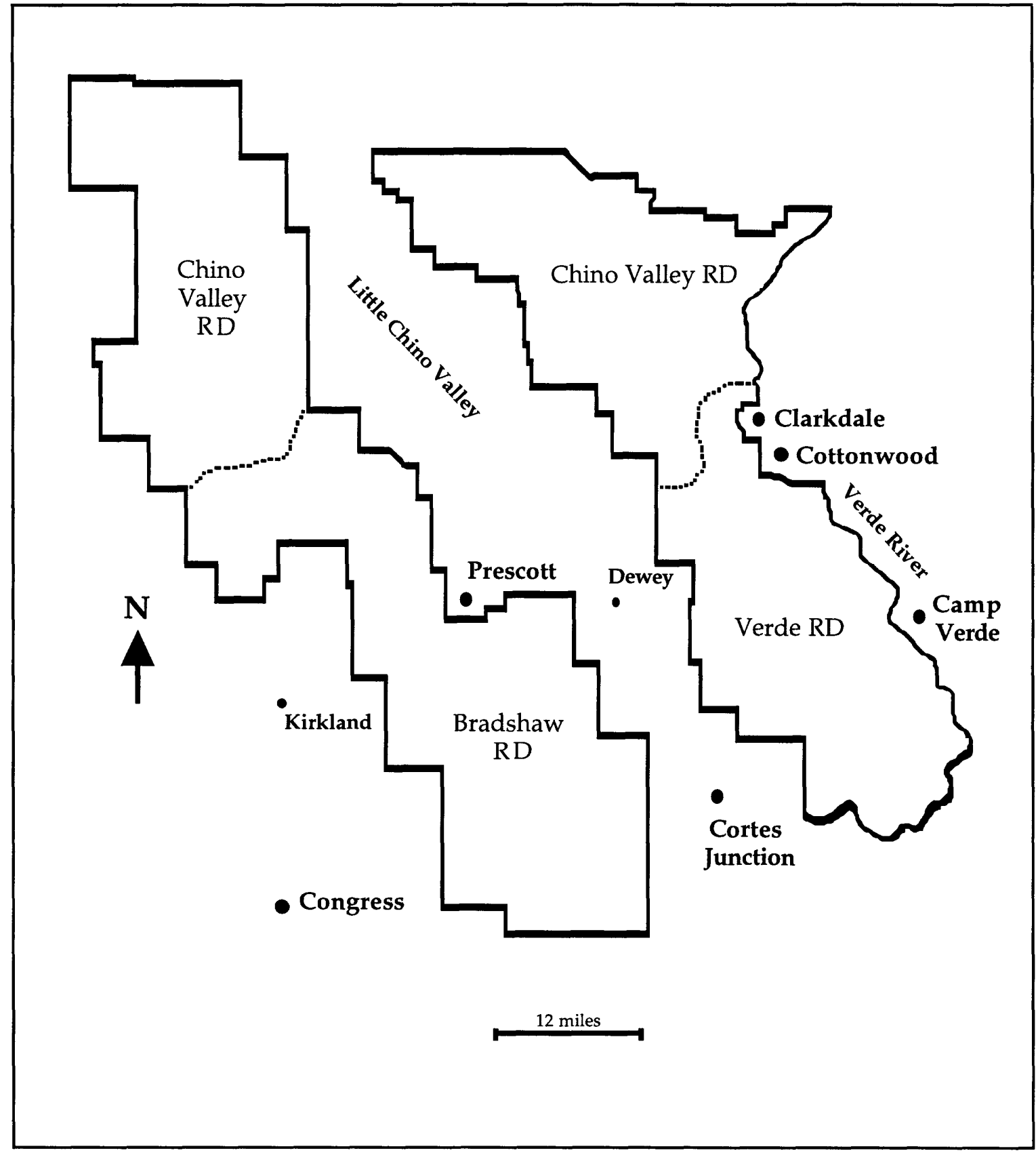

Figure 1. Approximate boundary of the Prescott National Forest (PNF) and of the three Ranger Districts (RD).

Assessments were completed in two adjacent national forests--the NF (Bliss, 1993) and the Coconino NF (Bliss, 1997). Both address industrial minerals. Much of the geology of the these two forests extends into the PNF. Therefore, some industrial minerals are not considered here in detail. For identification of pertinent geology and discussion about stone used in flagging, minor ashlar ${ }^{2}$, or dimension stone, see Bliss (1993, p. 19-28).

\footnotetext{
${ }^{2}$ Ashlar are rectangular or square stone blocks usually smooth on two parallel sides commonly used for
} 
Flagstone production from the Coconino Sandstone is an important industry in the PNF and the Kaibab NF to the north (Bliss, 1993). One correction is needed to the previous assessment of flagging. Extraction of flagging is easier where the sandstone bedding slopes in the same direction as the topographic slope, however, this situation does not seem to have been critical in locating most existing quarries. For identification of pertinent geology and discussion on uses of cinder, pumice, pumicite, and basalt and related lithologies, see Bliss (1997, p. 11-15) .

\section{Graphics and statistics}

Comparisons among variables addressed in this study were made using boxplots--an extremely useful diagram for determining the differences in distributions within and among categories. Figure 2A is a histogram of bulk specific gravity for carbonate rocks found in 51 quarries. Below the histrogram in figure $2 \mathrm{~B}$ is the corresponding boxplot using the same data as for the histrogram. The boxplot is construction by ranking the data values from smallest to largest. The value of the observation at the middle of the data set with an odd number of observations (that is, half the value fall above and half below) is defined as the median value. This would be the 26th observation in the ranked quarry data set. If the data are even numbered, a median observation is not present. It is calculated by taking the average of the two observations nearest to the mid point of the data set. The data is now divided into an upper half and a lower half. The box part of each boxplot is divided by an internal line that is the median value (fig. 2B). Each half of the data set is now treated as the whole data set was--both lower and upper half are themselves divided into two equal parts. These dividing lines correspond to the left and right edges of the box that contains 25 percent of the values above and below the median-- 50 percent of the data are contained within the box (fig. 2B). Lines called whiskers extend out from the box on both sides to vertical lines that are called fences. The fences bound 40 percent of the values above and below the median--that is, 80 percent of the observations are between the fences. Data beyond the fences are shown as points and account for the 10 percent of the lowest and 10 percent of the highest values in the data set. If a statistical difference was suggested in some comparison between the medians of boxplots, the nonparametric MannWhitney $U$ test was run and the results of the test are reported if the difference was found to be significant at the 5 percent confidence level.

The data for some boxplots were clustered in ways that made viewing the boxplots difficult. For that data, the $x$ axis where scaled as logarithmic based 10 and care needs to be used during the inspection of these figures.

building facing. 

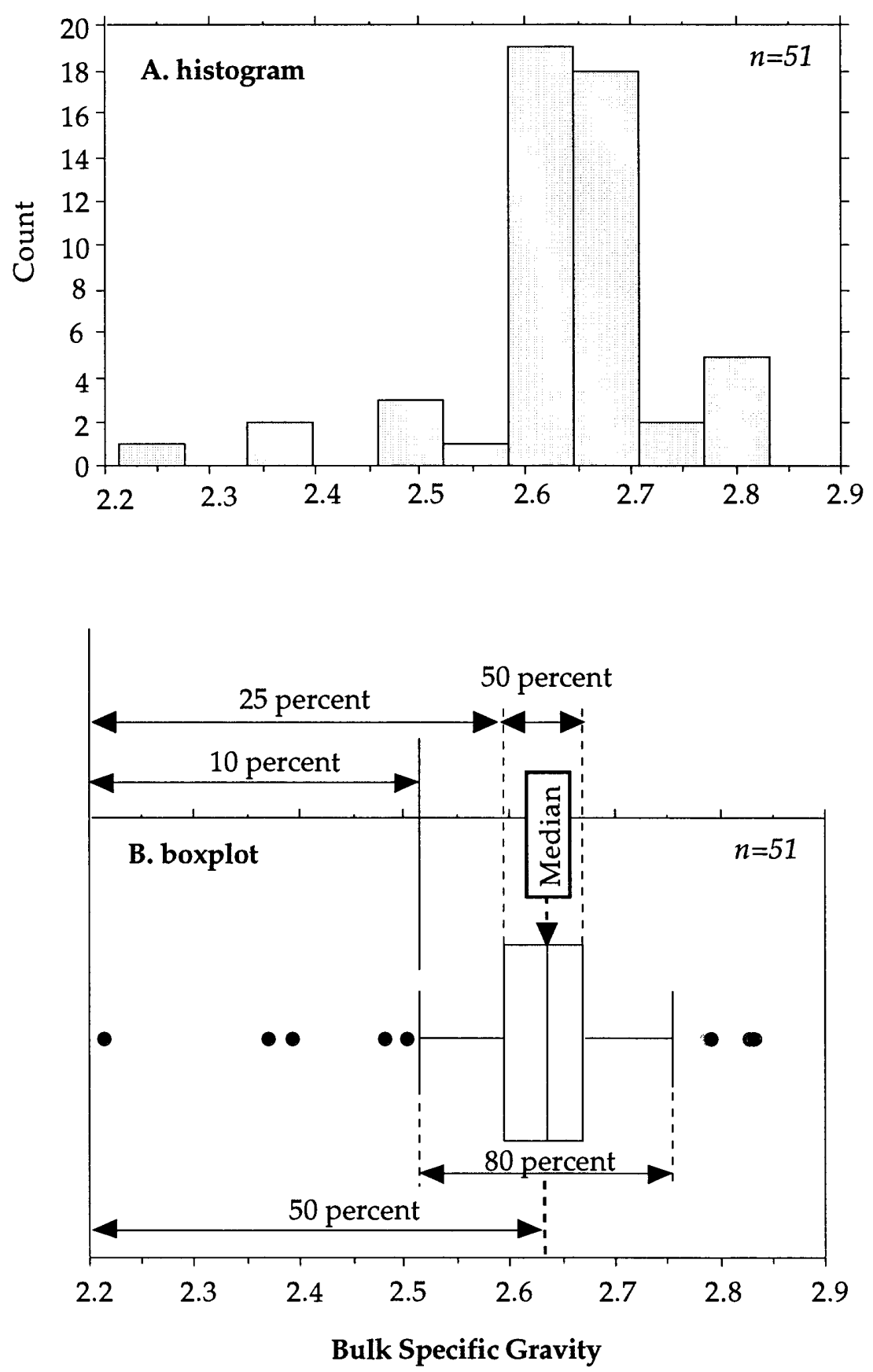

Figure 2. Data presentation using histogram and boxplot. 


\section{Part I: Industrial Minerals}

\section{Aggregate}

\section{Introduction}

Natural aggregate includes both crushed stone and sand and gravel. Processing is commonly limited to crushing, washing and sizing (Langer, 1988). Aggregate is obtained by crushing stone or mining unconsolidated surface material. Aggregates are classified as coarse or fine. Coarse aggregate have grains usually greater than sieve No. $4(4.76 \mathrm{~mm})$. Fine aggregates have particles passing a No. 4 sieve $(0.187$-in square opening, $4.76 \mathrm{~mm})$, but with little material passing the No. 200 sieve $(0.074 \mathrm{~mm})$. A few particles may be included between the $3 / 8$-in sieve $(9.52 \mathrm{~mm})$ and No. 4 sieve $(4.76 \mathrm{~mm})$ (Huhta, 1991).

\section{Geotechnical considerations}

For aggregate, the concept of "grade" as used for metal mineral deposit types may be replaced by "geotechnical characteristics." Minimum requirements for aggregates are found in specifications published by state and local government. Factors considered in these specification include local geology, climate, and intended end use. Specifications usually set by state and local governments also effectively restrict the definition of viable sand and gravel deposits. Two organizations which develop specifications are the American Society for Testing and Materials (ASTM) and the American Association of State Highway and Transportation Officials (AASHTO). Specifications for aggregate use in highway construction usually concern percent fines, grainsize distribution, durability, and reactivity. ASTM (1993), AASHTO, local and state governments offer test procedures and standards. For example, see the Arizona Department of Transportation (ADOT, 1990) standard specifications for road and bridge construction.

Zdunczyk (1991), Marek (1991) and Goldman (1994) suggest some general minimum specifications that are widely used. These include soundness or the resistance to disintegration by freezing and thawing. Coarse aggregate should exhibit a reduction of particle sizes of less than 10 percent using ASTM Test C88. ADOT requirements for aggregate in concrete placed above $1,400 \mathrm{~m}(4,500 \mathrm{ft})$ elevation are that they have a reduction of particle sizes of less than 10 percent using AASHTO test $T$ 104.

Absorption, reported as the increase in particle weight, should not exceed 3 percent using ASTM Test C127.

Fineness modulus, a single number index, expresses the coarseness or fineness of fine aggregates. White (1991, p. 13-8) gives the calculation as " adding the total percentages, by weight, of an aggregate 
sample retained on each of a specified series of sieves, and dividing the sum by 100." Finer materials have low values and coarser materials have higher values. Fineness modules should be between 2.3 and 3.1 in mix design of portland and asphalt concretes.

Fines, the material less than the No. 200 sieve $(0.074 \mathrm{~mm})$, should be no greater than 5 percent. ADOT requires fines not to exceed 1 percent.

Grading is a measure of the distribution of material among sieves. No more than 45 percent of grains should pass between two consecutive standard sieve sizes for fine aggregate. ADOT requires coarse aggregate gradation to conform to specifications in AASHTO T 43 when tested in accordance with the requirements of Arizona Test Method 201.

Hardness and strength, is the resistance of aggregate to disintegration by physical means including abrasion. Specifications give the Los Angeles abrasion (wear) test as one way to measure hardness and strength. For coarse aggregate, test results express as loss of material passing the No. 12 sieve $(1.68 \mathrm{~mm})$, are to be less than 30 percent using ASTM Test C131. ADOT (1990) requirements is the loss needs to be less than 40 percent using AASHTO T 96.

Sand equivalent is a test "to indicate the relative proportion of plastic fines and dust to sand size particles Marek (1991, p. 3-39)." The sand equivalent ratio should be no less than 77 percent using ASTM Test D2419. Specific gravity should be greater than 2.55 using ASTM Tests C127 and C128.

Other specifications which may be important include: fragment geometry, external coatings, impurities, fragment mineralogy and textures, flakiness, amounts of soft/friable fragments, level of hydration, alkali-silica reactivity, other types of chemical reactions, susceptibility to leaching, thermal incompatibility, excess polish and excess shrinkage.

For geologists and others examining or assessing sand and gravel deposits for possible consideration as a source of aggregate without use of testing facilities, two general characteristics should be noted:

1) Sand and gravel should make up at least 85 to 90 percent of the deposit. Boulders and cobbles may also be included in this calculation as they can usually be crushed. Most aggregate producers can tolerate raw material with up to no more than 10 to 15 percent fines (Drake, 1995). Fines add expense during extraction, dredging, hauling and disposal or stockpiling.

2) Sand and gravel deposits should be well graded, not well sorted. Wellsorted deposits may have only one or two mesh sizes and are commonly not economical because aggregate users need material with range of grain sizes as defined by the ASTM and other agencies. The portion of each particle size is also given within certain tolerances. Poorly sorted deposits are more likely to have a wide range of needed grain sizes in a continuous sequence. 


\section{Surficial alluvial and crushed rock}

\section{Introduction}

Sand and gravel is an important source of aggregate in the PNF area. Crushed rock has played a lesser role. A discussion on rock types which may be an important future source of crushed stone is found in the section on "bedrock geology" below. Sand and gravel production has come primarily from Holocene alluvial deposits consisting of unconsolidated clay, silt, sand, and gravel in modern drainages and flood plains and on terraces as much as $25 \mathrm{~m}$ $(80 \mathrm{ft})$ above flood plains from information compiled in a unpublished preliminary geologic map of the Prescott National Forest, including unit descriptions, prepared by Louise Mohammed, Clay Conway and Robert Miller, at a scale 1:250,000 (hereafter referred to as the Conway map). Other materials sometimes included with the Holocene alluvium are small deposits of colluvial, eolian, and fan deposits.

Holocene deposits are not abundant in the PNF but are found in some of the adjacent valleys. These include deposits found along Chino Wash and its tributaries including Walnut Creek, Williamson Valley Wash, and Little Chino Valley. Other notable Holocene alluvium is along Granite Creek north of Prescott, Big Bug Creek and its tributaries, and the Verde River that is discussed separately below. Part of this discussion concerns a series of terrace deposits flanking the Verde Valley and the northeast flank of the Black Hills.

Much of the valley in the PNF has material identified as Quaternary and Tertiary gravels, sands, silts and clay of mixed age and character. These materials are poorly studied as noted on the Conway map. Extensive outcrops are present along the margins of Chino and Little Chino Valley, as well as west of PNF in Skull Valley and in the Walnut Grove area.

\section{Verde Valley study}

Cox (1995) reported on the sand and gravel resources in the Verde Valley along the southwest edge of the CNF. Six tracts with geologic units known to contain sand and gravel deposits were developed using a number of recently published large scale maps of Quaternary geology including House and Pearthree (1993), Pearthree (1993), and House (1994). The quality of sand and gravel is qualitatively described for each tract as well as for the active channels of the Verde River. Cox (1995, map 1) identified sand- and gravel-bearing units as thin $(<12 \mathrm{~m}(40 \mathrm{ft}))$ or thick $(>12 \mathrm{~m}(40 \mathrm{ft}))$; well or poorly sorted; with or without atypical clast-lithologies (for the area); and those with or without riparian vegetation. Cox (1995) found that the details were sufficient in the large scale maps used in the study to successfully distinguish among the various types of sand and gravel resources using depositional setting or geologic age. This level of mapping of Quaternary geology is not common in Arizona for areas away from major cities. 
A second report on the sand and gravel resources in and near the PNF was also completed by Cox in 1995. A second section was added by J.D. Bliss and R.J. Miller focusing on the geotechnical characteristics of the Quaternary and Tertiary alluvium (Cox, 1999). One conclusion reached by Bliss and Miller is that in the longer term, the Verde River basin can be expected to go the way most areas in the US have gone when it comes to aggregate extraction. The role of National Forest lands could become greater under that scenario. As production declines from existing and perhaps from a few new sand and gravel pits in surficial sand and gravel deposits, producers will need to turn to crushing stone from quarries in suitable bedrock units. Many of these bedrock units may have their best exposures inside the Prescott or Coconino National Forests

\section{Geotechnical quality}

\section{Introduction}

A study was made of the aggregate quality of 198 pits in the PNF area using the geology found in Conway map. Pit locations and geotechnical data are found in the Arizona Highway Department (AHD) (1972) report on Yavapai county and ADOT (1975) report on Coconino County.

Two alluvial formations have adequate data for study and include the Holocene alluvial deposits, and Quaternary and Tertiary gravels, sands, silts and clay of mixed age and characters. Much of these formations are found in valleys and most sites are outside of the PNF. Data includes; plastic index (PI); Los Angeles durability test (LADT); swell (24 hour); and sieve analysis giving percent passing $3 / 4$ in. and sieve nos. 4, 10, 40, and 200 .

\section{PI}

The plastic index (PI) is a measure of sensitivity that aggregate has to moisture change and is important when aggregate is used in portland cement or asphalt concrete. White (1991, p. 13-42) defines PI as "the difference in the Atterberg liquid limit and plastic limit moisture contents." It is a value without a unit. A PI of 4 is the maximum allowed as stipulated in ASTM D 3515 for materials used in asphalt concrete mixtures (White, 1991). The AHD (1972) used several PI standards. These include ones where PI was not detected or was to be less than 5 or 10 depending on aggregate classification. Testing was to be executed in accordance with the requirements of AASHTO T 90 (AHD, 1972). Maximum allowable PI values are dependent on which of the 50 categories of aggregate types are in effect.

In this study, PI observations for 75 sites in Holocene alluvial deposits have a median PI value of 12, which is much less than the PI value of 20 for Quaternary and Tertiary mixed gravels, sands, silts and clay sites (fig. 3). For explanation of figure layout, see figure 2. However, the distribution of PI 


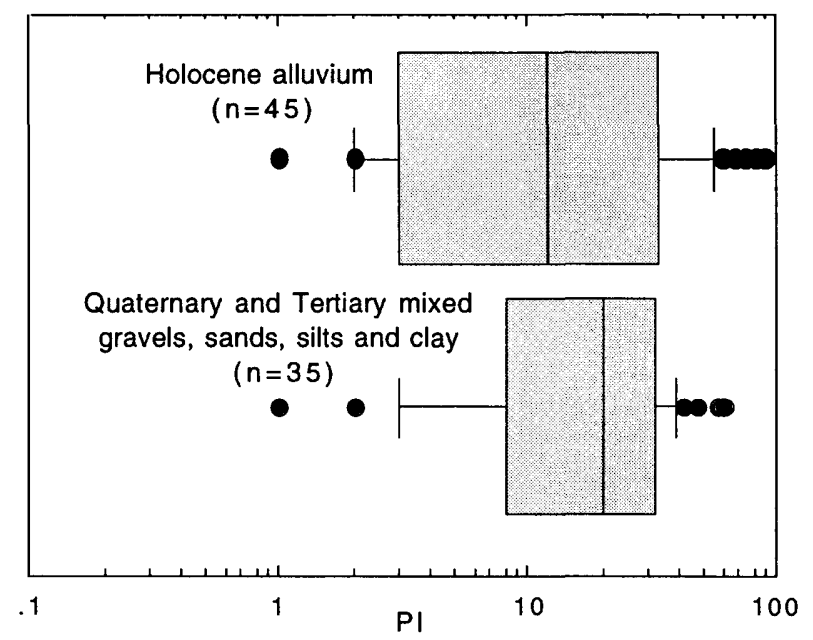

Figure 3. Boxplots of PI from observations in Quaternary and Tertiary mixed gravels, sands, silts and clay, and in Holocene alluvium.

values for Holocene alluvium completely brackets values for those from the Tertiary and Quaternary observations. When compared to specifications with maximum PI values of 4,5, or 10, the Holocene alluvial deposits are far more likely to be in compliance than those classified as Tertiary and Quaternary where nearly 75 percent of the sites are likely to have a PI of 8 or greater (fig. 1). The trend suggests that Holocene alluvial will likely provide a better aggregate as compared to that from Tertiary and Quaternary mixed gravels, sands, silts and clay sites.

\section{Los Angeles Durability Test}

In this study only 31 of the 198 sites have LADT results (including 25 observation in Holocene alluvial deposits and just 6 Tertiary and Quaternary mixed gravels, sands, silts and clay sites.) For Holocene alluvial deposits, 75 percent of the values (fig. 4) are less than, or equal to, the 40 percent loss maximum set by the ADOT (1990). The median loss is 27 percent. All 6 sites in the Tertiary and Quaternary materials are 40 percent or less. The median loss is 35 percent. 


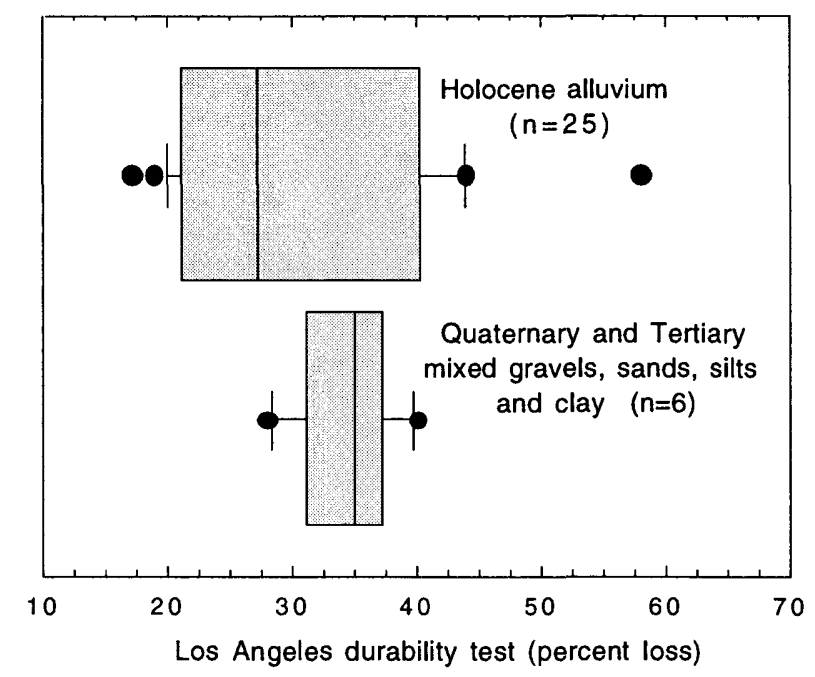

Figure 4. Boxplots of results of Los Angeles durability test, in percent loss, from observations in Quaternary and Tertiary mixed gravels, sands, silts and clay, and in Holocene alluvium

\section{Volume change}

Aggregates are best if they do not undergo changes in volumes. Most volume changes are related to changes in moisture content-- either as expansion or shrinkage. Volume changes are dependent on the number and nature of permeable pores or as result of the breakdown of grains during wetting and drying, particularly when aggregates are in unbound use (Marek, 1991).

Data is available giving maximum 24-hour volume change (here is an increase) of 81 samples measured using AASHTO 101, Method B (AHD, 1972). Standards in use at the time of testing set the maximum allowed volume increase of 0.06 for use in all classes of mineral aggregate and one class of aggregate for cover materials and slurry seal (AHD, 1972, Table 703-1 and 7041).

In this study, volume changes of the 61 observations in Holocene alluvial deposits are equally divided among those greater than and less than 0.06 (fig. 5). Note that the volume change axis in figure 5 is given in logarithm base 10. The median for the Holocene data is also the value of the maximum allowed volume change in 1972 specifications (fig. 3, line C). Half the values met the specifications (less than 0.06); half the values do not (greater than 0.06).

In contrast, about 70 percent of the 20 sites found in the Tertiary and Quaternary mixed gravels, sands, silts and clay (fig. 3, lower boxplot) have volume increases less than 0.06 . This suggests that one can expect fewer problems related to volume changes with this material when compared to aggregate from Holocene alluvium. 


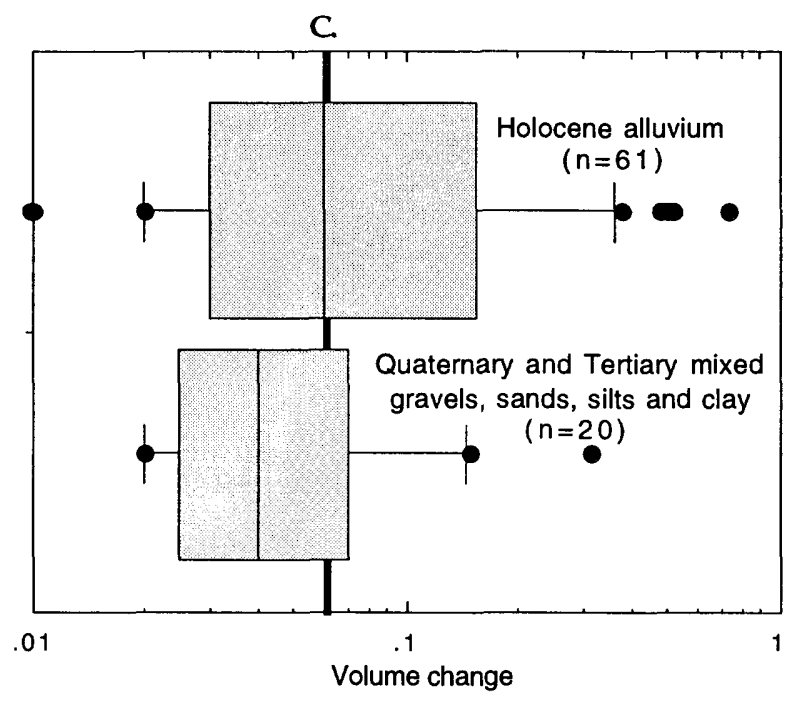

Figure 5. Boxplots of aggregate volume changes from observations in Quaternary and Tertiary mixed gravels, sands, silts and clay, and in Holocene alluvium. Note that volume change mesh are scaled as logarithmic based 10. $\mathbf{C}$ is the maximum allowed swell in the ADOT 1972 specifications.

\section{Grain-size analysis}

The largest grain sizes that are reported are for those passing the 3 in $(76.2$ $\mathrm{mm})$ mesh sieve that are retained on the $3 / 4$ inch $(19 \mathrm{~mm})$ mesh sieve. The amount passing the 3 inch mesh sieve was set as 100 percent (AHD, 1972). In this study, 96 observations in Holocene alluvial deposits have a median of 20 percent as compared to the 54 observations in Tertiary and Quaternary mixed gravels, sands, silts and clay sites with a median of 9.5 percent (fig. 6). Can we reject the hypothesis that the medians are equal? The results of the MannWhitney $U$ test suggests that there are 3 chances in 10,000 of the differences in medians being due to chance. Therefore, the medians are different and this is clearly true at the 5-percent confidence level as set previously. These results suggest that the Holocene alluvial deposits may be a better source of aggregate in terms of grain size as compared to the Tertiary and Quaternary mixed gravels, sands, silts and clay. The general rule is that coarse grained materials usually have a higher likelihood of providing the required grain size distribution to end users since results can be achieved by crushing if needed.

Materials passing the $3 / 4$ inch mesh sieve have clast sizes of $19 \mathrm{~mm}$ or less (fig. 7). Note this figure is a mirror image of figure 3 . The same pattern is seen in all comparisons of sieve analysis results (figs. 8-11)--that is, Holocene alluvium tends to have less fine-grain material than observations from the Tertiary and Quaternary mixed gravels, sands, silts and clay. For material passing the no. 4 mesh sieve the difference is large. The median percentage of material passing the no. 4 mesh sieve is 58 percent for the Holocene alluvium; the median percentage of material passing the no. 4 mesh sieve is 
75 percent for the Tertiary and Quaternary mixed gravels, sands, silts and clay (fig. 8).

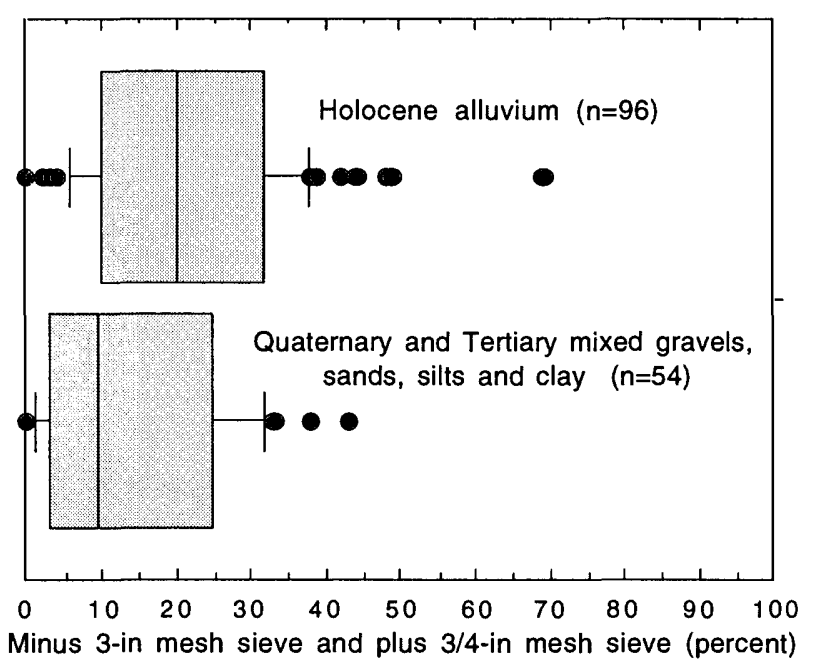

Figure 6. Boxplots of results of sieve analysis of grains less than 3 inch but greater than 3/4 inch observations in Quaternary and Tertiary mixed gravels, sands, silts and clay, and Holocene alluvium

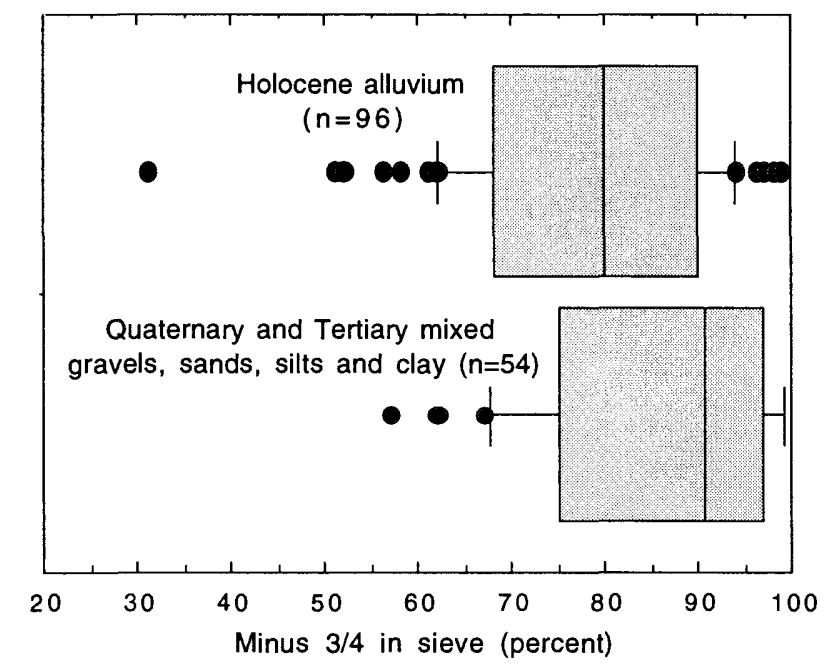

Figure 7. Boxplots of sieve analysis of grains passing the $3 / 4$ inch mesh sieve from observations in Quaternary and Tertiary mixed gravels, sands, silts and clay, and in Holocene alluvium. 


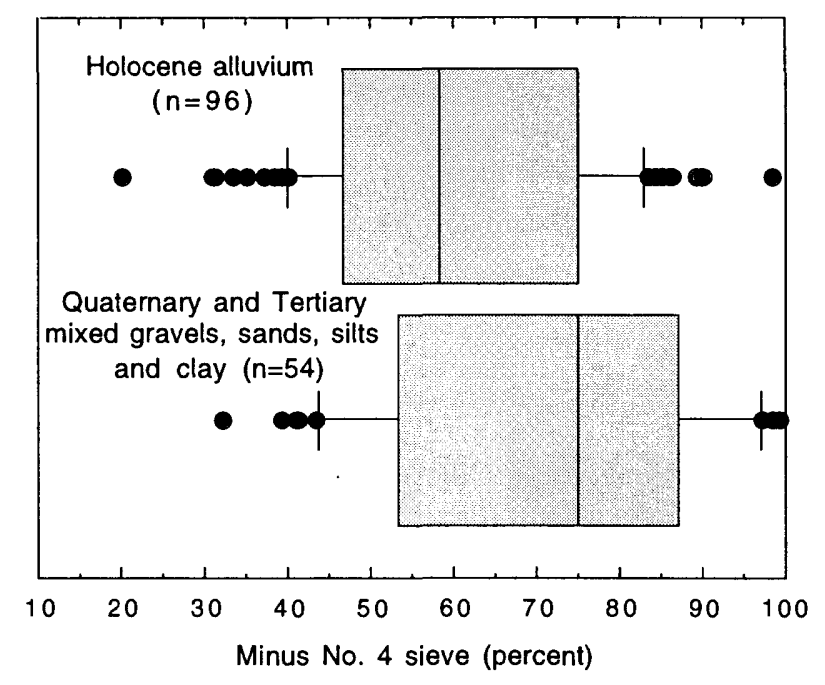

Figure 8. Boxplots of results of sieve analysis of grains passing the no. 4 mesh sieve from observations in Quaternary and Tertiary mixed gravels, sands, silts and clay, and in Holocene alluvium.

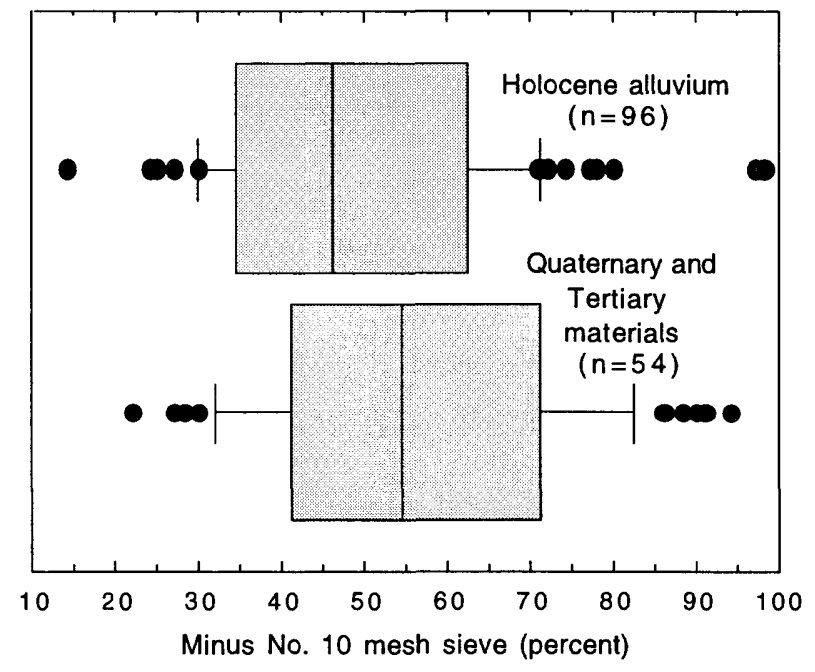

Figure 9. Boxplots of sieve analysis of grains passing the no. 10 sieve mesh from observations in Quaternary and Tertiary mixed gravels, sands, silts and clay, and in Holocene alluvium.

As noted in the introduction, 15 percent is the common maximum amount of fines (minus 200 mesh) seen in most sand and gravel operations in the US. Too much fines can prevent sand and gravel sites from being 


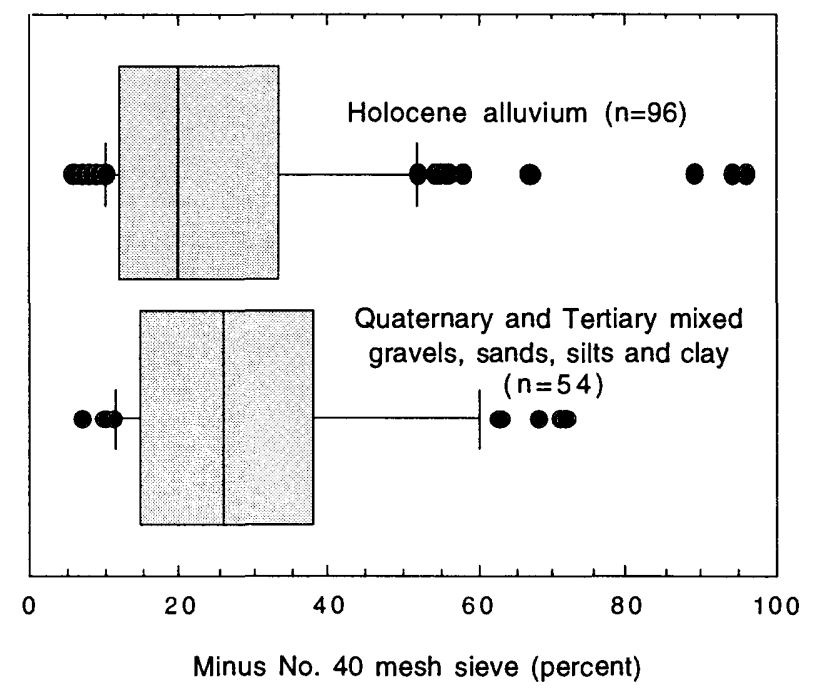

Figure 10. Boxplots of sieve analysis of grains passing the no. 40 sieve mesh from observations in Quaternary and Tertiary mixed gravels, sands, silts and clay, and in Holocene alluvium.

economic. Materials passing the no. 200 mesh sieve have clast sizes of 0.074 $\mathrm{mm}$ or less. In this study, the median of 96 observations of Holocene alluvium is 5 percent fines; for 54 observations of Tertiary and Quaternary mixed gravels, sands, silts and clay sites, it is 11.5 percent (fig. 11). Can we

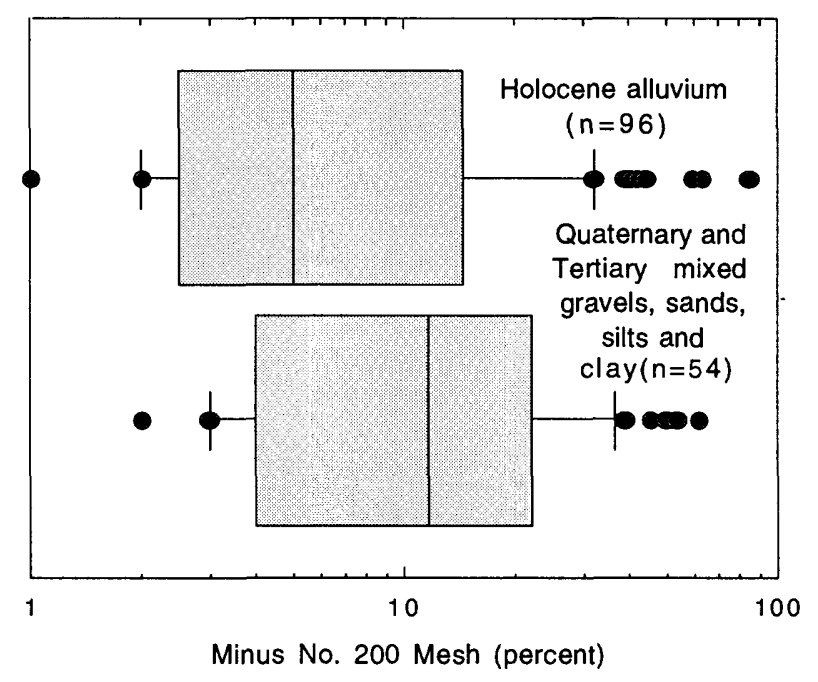

Figure 11. Boxplots of grains passing the no. 200 mesh sieve from observations in Quaternary and Tertiary mixed gravels, sands, silts and clay, and Holocene alluvium. Note values are scale in logarithm base 10. Note that the mesh data are scaled as logarithmic based 10 . 
reject the hypothesis that the medians are statistically identical? A comparison of the medians using the Mann-Whitney $U$ test suggests that the medians are not equal at the 5 percent confidence level. This suggests that Holocene alluvium sites actually have less fines than sites in Tertiary and Quaternary mixed gravels, sands, silts and clay. Holocene alluvial deposits can be expected to be a better source of aggregate in terms of having less undesirable fines. In fact, the chances are three out of four a site in Holocene alluvium contains 15 percent or less fines. Compare this with sites in Tertiary and Quaternary mixed gravels, sands, silts and clay where the odds are three out of five.

\section{Conclusion}

Evaluation of available geotechnical data suggests that overall the Holocene alluvium is likely to be a better source of sand and gravel than the Tertiary and Quaternary mixed gravels, sands, silts and clay with the exception of volume change (see above). While a valuable first step, this study gives just part of the needed information to determine how likely a geology unit will or will not be suitable as a source of aggregate. The study needs to be updated using more and current data.

\section{Source Rock geology}

\section{Introduction}

AHD (1972) and ADOT (1975) sought to determine the quality of sand and gravel deposits by examining what types of bedrock are found in the watershed where they are situated. Weathering and erosion can be both a blessing and a curse in terms of making desirable sand and gravel deposits. Both physical and chemical processes will modify the material if introduced into the alluvial systems. Both may destroy undesirable minerals but may form other materials or other characteristics equally undesirable.

The summary that follows gives general characteristics of alluvium in basins developed along streams from various bedrock units as described by the AHD (1972) and ADOT (1975). Pennsylvanian and Permian rocks are particularly complex and have been variously subdivided and grouped (Weir and others, 1989). As many basins and watersheds contain a mix of bedrock lithologies, the alluvium will have a mixture of qualities.

The PNF area has been described using a large number of geologic formations and contains a wide range of lithologies. However, the consolidated bedrock of the PNF area can be grouped broadly as Cenozoic volcanics, Paleozoic sediments, and Proterozoic rocks.

\section{Cenozoic volcanic rocks}

Volcanic rocks are abundant in the Verde RD but scattered outcrops can be found in all other parts of the PNF as shown on the Conway map. The 
Bradshaw RD has the smallest amount of Cenozoic volcanic rocks. Volcanic rocks, particularly those that are more basaltic in composition, weather to form clays and make a poor source of sand and gravel. Basalt is particularly prevalent in the Verde RD but scattered outcrops are also present throughout the PNF. In contrast, weathering and erosion of silicic volcanic rocks can make a good quality sand and some gravely sand but coarse material are likely to be absent and gravel-rich deposits are uncommon. However, few silicic volcanic rocks outcrop in the PNF.

Basalt has been, and will continue to be, a source of crushed stone where it is found in abundance and other materials are in short supply. See Bliss (1997) assessment of the Coconino NF for a detailed discussion concerning some of the issues of producing aggregate from basalt. Perhaps the single most important rule of thumb concerning basalts is that the younger the better. Few young basalts are found in the PNF compared to basalts found in the adjoining Coconino NF and Kaibab NF. Best basalts for aggregate are glass free (glass reacts with portland cement), have few olivines, have not been subject to hydrothermal alteration, and are fine grained. Bliss (1997, fig. 4) prepared a preliminary model of Los Angeles abrasion test results of basaltic rocks using data from Arizona and New Mexico. All values were less than 40 percent which is a common maximum in standards for material used as aggregate. However, unconsolidated cinders, clinkers and other unconsolidated basaltic materials can have much higher Los Angeles abrasion test results. Over half the observations exceeded 40 percent (Bliss 1997, fig. 5).

Rhyolites are present, if not common, in the adjacent Coconino NF and Kaibab NF. Rhyolites are even less notable in the PNF but limited outcrops may be present. Rhyolites and related extrusive rocks can make good quality aggregate if they contain little glass. Flow-banding may be problematic in crushing as it can result in undesirable elongated fragments (Smith and Collis, 1993). Platy jointing can occur in smaller intrusive bodies and result in undesirable slabs during crushing. Jointing helps make rhyolites easier to quarry but may also generate oversized blocks requiring boulder blasting. Bliss (1997, fig. 6) developed a preliminary model of Los Angeles abrasion test results for intermediate to silica-rich lithologies found in New Mexico.

\section{Paleozoic Rocks}

Paleozoic age rocks are widespread in the two halves of the Chino Valley RD-one northwest of Prescott and the second northwest of Clarkdale as shown on the Conway map. Paleozoic rocks include the Permian Kaibab limestone, Coconino Sandstone, and Permian and Pennsylvanian Supai Formation, Mississsippian and Devonian Redwall and Martin Limestones. Most of the these rocks weather into sand and silts usually unsuitable for use as aggregate. The most promising watersheds in Paleozoic rocks will be those dominated by the Redwall and (or) Martin Limestones that may have good- 
quality sand and gravel given absence of clays. Joint spacing in these carbonate rocks is one factor controlling material size and quantity in the streams.

Crushed stone resources in the Paleozoic rocks is not promising. In general, most sandstone units found in Arizona do not meet abrasion requirements and are not usable in asphalitic concrete (Langland, 1987). Aggregate might be produced from conglomerates that are found with some of the sandstones. One example is the basal Cambrian Tepeats Sandstone. Intermittent outcrops are found in the Black Hills RD and in both the east and west half of the Chino RD. Pebbles up to $3 \mathrm{~cm}(2 \mathrm{inch})$ are present at the base conglomerates which vary in thickness between 0 and $6.7 \mathrm{~m}(22 \mathrm{ft})$ (Krieger, 1965). The lower Tepeats is a massive crossbedded cliff forming sandstone with siliceous cement and described as hard and fairly fractured (AHD, 1972). Several issues need to be resolved. Do the conglomerates have adequate quantity? Do they occur in amounts justifying extraction? Can they be readily quarried?

Limestone is a common source of aggregate wherever it is found. Carbonate rocks of the Mississippian Redwall Limestone are likely one of the better future sources of crushed rocks in the PNF area. Carbonate rocks commonly crop out as cliffs consisting of massive limestone, about half of which consist of dolomite. Mineability may be an issue, considering the nature of outcrops. Impurities, including chert and shale beds, may be problematic in its use as aggregate. The Devonian Martin Limestone consists mostly of dolomite that may be suitable as a crushed stone aggregate if not too reactive. Impurities include thin shale beds. Another unit which contains carbonate rocks is the Kaibab Formation that is 70 percent or more calcium and magnesium carbonates (Langland, 1987). Kiersch (1955) reports that blocky limestone beds in this unit have provided good quality riprap.

Carbonate rocks are not without problems when used as aggregate. However limestones consisting of about equal parts dolomite and calcite that are used as aggregate in cement are more likely to have alkali-carbonate reactions that may destroy concrete competency (Marek, 1991). Carbonate rocks, particularly when fine grained, develop a polishing during road use (Langland, 1987). Carbonate rocks are less problematic in this regard if the insolubles are 10 percent or greater (White, 1991). However, new specifications for high quality pavements like that those associated with Superpave completed by the Strategic Highway Research Program (SHRP) may make some currently acceptable carbonate aggregate unsuitable (Langer and Jahn, 1996).

\section{Proterozoic rocks}

Early Proterozoic rocks are predominantly found in the Bradshaw RD. Scattered outcrops are also found throughout the PNF as shown on the Conway map. These rocks also host a number of Late Cretaceous intrusive granite to diorite rocks in the Bradshaw RD and are included here as well. A 
few outcrops of early to late Proterozoic porphyritic granites are also present in Bradshaw RD and are notable for being relatively undeformed. Lithologies of Early Proterozoic rocks include basalt, rhyolite tuffs, andesites, gabbro, diorite, granodiorites, alaskite, diabase, quartz diorite, tonalite, granite, and various sedimentary rocks including argillites (Mohammed and others, 1995; Krieger, 1965). Previous deformation and metamorphism of these older rocks can add undesirable properties. For example, schistose fabric rocks weather to produce platy, often fissile debris, unsuitable as aggregate. Better quality sand and gravel can be expected in watersheds with granites, however contamination for other metamorphic rocks may be a problem. For example, schist tends to generate soft fissile material of poor quality for use as aggregate. Gabbroic dikes are also observed. Some are associated with Proterozoic granites. They appear to weather to form durable cobbles in some streams of the Bradshaw RD (Ed Dewitt, verbal commun, via Eric Force, 1997) and may be elsewhere in the PNF as well.

Proterozoic rocks and associated Late Cretaceous intrusive granite to diorite rocks may represent a significant future aggregate resource in the PNF. They will require careful evaluation. However, optimism needs to be tempered with the recognition that there are a number of factors likely to make these rocks less desirable as sources of crushed rock. Metallic mineralization overprints in the Bradshaw RD and elsewhere will also be problematic since sulfides and associated alterations are undesirable in aggregates. Some Proterozoic rocks may have been exposed at the surface for long periods. Weathering may have been extensive and deep. This may make the rocks potentially less suitable for aggregate. Most of the Proterozoic rocks have been effected by regional metamorphism that produces foliation that may not be necessarily visible to the naked eye (Smith and Collis, 1993) or it may be visible as a platy texture. Crushing these types of rocks may generate aggregate with preferred alignment and may give roadways undesirable preferred directions of weakness or anisotropism (Smith and Collis, 1993). Platy fragments may align in wear surfaces reducing friction. High grade metamorphism, particularly where partial melting and recrystallization has occurred, will remove undesirable foliation and produce gneiss. However, care needs to be taken when considering using quartz-bearing metamorphically deformed rocks as aggregate. They may expand due to alkali-silica reaction (Thompson and Grattan-Bellew, 1993). These rocks can be massive and granular and may be found to be a good source of crushed rock (Smith and Collis, 1993). Massive quartzitic rocks may or may not be present in the PNF area. However they are another type of rock to be sought as source of aggregate in high-grade metamorphic terrane (Smith and Collis, 1993).

Fine-grained Proterozoic basic volcanic rocks (gabbros and diabases ) may also be sought. As noted in Brattli (1992), mean grain or mineral size of basic igneous rocks has the strongest effect on mechanical rock character. The effect is best seen when grain size is less than $1 \mathrm{~mm}$. Metamorphism appears to reduce strength properties of basic igneous rocks (Brattli, 1992). One control 
of mechanical properties is related to the presence of cracks and flaws (or holes) found both along grain boundaries and within the minerals. Most cracks have lengths "usually $1 / 10$ the grain size" (Brattli, 1992, p. 37). Some dense gabbros and diabases can be nearly crack-free (Spunt and Brace, 1974) which likely improves their quality for aggregate. Rocks with smaller grains can also be expected to have shorter cracks which contributes to better mechanical strength. Microcracks may also play a role in the behavior of granitic rocks as well (Baek, 1997).

\section{Iron oxides as an industrial mineral}

\section{Introduction}

Iron oxide is the only major colored mineral that can be used as a pigment (Podolsky and Keller, 1994). In fact, it may well have been one of the first pigments used by humans. Iron oxide pigments are desirable for use because they are non-toxic, non-bleeding, relatively inert, weather resistant, comparably opaque and resistant to changes from light exposure (Harben, 1995). Iron oxides are comparable to other industrial minerals in that their chemical and physical properties are keys to their use. Iron oxide have the capacity to absorb oil. Other properties of iron oxides effecting how they are used include: particles surface area, particle size and the distribution of sizes of iron oxide particles, their shape and the interrelationship all previously listed characteristics have on optical behavior (Harben, 1995).

One trend is the increasing use of synthetic iron oxides in place of natural iron oxides. Synthetic iron oxides are compositionally more consistent as well as having superior physical and chemical properties when compared to natural iron oxides (Harben, 1995). Podolsky and Keller (1994, table 6) using U.S. Bureau of Mines data shows that the tonnage of natural iron oxide production has slipped from 41 percent in 1970 to 38 percent in 1990. The change is even greater in terms of value. The value of natural iron oxide production has dropped from 21 percent of the total in 1970 to 10 percent in 1990 (Podolsky and Keller, 1994).

Hematite is the most important natural source of iron oxide for use as pigments (Podolsky and Keller, 1994). It is particularly sought for its use as a red pigment; other natural minerals used for this include calcined siderite, and calcined pyrite (Podolsky and Keller, 1994). Calcination is a process where a mineral ore is heated to a temperature were it undergoes a chemical breakdown.

\section{Sources of iron oxide in the PNF}

Iron oxide has been mined at the Seligman (Juniper Mountains, Cowden) hematite district $\left(35^{\circ} 06^{\prime} 00^{\prime \prime} \mathrm{N}, 112^{\circ} 52^{\prime} 48^{\prime \prime} \mathrm{W}\right)$. Mining claims are found in sections 15, 21-23, 26, and 27, T20N, R6W (Harrer, 1964; Klemic, 1969). 
Mineralization is hosted by the Redwall Limestone. This location is within the Chino Valley RD of the U.S. Forest Service (1993). Welty and others (1989) describe the mineralization as a number of stratiform bodies, consisting of red to bluish black hematite. They form lenticular contact pyrometasomatic replacement bodies 0.6 to $12 \mathrm{~m}$ ( 2 to $40 \mathrm{ft}$ ) thick adjacent to a andesite porphyry sill (Harrer, 1964). Some bodies are as long as $300 \mathrm{~m}(1,000$ $\mathrm{ft}$.) Mineralization is clearly suggested for more than a half mile along the Walnut Creek road that traverses the deposit.

The deposit was worked for hematite for use as mineral pigment. Grades of material reported by Harrer (1964) for 11 samples are between 56 and 61 percent Fe and have a mean of 62 percent (fig. 12). Samples 1, 2, 4, and 5 (Harrer, 1964, table 26) were collected from 3.3, 4.6, 1.5, and $1.5 \mathrm{~m}(15,20,5$, and $4.8 \mathrm{ft}$ ) thick horizons respectively and have a mean Fe content of 62.1 percent weighted by bed thickness.

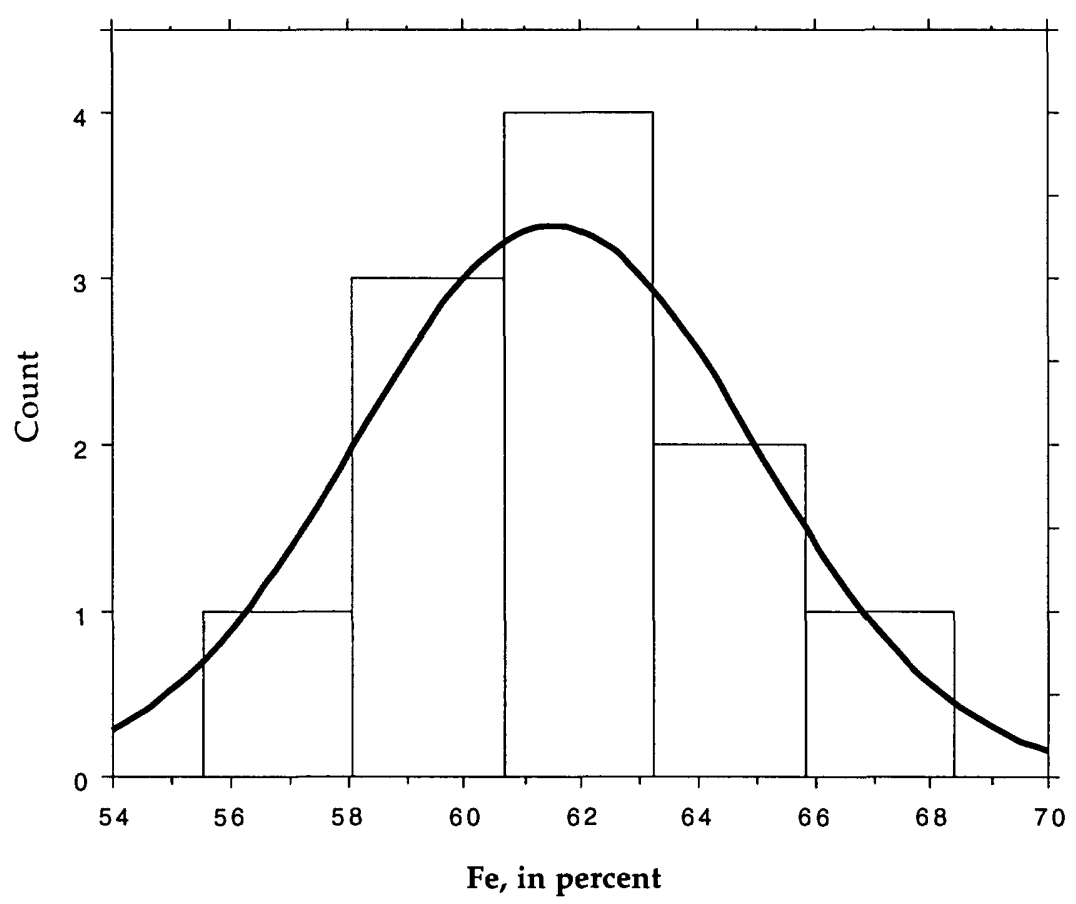

Figure 12. Histogram and fitted normal curve of Fe grades for 11 samples of the Seligman (Cowden) hematite deposit.

Phillips and others (1998) report that one mine in the district (the Iron Chancellor Mine) is now active. The mine is worked as an open pit and under ground for hematite pigment. Processing involves grinding and sizing of a iron oxide pigment which is blended with synthetic iron oxide pigments for use in paints, plastics, concrete products and as a mold release in casting (Phillips and others, 1998).

Podolsky and Keller (1994, table 1) gives three examples of hematite compositions suitable for use as pigments from production in the US, Spain 
and the Persian Gulf. Fe content in these examples are between 44 and 60 percent Fe. This suggests that the hematite content of the Seligman iron deposit is likely still acceptable for use as pigment in terms of Fe content.

Trace elements allowed in pigmentation of pet foods include the

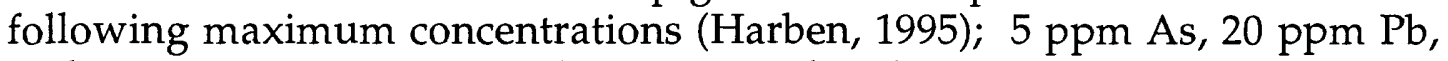
and $3 \mathrm{ppm} \mathrm{Hg}$. For use in pharmaceutical and cosmetics, the following

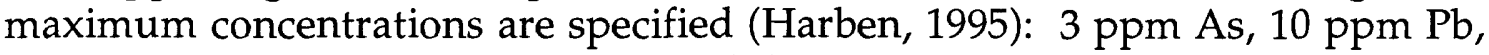
and $3 \mathrm{ppm} \mathrm{Hg}$. In most materials both heavy and toxic elements are found in complex silicates. The Food and Drug Administration has rated iron oxides as generally safe (Harben, 1995). The Seligman hematite deposit may have a problem in terms of too much trace metal content. Harrer (1964) reports that some metals have concentrations "as much as" $100 \mathrm{ppm}$ percent $\mathrm{Pb}, 300 \mathrm{ppm}$ $\mathrm{Zn}, 1,600 \mathrm{ppm} \mathrm{Cu}, 500 \mathrm{ppm} \mathrm{As}, 1,000 \mathrm{ppm} \mathrm{Ti}, 100 \mathrm{ppm} \mathrm{Mo,} 50 \mathrm{ppm} \mathrm{Cr}$, and 50 $\mathrm{ppm}$ V. The ability to fabricate synthetic iron oxides with low levels of heavy elements has been key popularity in replacing of iron oxides from natural sources. Typical content of natural red pigment (Podolsky and Keller, 1994, table 9) is as follows: $50-100 \mathrm{ppm}$ As, $40-80 \mathrm{ppm} \mathrm{Sb}$, less than $50 \mathrm{ppm} \mathrm{Cd}$, less than $20 \mathrm{ppm}$ Se, less than $5 \mathrm{ppm} \mathrm{Hg}, 6,000$ plus ppm $\mathrm{Pb}$ and 100 to 2,000 ppm Ba.

\section{Comparable sources of iron oxide in northern Arizona}

Two other occurrences of hematite are noted in northern Arizona. These may or may not be comparable to the Seligman district. This includes iron occurrences in the Grand Wash Cliffs, Mohave County described by Schrader (1909) and located by Harrer (1964) in the northern half to T26N and R13W and R14W, 18 miles north of the town of Hackberry. Schrader (1909) describes the iron as situated in carboniferous limestone with local copper staining. The second occurrence is about 20 miles northwest of the Seligman hematite district and located by Harrer (1964) is in the SE quarter, section 16, T22N R8W near Markhams Well, Yavapai County. The occurrence includes hematite, jasper and white quartz replacement in Paleozoic limestone in a zone $30 \mathrm{~m}$ $(100 \mathrm{ft})$ wide and traced for more $300 \mathrm{~m}(1,000 \mathrm{ft})$ (Harrer, 1964). However, Harrer (1964) suggests that mineralized bodies here are erratic and that working the deposit would require sorting. The iron content of a characteristic sample is 36 percent (Harrer, 1994).

\section{Permissible geology}

All parts of the Redwall and Martin Limestones are permissive for undiscovered iron oxide deposits. The presence of an intrusive body like the one seen at Seligman is likely necessary. However, it may not be seen in outcrop. 


\section{Cat-litter}

\section{Introduction}

Material has been extracted in the PNF area that was thought to be suitable for cat-litter. In reality, it was not. Because most geologists and explorationists are likely unfamiliar with cat-litter fabrication, a more expansive discussion is included here. What materials are used in cat litter? What properties must they have? What is the prognosis for future demand for cat-litter? What type of geology in the PNF area is more likely to contain material suitable for cat-litter?

\section{Background}

Austin and Mojtabai (1996) report there were about 63 million cats in the US as of 1992 and their numbers continue to increase. The demand for materials suitable for cat-litter is increasing. Desirable material must control odor and be as dust free as possible. Cat-litter manufacturers also continue to seek to develop and market new products in the highly competitive cat litter market. For example, one development is for cat-litter to interact with cat waste in a way to make the material easily scoopable. This means cat litter must behave in very specific ways. Consequently, these types of requirements may also reduce the number of natural materials that can used in cat-litter fabrication.

\section{Material properties}

Material suitable for cat-litter has properties related to the following characteristics:

absorption

odor control

bulk density

granule size

granule shape
formation of dust
strength
safety

longevity

color (see section on Marketing issues)

disposal methods

Absorption and odor control are the two principle characteristics catlitter must have. Absorption is dependent on the porosity, permeability, and surface area of the material used and the chemistry of cat waste. Most odor is related to fermentation of urea to ammonia. Absorption of ammonia by the litter is the best way to control odor.

Bulk density is of concern in litter performance as well as in marketing. Light-weight litter reduces shipping and related costs; however if it is too light weight it may also be easily kicked from the litter box during use. Austin and Mojtabai (1996) note that clever marketing has essentially made any bulk density a favorable litter property.

Granule size and sharpness are important as they relate to trackability. Grains that stick to cat paws find their way outside the litter box. Grains need to as round as possible to prevent this from happening as well as to insure 
litter is safe for use and to prevent damage and leakage to litter packaging during shipping (Austin and Mojtabai, 1996).

Litter strength, formation of dust and safety are related issues. The material needs to have sufficient strength to resist formation of dust during shipping and during cat use. Formation of dust needs to be at a minimum. Dust also can be inhaled by cat and owner. Dust and poor odor control are the leading complaints made by customers. Product dust may be one problem; so is the presence of bacteria on dust grains developed once litter has been used (Bob Virta, written commun., 1997).

Inhalation of airborne opal grains possibly found in some cat litter is one of several minerals of potential health concern. Asbestos-like fibers were reported to have been found in seven different cat litters in West Germany. Later the West German Federal Health Office found the litter harmless (Austin and Mojtabai, 1996) but perception can be hard to change and the ideathat cat litter may be a health risk can have significant negative market effect. Producers need to diligently insure that cat litter is safe for both animal and human.

How long will a cat continue to use (and owners to tolerate) litter before it needs to be changed? Litter needs to repeatedly coat feces, absorb urine and odor, and withstand cat traffic without breaking down and forming dust. Scoopable litter is marketed as one which will encapsulate cat waste for ease of removal. The litter never needs to be replaced. The owner need only replenish as litter is depleted. Scoopable litter should result in an overall reduction of litter volume required in annual cat waste management.

Cat-litter is commonly disposed with household trash or is flushed. Some sewage operations have rules prohibiting the disposal of animal waste in community sewage treatment systems. However, this does not prevent some litter producers from advertising that their litter can be safely flushed. Litters are more likely to be a problem in sewage treatment plants if they contain swelling clays (Austin and Mojtabai, 1996).

\section{Mineral cat-litter materials}

Most cat litters are predominantly mineral. They can be grouped as heavyweight clays, lightweight clays, and non-clays (Austin and Mojtabai, 1996). A number of organic materials are also being used and are noted elsewhere. Heavyweight clays have densities from 800 to $980 \mathrm{~kg} / \mathrm{m}^{3}$ and include fuller's earth and sodium bentonite. Lightweight clays have densities from 400 to $700 \mathrm{~kg} / \mathrm{m}^{3}$ and include sepiolite, and palygorskite/attapulgite. The primary non-clay industrial mineral used in cat litter is the zeolite mineral, clinoptilolite. Hydrated calcium silicate is used in Europe; other cat litters use materials derived from gypsum. A material called "moler" after calcination is produced in Denmark as litter. The moler clay consists of 75 percent diatomaceous earth, 23 percent montmorillonite, and 2 percent volcanic ash. 
Usually cat litters do not contain a single clay type or material but are blends of materials where both the material and processes used in preparation may be a closely guarded corporate secrets. Nearly all litter also contains perfumes and colorants (Austin and Mojtabai, 1996).

Heavyweight clays are about 50 percent more absorbent than lightweight clays (Austin and Mojtabai, 1996). However heavyweight clays are more expensive to ship than lightweight clays and heavyweight clays used in litter is declining (Austin and Mojtabai, 1996). Heavyweight clays include fuller's earth that consists of calcium bentonite, acid-activated illite, and some palygorskite/attapulgite. In Europe, fuller's earth is more calcium bentonite rich; it is produced in the UK from pits worked since Roman times. One type of heavyweight clay that is likely to undergo increased demand is sodium bentonite--a swelling clay important in manufacturing scoopable litters-much of which is produced in Wyoming (Austin and Mojtabai, 1996). Bentonite and fuller's earth are the two major clays used and are found in over 95 percent of the clay cat litter absorbents marketed (B. Virta, written commun., 1997).

Lightweight clays include attapulgite and sepiolite which have needleshaped crystals unlike flaky bentonite and platy kaolin. It is the crystal shape of lightweight clays that has raised inhalation health concerns. Unlike the widely available heavyweight clays, lightweight clays tend to be relatively rare. About 74 percent of sepiolite and palygorskite/attapulgite production capacity in the US is from Georgia and Florida (Harben, 1995); Spain is a source of additional sepiolite (Austin and Mojtabai, 1996). A significant portion of the palygorskite/attapulgite produced is used in cat litter manufacture (Clarke, 1985, as cited by Austin and Mojtabai, 1996).

Zeolites are the main non-clay material used in cat litter. Other nonclay material include hydrated calcium silicates and gypsum. Zeolites' structure provides a very large surface area per unit weight important for odor absorption--up to $60 \mathrm{~m}^{2}$ per gram (S. Peterson, Zeotech Corporation, verbal commun., 1993, to Austin and Mojtabai, (1996))

\section{Possible sources of cat-litter in the PNF area}

\section{Volcanic tuff}

Volcanic tuff near Kirkland, Arizona at a site identified as Cat's Pause (Phillips, 1987) was quarried for use as building stone. Later, it was crushed and rolled to make cat-litter. However, the resulting product was of poor quality notable for excess dust, so production was discontinued 10-15 years ago (Ken Phillips, Arizona Division of Mines and Geology, verbal communications, 1997). Since volcanic tuff has been abandoned, what, then, are the materials likely found in the PNF area that may be used in cat-litter? 
Cat-litters are predominately clays. the amount of clay possibly suitable for this use in the PNF area are largely undefined. Clay deposits are also the product of diverse processes including alteration products of hydrothermal systems, and surficial weathering (Harben and Kuzvart, 1996). Clays are also found in sedimentary rocks, including those associated with both marine and lacustrine environments. Clay's genetics can be complex. Hydrothermal systems have operated in the PNF as testified by the extensive number of metal deposits found in the area. The type and extent of the associated clay deposits (if any) are not clearly known to me. One example of the type deposit which may occur is that of a kaolinite deposit developed from hydrothermally altered volcanic rocks near Globe, Ariz. (Phillips, 1987). A review of alterations associated with metal deposits in the PNF area might locate similar deposits. How suitable these deposit are as cat-litter is unknown.

Description of clay occurrences usually give little mineralogical information so it is unclear if a given deposit is worthy of consideration for cat-litter. Clay production has occurred from the Verde Formation of Pliocene and Miocene ages (Weir and others, 1989) particularly in the area of Clarkdale and Camp Verde (fig. 1). Clays at Clarkdale are used in cement fabrication (Phillips, 1987). their suitably for cat-litter is unknown. Clays produced from the Larson quarry (Phillips, 1987) near Camp Verde were described as bentonitic and used in iron ore palletizing and as canal-reservoir sealer. Other bentonitic clays have been produced as a byproduct of thenardite, mirabilite, and gyspum production from the Verde Formation. Funnell and Wolfe (1964) as cited by Lane (1992) noted that low-expanding, high-calcium montmorillonite is also found southeast of Camp Verde (fig. 1). Clays were also produced as byproduct of gypsum at the Verde Gypsum site (Phillips and others, 1998). they was used as a sealer for ponds, and ditches. See Lane (1992, table 1) for the chemical and physical characteristics of some clay samples collected in the Verde Formation. The Verde Formation is perhaps the most likely one to contain clays which may be suitable as cat litter.

A number of other sites have been identified with clays. The geologic details about these sites is not readily available nor it is known how suitable they may be for use as cat-litter. This includes sepiolite, a light weight clay used in cat-litter (see above), with magnesite at a unnamed site in the Squaw Creek Mesa 7.5' quadrangle (Phillips, 1987), southeast of the Bradshaw RD (fig. 1). The geologic situation is unknown. Two sites are noted east of Prescott in the Prescott Valley South 7.5' quadrangle (Phillips, 1987); both are for clays used to manufacture vitreous clay pipe. Phillips and others (1998) notes that one site--the Dewey Ranch \#2 operation--9.6 km (6 mi) north of Dewey (fig. 1) is active in the production of vitreous clay permanent sewer pipe. The pit is located in either the Tertiary and Quaternary mixed gravels, sands, silts and clays or the Miocene sedimentary rocks as shown on the Conway map. An 
active open pit is also found about 16 to $19 \mathrm{~km}$ (10 to $12 \mathrm{mi}) 1$ northwest of Kirkland (fig. 1) that produces hectorite clay used as a viscosifier and thickener in pharmaceuticals and cosmetics (Phillips and others, 1998). The local geologic situation is unknown but the site is found in the Tertiary and Quaternary mixed gravels, sands, silts and clay of the Conway map.

Based on preliminary and very sketchy information, this study suggests that bentonitic clays are the more likely type to be present in the PNF area which may be suitable for cat-litter. The Verde Formation appears to be the most promising. Some of the clays in the Verde Formation have developed from in situ argillic alteration of volcanic ash in an alkaline lacustrine environment. Hydrothermal springs in the basin may have been present which can also result in clay development (Harben and Kuzvart (1996).

\section{Gypsum}

Gypsum is a smaller component of cat litter and is a material also recognized in the PNF area. Lacustrine gypsum is found in the Verde Formation of Pliocene and Miocene ages (Weir and others, 1989) in the Verde River Valley that begins in the northwest in the Chino Valley RD down to Camp Verde and beyond to the southeast (Fig. 1). See the section on gypsum beginning on page 35 for additional details.

\section{Zeolites}

Zeolites, as noted above, are the main non-clay ingredient in cat-litter. Hay $(1978,1981)$, as noted by Harben and Kuzvart (1996), suggests that there are six major geologic environments for zeolite development. They include: saline alkaline lakes (an example includes Tecopa Lake, California), weathered zones particularly of saline or alkaline soils (an example includes San Joaquin Valley, California), deep-sea sediments, open hydrologic systems, hydrothermal or hot springs, and burial metamorphic.

Harben and Kuzvart (1996, p. 449) suggest the best type of rocks in which to search for zeolites are "altered ash-fall and ash-flow tuffs or tuffaceous sediments of Tertiary age." In fact, the tuff crushed for cat-litter near Kirkland was recognized as containing clinoptilolite, a zeolite mineral. Note that this is the zeolite mineral commonly used in cat-litter (see above). Altered tuffs are found in the Verde Formation of Pliocene and Miocene ages (Weir and others, 1989). They also contains phillipsite, a zeolite mineral (see Table 5). Note that this zeolite mineral is not one commonly used in catlitter. To the east of the PNF, Miocene rhyolite and rhyodacite (near the confluence of the Verde and east Verde Valley rivers including Clear Creek) are described as air-fall tuff and tuff breccia that are interbedded with Miocene basalts between 0.5 and $5 \mathrm{~m}(2-15 \mathrm{ft}$ ) thick (Wrucke and Conway, 1987; Weir and others, 1989). Tuffs are also recognized west of the PNF area in the Wilder Formation (Anderson and others, 1955) in the area around Bagdad, Ariz. that is described as consisting predominantly of Miocene sedimentary 
rocks generally described as valley fill. Therefore, zeolites in altered tuffs, both recognized and undiscovered, are possible within the extensive areas of Tertiary volcanic rocks in the PNF area.

\section{Marketing issues}

Cat-litter consumption is a stable industrial-mineral market (Austin and Mojtabai, 1996). It is also growing at about 6 percent annually (Santarén and Alvarez, (1994). The unit-value of cat-litter is sufficiently high that some is marketed globally. European markets are dominated by lightweight clays (O'Driscoll, 1992 ). Europeans also prefer cat litter that is light colored as do most consumers in the US. Color can be a marketing issue of surprising importance. In Denmark a pink litter is sold. Gray is preferred in the United Kingdom. Light-colored litter is also preferred by veterinarians who use cat urine color in diagnosing a possible indication of disease. Light-colored litter is also perceived to be more antiseptic by some consumers. Some litters have a few blue-dyed granules that suggest additional potency perhaps comparable to the marketing strategy used to advertise certain laundry soaps (Austin and Mojtabai, 1996).

Cat litter is not inexpensive but it appears not to have increased in price in the last several years. A survey of 13 retail prices were made in Socorro, New Mexico in 1994 by Austin and Mojtabai (1996). A similar survey was made in Tucson, Arizona in 1998 of 31 cat litters. Comparison between the two surveys is made using boxplots (fig. 13) where retail prices are expressed as dollars per metric ton $(\$ / t)$. See figure 2 for a discussion on boxplot layout.

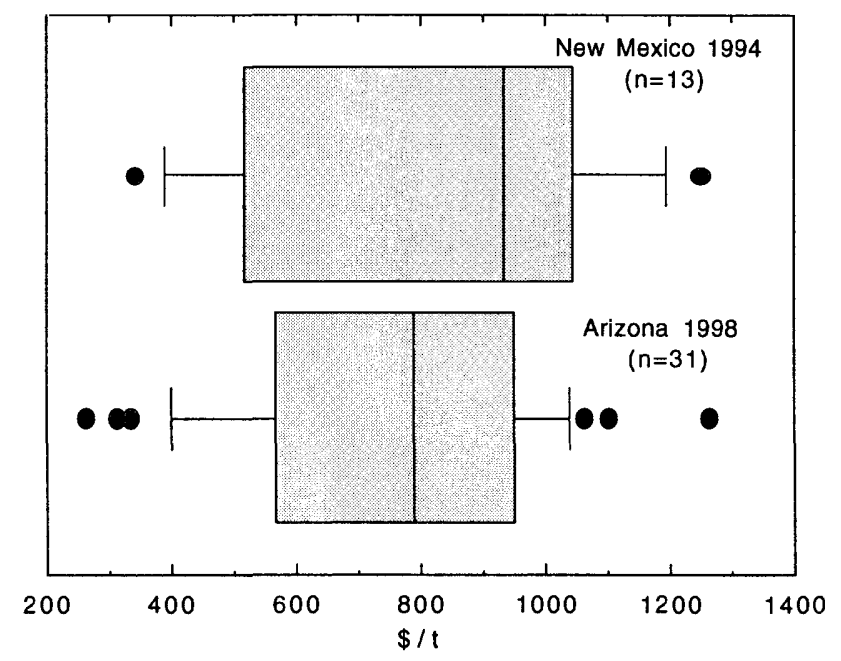

Figure 13. Comparison of retail values of cat litter prices ( $\$ / t)$ in Socorro, New Mexico in 1994 to those in Tucson, Arizona in 1998. 
Prices of the New Mexico cat litter survey have also been adjusted to account for inflation using 1997 dollars. The median value of cat litter prices in the 1998 Tucson survey was $\$ 787 / \mathrm{t}$--the median price, adjusted for inflation, of the 1994 Socorro survey is $\$ 932 / \mathrm{t}$. This represents a 15 percent reduction in price. This translates to about $\$ 1.60$ reduction in price for a 25 pound bag of cat litter. However, the price spread in both surveys when shown as boxplots overlaps almost completely (fig. 13). Can the assumption that the medians are not equal be rejected? The nonparametric Mann-Whitney $U$ test used to compare the prices per ton in the two surveys suggests that the assumption that the medians are actually identical could not be rejected at the five percent confidence level. This suggests that the price of litter has been unchanged. This may be due to reduced demand or more likely the presence of highly competitive companies in this market.

The Tucson survey also revealed that cat litter prices have a bimodal structure that can readily be seen as double peaks in a histogram plot (fig. 14).

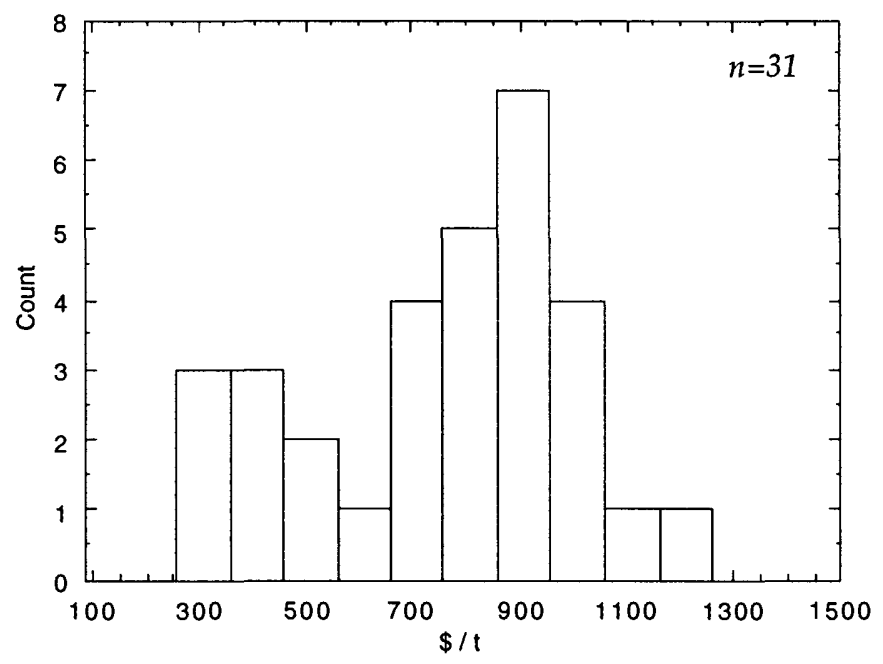

Figure 14. Histogram of 31 cat litter prices for sale in Tucson in 1998.

The left peak with prices in the range of $\$ 300$ to $\$ 600 / t$ is for customers who are concerned primarily with low price where litter is sold in small and larger bags for volume discounting (up to $50 \mathrm{lbs}$.) Litter packaging includes paper bags and small to medium tubs. The scatter bivarite plot of price and weight reveals that low prices can be found for all sizes of litter packaging (fig. 15). 


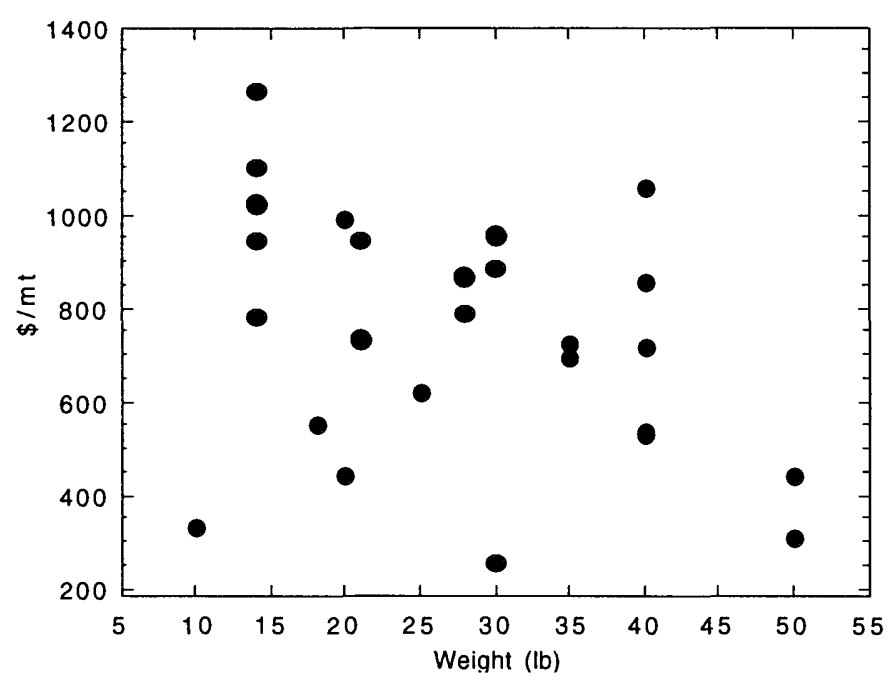

Figure 15. Bivariate scatterplot of cat litter package weights (lbs) and prices $(\$ / t)$ in Tucson, Arizona in 1998.

While the two largest sized litter bags ( $23 \mathrm{~kg}$ or $50 \mathrm{lbs}$.) have low unit prices, there is no strong relationship between weight and unit price (fig. 15).

Packaging weight tends to be in increments of five or ten pounds which makes for a spiky histogram (Fig. 16); the median weight is $13 \mathrm{~kg}$ (28 lbs.)

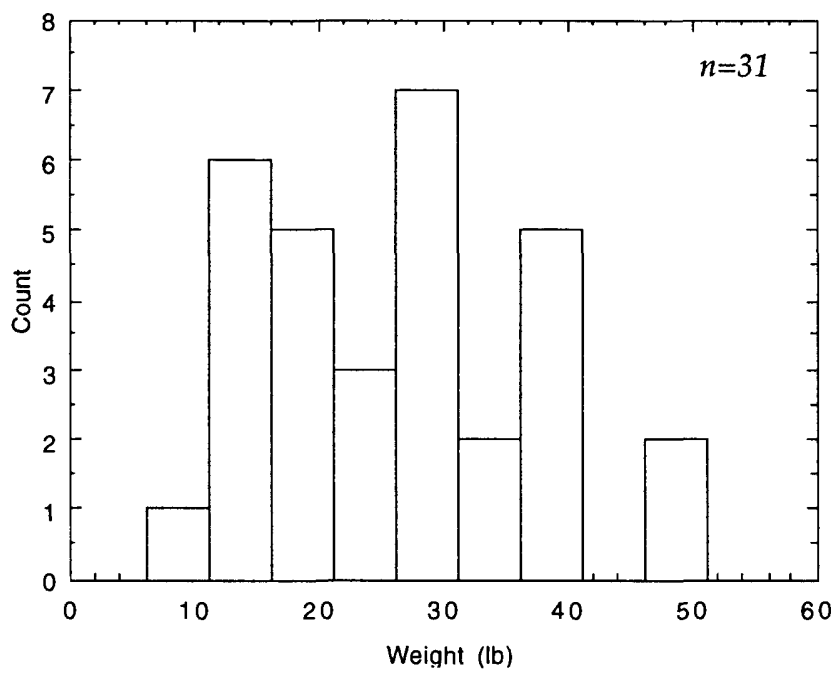

Figure 16. Histogram of package weights of 31 cat litters for sale in Tucson in 1998.

Trends in the Tucson survey also found wide availability of scoopable litters. Some cat litters were antibacterial and contained baking soda or activated charcoal for odor control. Two litters in the survey were made of pine sawdust one of which was advertised as "silica free." One litter consisted 
of wheat and milo; another was made of recycled newspapers. Prices of these organic-type litters were all above the median and represented about 10 percent of the litters surveyed in Tucson. This is comparable to the 1994 survey in Socorro, NM where one out of the 13 litters was organic--consisting of alfalfa and oat hulls (Austin and Mojtabai, 1996).

\section{Landscaping Materials}

Rocks of all types find their way into landscaping. This is increasingly so where developers and home owners seek ways to develop yards and roadways which appear compatible with surrounding environment and have landscapes with low water requirements. Others seek to develop rock gardens. Stones and rock surfaces can be aesthetically pleasing yet require no water and much less upkeep. Positioned correctly, rocks can be used to collect rain, concentrating the water into a number of mini oasises for existing plants. Some people seek simple landscape surfaces without much vegetation. Consumers use decomposed granite for this purpose.

Landscaping materials are found at several exposures in the PNF area (Eric Force, written commun., 1997). Three operations are noted by Phillips and others (1998) that are scattered in a six to seven square miles area 3 to 5 miles east of Dewey (fig. 1) adjacent to the Verde RD. Two sites are described as granite quarries producing landscape material or as producing decomposed and crushed granite for desert landscaping. The bedrock appears to be Early Proterozoic quartz diorite on the Conway map. The third site is described as a pit producing decorative boulders and screened material likely extracted from alluvium. Some flagging material from the Coconino Sandstone found in, and north of, the Chino Valley RD (fig. 1) is also customized and marketed as specialty landscape shapes (Phillips and others, 1998). Demand for landscaping materials can be expected to increase with the continued population growth in the surrounding area. 


\section{Part II: Selected Geologic Setting of Industrial Minerals}

\section{Industrial minerals from marine and lacustrine deposits}

[Note: this section from Bliss (1997) is applicable also to the PNF and has been modified for use here. Lithologies discussed below are separately covered in the section on aggregate.]

\section{Carbonate rocks}

The primary use of carbonate rocks in the PNF area is in the fabrication of cement and lime. They are also crushed for use as aggregate in construction. Limestone and calcareous rocks make up 75-80 percent of the raw material used to make cement (Harben and Bates, 1984). Dolomite is tolerated in limestones up to about 5 percent of the raw material for cement manufacture (Harben and Bates, 1984).

Other uses of limestone or derivative products (e.g., lime) include dimension stone, rip rap, road metal, roofing granules, fillers (paper, asphalt), filters (water treatment), absorbents (gold leaching), ceramics, flux (steel), agriculture, glass, and well drilling fluids (Keith, 1969b; Lefond, 1983). Also see discussion on aggregate in the section on Paleozoic rocks.

In Arizona, the copper industry uses lime in flue gas desulphurisation (O'Driscoll, 1990). Production of limestone for use in cement manufacture is found just east of the PNF at Clarkdale (fig. 1). The Clarkdale Cement Plant limestone quarry not only produces from the Redwall Limestone but also from the Devonian Martin Formation. Lane (1992) notes that the limestone provides the necessary $\mathrm{CaCO}_{3}, \mathrm{SiO}_{2}$, and $\mathrm{MgO}$ (that is in dolomitic lenses in the limestone) needed to manufacture cement. Whole-rock analyses for limestone samples are given by Lane (1992, table 2). Blocky outcrops of Kaibab Formation have provided good quality riprap (White, 1991).

Units in and adjacent to the PNF that have been sources of carbonate rock including the Red Wall Limestone, and Martin Formation. One other source may the limestone facies in the Verde Formation. Three samples of limestone from the Verde Formation were collected by the Bureau of Mines from three different sites (Lane, 1992, plate 3, fig. 3). The analyses indicate they are suitable for use in cement manufacture (Lane, 1992, table 2).

However, the limestones are interbedded with clay and other materials that will make mining difficult. Parts of the Kaibab Formation (when it contains 70 percent or more calcium and magnesium carbonates) are also possibly suitable for use.

The only quantitative model developed so far with some applicability to carbonates in the PNF region is one for Los Angeles wear test using data from a mix of sites from consolidated and unconsolidated materials located on the Kaibab Formation on the Colorado Plateau (Bliss 1997, fig. 7). 
However, the Kaibab has considerable non-carbonate material and the model is more formation specific than lithologically specific.

\section{Gypsum}

\section{Introduction}

The primary use of gypsum is in the form of calcined gypsum $\left(\mathrm{CaSO}_{4} \cdot 1 / 2 \mathrm{H}_{2} 0\right)$ or plaster of Paris that is an important product as a component of plasterboard and accounts for 70 percent of gypsum consumption in the US (Harben and Bates, 1990). Other uses of gypsum is as a retardant in cement; as a fertilizer; as a filler in paper, paint, and toothpaste; and in the production of gypsum muds for oil well drilling (Harben and Bates, 1984). The status of gypsum production in the PNF area was not determined

A quantitative model developed so far with some applicability to carbonates in the PNF region is one for marine gypsum deposits (Orris (1992c, e). Gypsum in the PNF region is found in the Harrisburg Member of the Coconino Sandstone; possibly in some facies in the Kaibab Formation, and lacustrine gypsum in the Verde Formation which may be suitable but are limited in volume.

\section{Background}

Gypsum, or hydrous calcium sulfate $\left(\mathrm{CaSO}_{4} \cdot 2 \mathrm{H}_{2} \mathrm{O}\right)$, is the most abundant naturally occurring sulfate (Harben and Bates, 1990). Upon loss of water gypsum becomes the mineral anhydrite $\left(\mathrm{CaSO}_{4}\right)$. Use of anhydrite is minor when compared to gypsum, although neither mineral is found without the other (Appleyard, 1983). Unfortunately, currently unusable anhydrite represents the larger part of the world's extensive reserves of these sulfates (Appleyard, 1983). Due to the wide availability of gypsum, only readily accessible deposits at the surface are being worked. Strip mining is the common extraction method, with some operations exceeding $50 \mathrm{~m}$ in depth (Raup, 1991). Because transportation is a major contributing cost, proximity to infrastructure and markets is critical in deciding if a deposit will be worked. Gypsum and anhydrite constitute the largest known reserve of sulfur, although it is largely untapped and is currently an uneconomic source.

\section{Geology}

Gypsum and anhydrite occur as evaporites identified in rocks of Silurian age through Quaternary age (Appleyard, 1983). The proportion consisting of anhydrite increases with geologic age of the enclosing rock. Thus, younger deposits are more likely to be worked because they contain more gypsum. Gypsum is commonly found associated with other evaporites. Due to its high 
solubility, primary gypsum deposits are subject to considerable postdepositional modification, recrystallization, and remobilization.

\section{Models}

Two broad types of bedded gypsum deposits are recognized for modeling purposes: marine evaporite gypsum (Raup, 1991) and lacustrine gypsum (Orris, 1992c). Both types have permissive geology in the PNF. The descriptive model by Orris (1992c) suggests that most lacustrine gypsum deposits develop in closed or nearly closed continental basins (usually fault controlled) under semiarid to arid conditions. The descriptive model by Raup (1991) notes that marine gypsum deposits develop from the evaporation of sea water in marginal marine basins.

The preliminary grade and tonnage model by Orris (1992e) for marine gypsum deposits is based on data from 14 entities that include data from a mix of districts, areas, and single deposits. Ninety percent of the deposits have a size equal to or greater than 14 million $t ; 50$ percent have a size equal to or greater than 280 million $t$; and 10 percent of the deposits have a size equal to or greater than 5.6 billion $t$ (Orris, 1992e, fig. 35). Ninety percent of the deposits have a gypsum grade equal to or greater than 82 percent; 50 percent have a gypsum grade equal to or greater than 91 percent; and 10 percent of the deposits have a gypsum grade equal to or greater than 99.8 percent (Orris, 1992e, fig. 36).

The preliminary grade and tonnage model by Orris (1992c) for lacustrine gypsum deposits is also based on data from 14 entities. Ninety percent of the deposits have a size equal to or greater than 0.78 million $t ; 50$ percent have a size equal to or greater than 14 million $t$; and 10 percent of the deposits have a size equal to or greater than 247 billion $t$ (Orris, 1992c, fig. 35). Ninety percent of the deposits have a gypsum grade equal to or greater than 74 percent; 50 percent have a gypsum grade equal to or greater than 85 percent; and 10 percent of the deposits have a gypsum grade equal to or greater than 96 percent (Orris, 1992c, fig. 36). Lacustrine deposits tend to be both smaller and of lower grade than those for marine deposits.

\section{Deposits and tracts}

One unit found in the PNF contains evaporites and is, thus, permissive for marine gypsum deposits--the Permian Coconino Sandstone. The Toroweap Formation is commonly included with the Coconino Sandstone.

It is the Harrisburg Member of the Coconino Sandstone that contains evaporites. Gypsum, along with dolostone, sandstone, redbeds, chert, and minor limestone, comprise the sequence (Hopkins, 1990). The member thickens to the west (up to $85 \mathrm{~m}$ ) with significant bedded gypsum present. In fact, gypsum is mined from the Harrisburg member west of Las Vegas, Nevada at the Blue Diamond Hill Mine (Hopkins, 1990). A number of undeveloped occurrences and at least one gypsum mine have been identified 
in either the Coconino Sandstone and (or) Toroweap Formation in northwest Arizona (Keith, 1969a). To the best of my knowledge, no significant amounts of gypsum have been identified in the Harrisburg Member in the PNF.

However, the Coconino Sandstone and Toroweap Formations are permissive for bedded gypsum.

Lacustrine gypsum is found in the Verde Formation of Pliocene and Miocene ages (Weir and others, 1989) particularly in an area of $190 \mathrm{~km}^{2}$ of evaporites extending about $16 \mathrm{~km}$ northwest, and $10 \mathrm{~km}$ southeast of Camp Verde (fig. 1) in the Verde basin (Twenter and Metzger, 1963, fig. 24). Gypsum in the Verde Formation has been mined in a sequence of evaporites several square kilometers in area interbedded with mudstone and volcanic ash that can be $100 \mathrm{ft}(30 \mathrm{~m})$ thick). Lane (1992) notes that the material mined is about 70-75 percent gypsum. This suggest that the deposit is low grade within the context of the grade and tonnage model of lacustrine gypsum (Orris, 1992c). Also located in these evaporites is the Wingfiled-Mcledd gypsum deposit (Bliss, 1997, Appendix A and B) where gypsum was produced for use in agriculture. Another gypsum occurrence was noted near the Camp Verde Gypsum property (Bliss, 1997, Appendix A and B) and as part of the stratigraphic sequence at the Verde River Deposit (Bliss, 1997, Appendix A and B). Phillips and others (1998) also describes some sites which are or have been recently active. They include a site $8 \mathrm{~km}(5 \mathrm{mi})$ east of Camp Verde (fig. 1) which supplies gypsum for the cement plant at Clarkdale as well as for use in agriculture. Several other sites in the Verde Formation are noted for gypsum. For assessment purposes, these sites are discovered gypsum deposit(s). Perhaps the whole sequence exposed at the surface may be considered a deposit partially worked within the context of deposits described in the grade and tonnage model (Orris, 1992c). The Verde Formation is considered to be the permissive area for lacustrine gypsum.

\section{Resource estimate status}

No estimate of undiscovered deposits of either type was made. Marine gypsum deposits like those in the grade and tonnage model are large but it is unknown how extensive (or exhaustive) exploration has been for bedded gypsum deposits in the PNF. Existing data suggests that the situation for lacustrine gypsum is more promising than for the marine type. Grade may be a problem if the worked portion at Larson Quarry represents the best quality of material available. However, the presence of undiscovered deposits without outcrop for both types cannot be discounted. 


\section{Lacustrine halite, sodium sulfate, and brines}

\section{Background}

Halite $(\mathrm{NaCl})$, or salt, is used by the chemical and food industries and in snow and ice removal (Orris, 1992d). Lacustrine halite becomes important only locally when marine deposits are unavailable, as in Australia (Orris, 1992d). Halite is extracted by conventional mining to depths of $100 \mathrm{~m}$; and by solution mining at depths greater than $500 \mathrm{~m}$ (Orris, 1992d). Proximity to infrastructure and markets may be critical in deciding if a deposit will be worked, because transportation is a major contributive cost. Halite need not be directly mined but may also be extracted from natural brines and sea water.

Most sodium sulfate produced is used in the manufacture of detergents, paper, and glass (Harben and Bates, 1990). Two minerals, thenardite $\left(\mathrm{Na}_{2} \mathrm{SO}_{4}\right)$ and mirabilite $\left(\left(\mathrm{Na}_{2} \mathrm{SO}_{4} \bullet \mathrm{H}_{2} 0\right)\right.$, commonly called Glauber's salt, are commercially important. Sodium sulfate is also extracted from brines.

\section{Geology}

Lacustrine halite occurs as either bedded or massive bodies in continental basins (Orris, 1992d). Most deposits are late Tertiary or Quaternary. Basins are closed or semi-closed and contain sediments and evaporites developed under arid conditions. Due to high solubility, halite deposits are subject to considerable post-depositional modification, recrystallization, and remobilization. Sodium sulfate is common in alkali lakes and is found with other evaporites including halite and gypsum.

\section{Models}

Only the preliminary descriptive model by Orris (1992d) without an associated grade and tonnage model is available for lacustrine halite; however a constituents model is available for sodium carbonate (sulfate, chloride) brines (Orris, 1992a). These are brines considered sufficiently concentrated to be a source of their contained constituents (G.J. Orris, 1995, oral commun.) Ninety percent of the brines have a sum of $\mathrm{Na}_{2} \mathrm{CO}_{3}, \mathrm{Na}_{2} \mathrm{SO}_{4}$, and $\mathrm{NaCl}$ constituents equal to or greater than $6,400 \mathrm{ppm} ; 50$ percent have a sum equal to or greater than $33,000 \mathrm{ppm}$; and 10 percent of the brines have a sum equal to or greater than 220,000 ppm (Orris, 1992a, fig. 42-44). Neither a descriptive model or grade and tonnage model is available for sodium sulfate minerals.

\section{Deposits and tracts}

Lacustrine halite is found in the Verde Formation of the Pliocene and Miocene ages (Weir and others, 1989) particularly in an area of $190 \mathrm{~km}^{2}$ of 
evaporites extending about $16 \mathrm{~km}$ northwest, and $10 \mathrm{~km}$ southeast of Camp Verde (Bliss, 1997, fig. 1) in the Verde Basin (Twenter and Metzger, 1963, fig. 24). Halite in the Verde Formation has been mined, along with sodium sulfate. The Verde Formation is a sequence of evaporites several square kilometers in area interbedded with mudstone and volcanic ash that can be as much as $100 \mathrm{ft}(30 \mathrm{~m})$ thick.

Not only are halite deposits recognized, but brines are also present. A saline water well near Camp Verde contains 177,000 ppm dissolved solids, predominantly sulfate and chloride. This well appears to be consistent with the concentrations noted in the brine model by Orris (1992a). This would still be true if only a half of the soluble solutes present are the same as those in the model. A sample collected in 1959 from a ground-water well about $6 \mathrm{~km} \mathrm{(4}$ mi) southeast of Camp Verde along West Clear Creek was reported to contain 90,300 ppm dissolved solids largely dominated by sodium (+ potassium) and sulfate (Twenter and Metzger, 1963, table 10). This well may also be a source of usable brines. Detailed chemical analyses are needed for both wells as is an estimate of the size of the brine reservoir. In addition, possible discharge rates are needed.

Lane (1992) notes that a sodium sulfate deposit was mined west of Camp Verde. Weisman and Mcllveen (1983) describe the deposit as $46 \mathrm{~m}$ thick. It is unusual in that it contained pure mirabilite crystals.

For assessment purposes, these sites at the surface are for discovered halite/sodium sulfate deposit(s). The Verde Formation is considered to be the permissive area for lacustrine halite/sodium sulfate deposits and sodium carbonate (sulfate, chlorite) brines.

\section{Diatomite}

One occurrence of diatomite is reported south of Camp Verde. Lane (1992) cites oral communication (Ed Davidson, Superior Materials) that diatomite is present at the gypsum deposit $6 \mathrm{~km}$ southeast of Camp Verde. Samples examined from various sites in the Verde Formation appear to be of poor quality (Lane, 1992). Diatomite was also recognized in Milk Creek area, southeast of Walnut Grove (Eric Force, verbal commun., 1997). A descriptive model for lacustrine diatomite by Shenk (1991) is available; a grade and tonnage model is not. The Verde Formation is permissive for diatomite but the prognosis for occurrences of viable diatomite deposits based on available evidence is not promising. 


\section{Part III: Collectable Minerals}

\section{Introduction}

To my knowledge no quantitative assessment has ever been made of public lands for mineral resources that might be of interest to mineral collectors. A number of questions need to be addressed. Who collects minerals and why? What are the factors effecting mineral value? How are minerals marketed? What types of minerals do collectors like? What are the prices collectors pay for minerals? What minerals are present in the PNF? Are there types of mineral deposits or rocks that are particularly good sources of minerals sought by collectors? What is the probable value of these minerals, both known and undiscovered, in the PNF?

If all these questions can be successful answered, a quantitative assessment might be appropriate. Some answers will be attempted in the hope that they will be useful to those who undertake assessments of this type in the future.

\section{Who collects minerals and why?}

Minerals are collected by the general public as a hobby. In fact, the types and prices of minerals people collector are as diverse as collector's interests and budgets. Curators of museums are a special type of mineral collector who seek notable examples of minerals. A few individuals may also collect museum-quality material. Many people collect minerals for their beauty and rarity. Some minerals are collected because they are unusual or have attached romantic traditions. Gold is an example of this type of mineral. Some collectors seek to make a comprehensive collection of minerals from a mining district or region. Others focus on a few minerals but seek examples from many places.

Minerals are also collected for use. Some people collect minerals suitable for making jewelry or art. Hardness, workability, and aesthetics are important factors to these collectors. Others seek certain minerals, and crystals in particular, for religious purposes. Geoscientists collect minerals as part of their research. Some types of research require minerals of particularly high-purity. Educators collect minerals for use in teaching geology. Samples are needed for reference collections. Students need samples to inspect and mineral chips for testing purposes. 


\section{What are the factors effecting mineral value?}

The same factors that motivate collectors also effect mineral prices. However, a mineral specimen can undergo substantial change in price as it moves through the market place. John Betts ${ }^{3}$ recounts a whimsical tale of the price evolution of a mineral specimen from discovery to its ultimate return to the earth in a landfill. Along the way the mineral specimen trades hands many times selling for $50 \phi$ the first time. Later an offer of $\$ 1000$ is made for it. Each transaction is influenced by small and large events that effect the specimen's price.

A mineral specimen from a mine no longer accessible can demand a higher price then a similar mineral found in an operating mine. This is somewhat comparable to the price of an art piece by a successful living artist contrasted to the price after the artist has died. A mineral specimen may also sell for a higher price if it has been the subject of a scientific investigation resulting in a publication.

Effective marketing of minerals can increase prices as well. Collectors of mineral specimens can be encouraged to purchase minerals in the same way people with disposable incomes are encouraged to buy other discretionary commodities.

\section{How are minerals marketed?}

Minerals are marketed in three general categories. Gold-bearing specimens can also be considered a fourth category. That became apparent during this analysis.

Bulk minerals. These are sold by weight. No one sample of the mineral has greater or less value than the next when sold this way. Some materials for use in lapidary are sold in bulk.

Mineral specimens. These are marketed individually. Each specimen has a separate value based on all the factors discussed above. Mineral specimens usually are identified using length measurements. Some vendors also give the weight of mineral specimens and museum specimens. The following fairly exact classification is suggested by one vender:

1) micro--specimen with crystals that require magnification to truly enjoy,

2) miniature--has crystals no larger than $1 \mathrm{~mm}$ in size,

3) thumbnail--1 to $2.5 \mathrm{~cm}$ specimens with crystal greater than $1 \mathrm{~mm}$ to $2.5 \mathrm{~cm}$,

4) miniature--2.6 to $5 \mathrm{~cm}$ specimens with crystals larger than $1 \mathrm{~mm}$,

5) hand specimens-- 5.1 to $10 \mathrm{~cm}$ specimens; also called cabinet specimens, and

6) very large specimens--larger than $10 \mathrm{~cm}$, with crystals larger than $1 \mathrm{~mm}$.

Museum specimens These, like mineral specimens, are marketed individually, and the prices are based on the same factors that effect mineral

\footnotetext{
${ }^{3}$ http: //www.rockhounds.com /rockshop/john-betts/sohigh_html
} 
specimen prices. Additionally, museum specimens usually are very large, lack damage, and have exceptional aesthetic value and (or) rarity.

\section{What are the types of minerals of interest to collectors?}

Panczner and Panczner (1988) offer a list of minerals or mineral groups that one may expect to be of interest to the more casual mineral collector. Those found in or adjacent to PNF based on Anthony and others (1995) are given in Table 2.

Table 2. Minerals of possible interest to casual mineral collectors and found in or adjacent to the PNF.

\begin{tabular}{|l|l|l|}
\hline aragonite & copper & magnetite \\
\hline arsenopyrite & cuprite & malachite \\
\hline azurite & dioptase & olivine (peridot) \\
\hline barite & dolomite & pyrite \\
\hline beryl & epidote & $\begin{array}{l}\text { quartz (amethyst, agate, rock } \\
\text { crystal) }\end{array}$ \\
\hline biotite & $\begin{array}{l}\text { feldspars (microcline, orthoclase, } \\
\text { plagiolcase) }\end{array}$ & scheelite \\
\hline bornite & fluorite & siderite \\
\hline calcite & galena & silver \\
\hline cerussite & $\begin{array}{l}\text { garnets (pyrope, uvarolite, almandine, } \\
\text { spessartine, grossular, andradite) }\end{array}$ & sphalerite \\
\hline chalcocoite & gold & tourmaline \\
\hline chalcopyrite & gypsum (selenite) & vanadinite \\
\hline chrysocolla & halite & wulfenite \\
\hline cinnabar & hematite & \\
\hline
\end{tabular}

This is only one possible list of many. As noted above, these minerals may be of more interest to casual mineral collectors who have a passing interest in minerals. They are also more likely to be interested in the lower price mineral specimens sold in rock shops, at street fairs, and at airports. Commonly, these specimens are sold from bins where no one sample of the mineral has a greater or lesser value than the next. This is an example of a bulk mineral.

Serious collectors of minerals are more likely to be interested in mineral specimens sold individually or ones they find and extract themselves. The types of minerals in which they may be interested also number in the hundreds. In addition, minerals have many forms and specimens can have many types of mineral combinations that increase the possible types of specimens collectors may acquire. Examples of mineral specimens are given in the following sections. 
Most collectors usually have some size limitations on the specimens they want so that they can be readily transported and shown. They also need to be securely stored. Museums have similar limitations, albeit they do have the ability to collect both large-sized as well as more expensive specimens. They also have some larger security issues as well. Some high-end collectors do join museum curators in the purchase of museum-quality mineral specimens.

A survey of 104 mineral specimens (including a few museum specimens) for sale were found to have weights between $10 \mathrm{~g}$ and $50 \mathrm{~kg}$ (excluding gold samples). However, the vast majority of specimens were between $90 \mathrm{~g}$ and $3 \mathrm{~kg}$. The median specimen weight is $590 \mathrm{~g}$. This puts most specimens in the hand specimen size group and few in the very larger size group.

\section{What are the prices collectors pay for minerals?}

\section{Introduction}

Minerals are retailed to the public in three broad categories that are identified above in the discussion on minerals marketing. The categories are bulk minerals, mineral specimens and museum specimens. Lapidary material can be found in all three of these categories but as they appear to have a limited presence in the PNF area are not included in this study. Questions concerning prices include: what is the nature of the price structure within each category? Is there overlap in price among categories?

Data for use in price analysis includes the retail prices of 127 mineral and museum specimens, and 220 types of minerals sold by bulk. Database entries are from a survey of public sources given at retail sites on the world wide web and elsewhere. A few sample weights in the database were estimated using mineralogical and geometric data provided at the web site. Data are expressed as dollars per gram $(\$ / g)$ or cents per gram $(\varangle / \mathrm{g})$ for all categories. Museum specimens were included with the mineral specimen category as only a few large-sized specimens were found during data compilation. Initial data inspection also revealed that gold-bearing specimens were far more expensive than other types of mineral specimens and therefore are treated as a fourth category.

Comparison was made between three categories--bulk minerals, mineral specimens and gold-bearing specimens. Comparison was made using boxplots (fig. 15) which show the differences of price distributions within and among categories. See section entitled "Graphics and statistics" for a discussion on boxplot layout.

Categories in declining order of median price are gold-bearing specimens, mineral specimens, and bulk minerals (fig. 15). Gold-bearing specimens have prices that do not overlap with other categories. Substantial, 
and perhaps somewhat unexpected, overlap is present between mineral specimens and bulk minerals. This is discussed below.

\section{Gold-bearing specimens}

The most expensive category is the one for gold-bearing specimens. They have prices between $\$ 21$ and $\$ 53 / \mathrm{g}$. The prices of gold-bearing specimens is less variable than other categories as shown by the narrower boxplot (fig. 17). The median price of the 23 specimens is $\$ 31.63 / \mathrm{g}$; 50 percent of the values defined by the left and right edge of the box are between $\$ 26.66$ and $\$ 36.90 / \mathrm{g}$. Eighty percent of the prices are between $\$ 21.17$ and $44.09 / \mathrm{g}$-- the range of prices between the left and right fences (fig. 17)

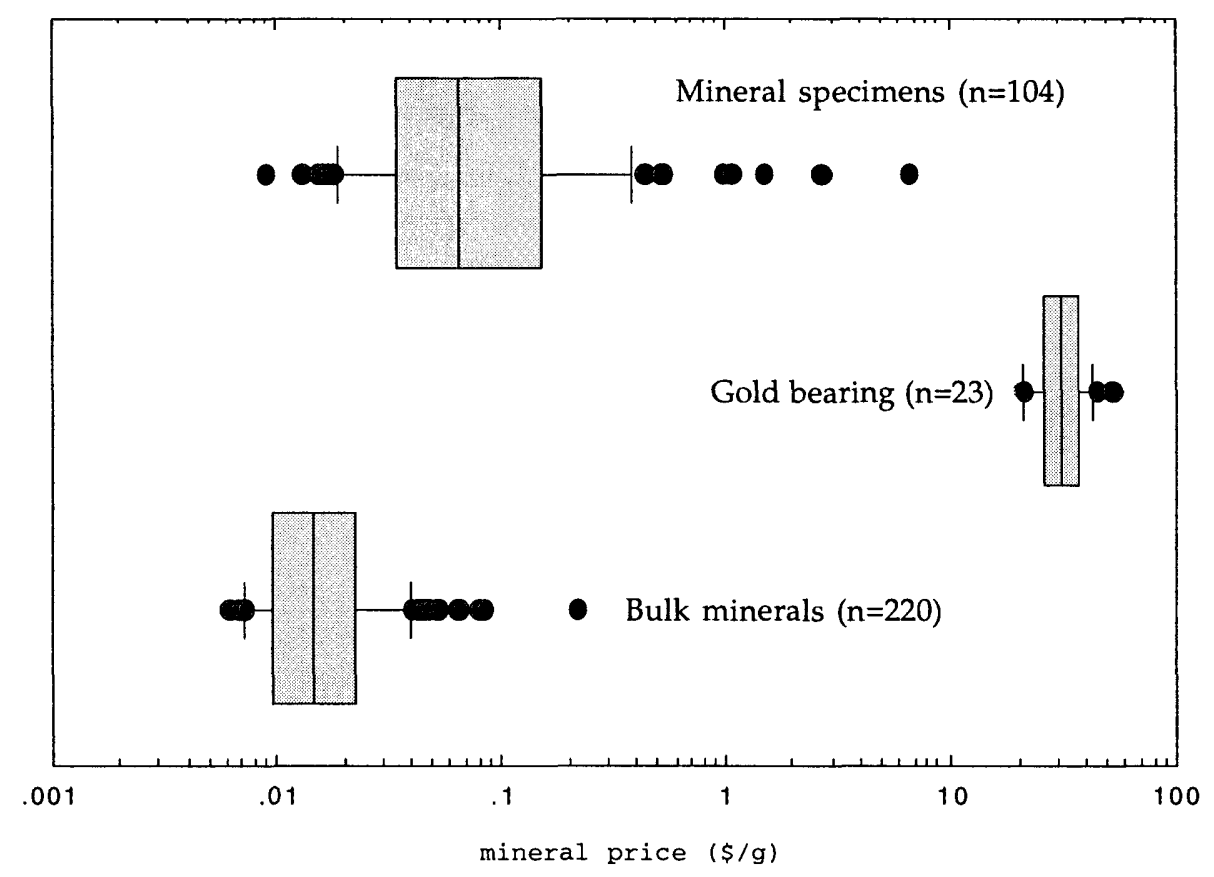

Figure 17. Boxplots of mineral prices $(\$ / g)$ sold by bulk (unit weight) and sold as individual specimens. Data found on the world wide web and elsewhere. Note that mineral prices are scaled in logarithm base 10. Gold bearing specimens are treated separately here. See text for explanation of boxplot layout.

Gold-bearing specimens differ from other mineral specimens in a number of ways. Some include man-made products like amalgamate and bullion. Specimens are also sold as single lots--each made up of a number of smaller natural grains, crystals and pieces. Gold-bearing specimens include gold crystals that demand the highest prices--usually between $\$ 40$ to $\$ 50 / \mathrm{g}$. One sample of crystals in the data is from Bumblebee, Ariz. and was collected in 1933. Other specimens in the data are a number of gold nuggets including 
ones collected in Arizona at Turkey Creek, near Congress Junction in 1993, and Troy in 1953. Placer gold pieces found at Mayer, Ariz. in 1912 are listed at $\$ 26.47 / \mathrm{g}$.

Gold-bearing specimens have retail prices sensitive to the value of gold as a commodity. One commonly used rule-of-thumb to measure this relationship is by multiplying the specimen weight by gold price by one and half; another rule-of-thumb is to multiple weight by gold price by two. A comparison to the median prices of the 23 gold-bearing specimens in the data set to $\$ 300$ per troy ounce gold $(\$ 9.60 / \mathrm{g}$ ) suggest the specimen weight should be multiplied by 3.3. The chances are four out of five the multiplier is between 2.2 and 4.6. This may be more realistic for a rule-of-thumb. For gold crystals, multiple the value by 4.4 .

\section{Bulk Mineral types}

As expected, the cheapest category is the one for bulk minerals (Table 3 ). They have prices between $0.6 \notin / g$ and $22 \phi / g$ (fig. 17). The prices of bulk minerals are less variable than mineral specimens but more so than for gold-bearing specimens. The median price of 220 types of bulk mineral specimens is 1.5 $\phi / g$; 50 percent of the values defined by the left and right edge of the box are between $0.9 \notin$ and $2.2 \varangle / \mathrm{g}$. Eighty percent of the prices are between $0.7 \notin$ and 4 $\phi / g$--the range of prices between the left and right fences (fig. 17). If bulk minerals could be produced by the $t$, the median retail value would be $\$ 15,000 / \mathrm{t}$. Prices of bulk mineral types can be higher as seen by the scattering of points to the right of the boxplot.

Table 3. Types and some common characteristics (in parentheses) of minerals sold in bulk. Those also listed in the Table 5 that give minerals identified in or adjacent to the PNF are designated by with a "*" in this table. Note: some common minerals may be present in or adjacent to the PNF but may not always be listed in Table 5,

\begin{tabular}{|l|l|}
\hline Actinolite & Halite* (cleavable, coarse grains, rock salt) \\
\hline Albite* (see plagioclase, Table 5) & $\begin{array}{l}\text { Hematite (black, massive, oolitic, red, red } \\
\text { ochre, specular, cleavable) }\end{array}$ \\
\hline $\begin{array}{l}\text { Amazonite (no green microcline noted in } \\
\text { Table 5) }\end{array}$ & Hornblende (crystalline, massive) \\
\hline Amblygonite & lmenite \\
\hline Amethyst & Jade \\
\hline Andesine* (see plagioclase, Table 5) & Kaolin (less than 200 mesh, massive) \\
\hline Andradite & Kyanite \\
\hline Anhydrite (see section on gypsum) & Labradorite (cleavable, crystalline) \\
\hline Anorthite* (see plagioclase, Table 5) & Lepidolite \\
\hline Anorthoclase & Limonite \\
\hline Apatite (massive and crystalline)* & Magnesite* (black, crystalline, lodestone) \\
\hline
\end{tabular}




\begin{tabular}{|c|c|}
\hline Aragonite* & Malachite* \\
\hline Arsenopyrite* & Manganite \\
\hline Augite (massive and cleavable) & Microcline* (pink, white) \\
\hline Azurite & Molybdenite (minus 200 mesh) \\
\hline Azurite (dark blue) & Muscovite (cleavable, matted) \\
\hline Azurite (with chrysocolla and cuprite) & Nepheline \\
\hline Barite* & Nickeline \\
\hline Bauxite & Oligoclase* \\
\hline Beryl* & Olivine* (coarse, fine) \\
\hline Biotite & Opal (also see quartz) \\
\hline Bornite* & Orpiment \\
\hline Bornite (with covellite and pyrite) & Perthite \\
\hline Bytownite & Phlogopite \\
\hline $\begin{array}{l}\text { Calcite* (cleavable, chalk, fluorescent, } \\
\text { crystalline, spar, iceland spar, mexican } \\
\text { onyx, Bisbee ice) }\end{array}$ & Plagioclase* \\
\hline Cassiterite & Pryite (fools gold, massive, pure, rocky) \\
\hline Cerussite & Pyrolusite \\
\hline Chalcocite* & $\overline{\text { Pyrrhotite }}$ \\
\hline Chalcopyrite* (massive) & $\begin{array}{l}\text { Quartz* (multicrystalline, crystal chunks, } \\
\text { crystal, crystal rock, clusters, rutilated, } \\
\text { small single crystals, agate, amethyst, rose, } \\
\text { chalcedony, chert, chrysoprase, silicified } \\
\text { wood, smoky, tiger eye) }\end{array}$ \\
\hline Chlorite & Realgar* \\
\hline Chromite & Rhodochrosite \\
\hline Chrysocolla* & Scapolite* \\
\hline Cinnabar* & Scheelite* \\
\hline Copper (nugget) & Serpentine \\
\hline Corundum (crystalline, in matrix) & Siderite* \\
\hline Cryolite & Sodalite \\
\hline Cuprite & Sphalerite* (crystalline, cleavable) \\
\hline Diopside* & Spodumene \\
\hline Dolomite* (cleavable, coarse, crystalline) & Staurolite* \\
\hline Enstatite & Stibnite* \\
\hline Epidote* & Sulfur* (massive, crystalline) \\
\hline Fluorite* (cleavable, fluorescent, massive) & Sylvite \\
\hline Galena* (cleavable) & Talc (foliated, soapstone) \\
\hline Garnet (almadine with hornblende) & Topaz (massive, crystalline) \\
\hline Glaucophane & Tourmaline \\
\hline Goethite & Vermiculite \\
\hline Graphite (foliated, pure) & Willemite \\
\hline Grossular & Wollastonite \\
\hline $\begin{array}{l}\text { Gypsum* (alabaster, massive, satin spar, } \\
\text { selenite) }\end{array}$ & Zircon* \\
\hline
\end{tabular}

Bulk minerals can have higher prices when the supply is limited. For example, a large amount of material with an uncommon mineral assemblage, and available only from one mine, may be retailed like other 
bulk minerals but at a relatively higher price. This is one, and certainly not the only, reason overlap is present between specimen minerals and bulk minerals (fig. 15). In fact about 90 percent of bulk mineral types have prices comparable to the lowest 40 percent of the prices for mineral specimens. This is also partly due to the fact that some bulk mineral types have higher prices related to mineralogy--this is somewhat like the problem commonly referred to as comparing apples and oranges. A clearer comparison might be possible if it was done using specimens and bulk mineral prices for the same mineral. Such a comparison is made and discussed below.

\section{Mineral specimen types}

As expected, the mineral specimen category is more expensive as a group than minerals sold in bulk. It also has the largest variability of the three categories considered. Prices are between $0.9 \notin / \mathrm{g}$ and $\$ 6.67 / \mathrm{g}$ (fig. 17). The median price of 104 mineral specimens is $6.4 \mathrm{\&} / \mathrm{g}$; 50 percent of the values defining the left and right edge of the box are between $3.5 \phi$ and $15 \phi / g$. Eighty percent of the prices are between $1.9 \notin$ and $38 \notin / g$--the range of prices between the left and right fences (fig. 17). If mineral specimens could be produced by the $t$, the median retail value would by $\$ 64,000 / t$. As noted above, considerable overlap is also present with bulk minerals prices. Table 4 gives a list of a few examples provided by retailers of mineral specimen descriptions including some source locations:

Table 4. Examples of minerals and descriptions of mineral specimens.

\begin{tabular}{|l|l|}
\hline Adamite & $\begin{array}{l}\text { Garnet (in schist, California; Mexico; } \\
\text { Puget Sound, Washington, with mica; } \\
\text { with chalcopyrite) }\end{array}$ \\
\hline $\begin{array}{l}\text { Amethyst (cluster; 5 cm crystal with } \\
\text { some chips) }\end{array}$ & $\begin{array}{l}\text { Gypsum (Chihuahua, Mexico; } \\
\text { Oklahoma }\end{array}$ \\
\hline Aragonite (Cochise Co., Ariz.) & $\begin{array}{l}\text { Garnet (in schist, California; Mexico; } \\
\text { Puget Sound, Washington, with mica; } \\
\text { with chalcopyrite) }\end{array}$ \\
\hline Aragonite (Sicily, Morroco) & $\begin{array}{l}\text { Gypsum (Chihuahua, Mexico; } \\
\text { Oklahoma }\end{array}$ \\
\hline $\begin{array}{l}\text { Azurite (with copper carbonates, } \\
\text { malacite; with malacite) }\end{array}$ & Malachite (banded, with galena) \\
\hline $\begin{array}{l}\text { Azurite and malacite (Morenci, } \\
\text { Ariz.) }\end{array}$ & Mica (Brazil) \\
\hline Barite (Barton Co., Georgia) & $\begin{array}{l}\text { Pyrite (after anhydrite, Pakistan; cubic } \\
\text { in matrix; in quartz crystal; Zacatecas, } \\
\text { Mexico) }\end{array}$ \\
\hline $\begin{array}{l}\text { Beryl (Ruggles Mine, New } \\
\text { Hampshire) }\end{array}$ & $\begin{array}{l}\text { Quartz (crystal cluster, single crystal, } \\
\text { dogtooth, with copper carbonates, } \\
\text { Arizona) }\end{array}$ \\
\hline
\end{tabular}




\begin{tabular}{|l|l|}
\hline $\begin{array}{l}\text { Calcite (Chihuahua, Mexico; Korea, } \\
\text { Peru) }\end{array}$ & $\begin{array}{l}\text { Rhodochrosite (with fluorite and } \\
\text { quartz) }\end{array}$ \\
\hline Cerussite (Redburn Mine, England) & Rutile (Brazil) \\
\hline Chalcopyrite (with dolomite). & Schorl \\
\hline Chrysocolla & Selenite (Manitoba) \\
\hline $\begin{array}{l}\text { Epidot, (Madagascar; Prince of } \\
\text { Wales Island, Alaska) }\end{array}$ & $\begin{array}{l}\text { Sphalerite (with calcopyrite, calcite } \\
\text { crystals, dolomite; large crystal with } \\
\text { quartz and pyrite; large calcite crystal } \\
\text { with small sphalerite crystals) }\end{array}$ \\
\hline $\begin{array}{l}\text { Fluorite, (green; China; Hardin Co., } \\
\text { Illinois; Hunan Provence, China; } \\
\text { museum quality, with galena and } \\
\text { quartz; purple with quartz, cubic } \\
\text { galena; small transparent cubes) }\end{array}$ & Wulfenite, (Durango, Mexico; Arizona) \\
\hline $\begin{array}{l}\text { Galena (Missouri; with esseneite, } \\
\text { Burma) }\end{array}$ & \\
\hline
\end{tabular}

These specimens are retailed individually and in 1998 usually had a price between $\$ 10$ to 400 dollars each. The median price was $\$ 40$ based on 104 examples. The possible relation of mineral specimens, and museum specimens is graphically shown on figure 18. The horizontal axis is mineral specimen size $(\mathrm{g})$ and the vertical axis is specimen price in $\$ / \mathrm{g}$. Larger specimens appear to have values almost always greater than $1 \varangle / \mathrm{g}$. Smaller specimens (less than $100 \mathrm{~g}$ ) have prices between $10 \phi / \mathrm{g}$ and $\$ 1 / \mathrm{g}$. Two lines of equal value are $A$ for $\$ 10$ specimens and B for $\$ 400$ specimens. Nearly all 


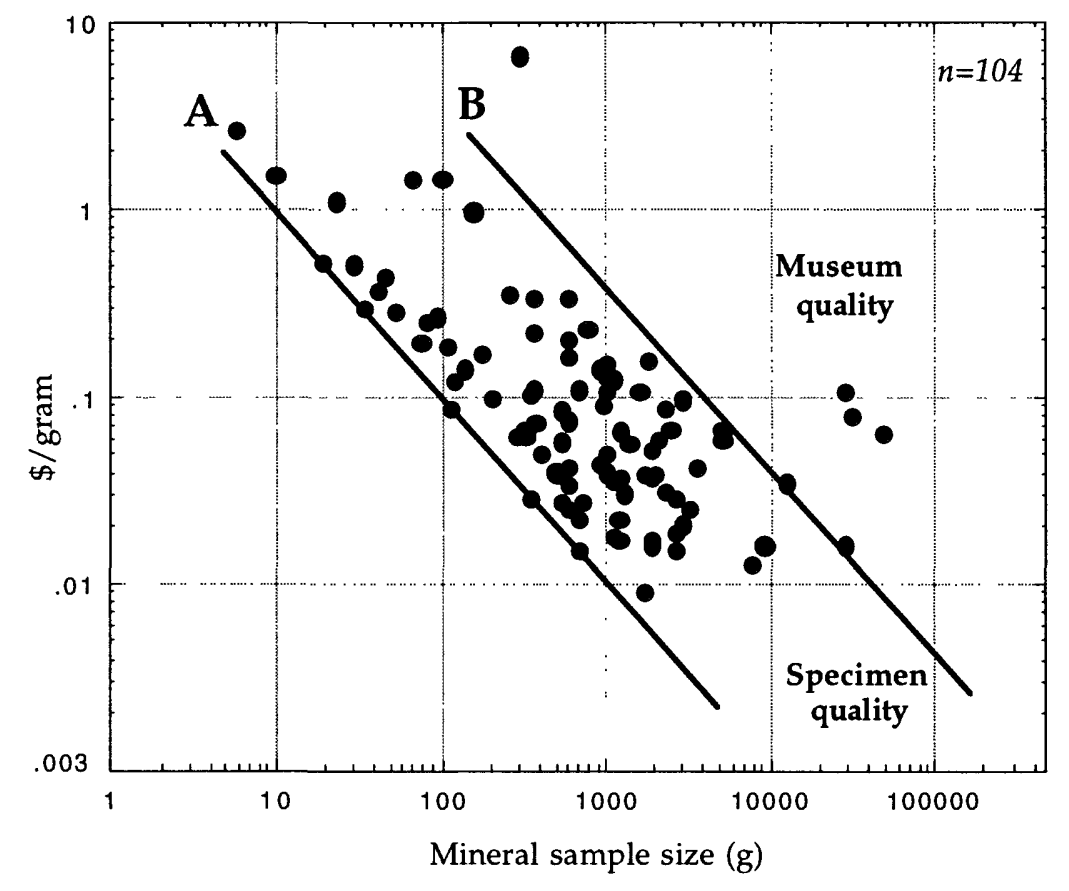

Figure 18. Bivariate scatter plot of mineral value $(\$ / g)$ and mineral sample size $(\mathrm{g})$. Note both axes are logarithymic base 10 . Specimens along line A are $\$ 10$ samples and those along line B are $\$ 400$ samples. Note that mineral sizes are scaled in logarithm base 10.

samples are bound by these two lines. Points to the left of B are more likely to be for museum quality specimens that also may be of interest to some highend collectors.

\section{Mineral specimens classified by mineralogy}

Do some specimen mineral types demand a higher price per unit weight? One problem is that specimens commonly can contain several minerals as demonstrated in the list above. Even though data on 104 specimens were available, a large number of specimen types were also present. To insure groups be larger for comparison purposes, some consolidation was necessary. For example, all of the various types of copper minerals were grouped together. A single group was also made of the numerous types of lead minerals. Typical gypsum minerals were grouped with selenite. Quartz specimens were grouped with amethyst specimens. Aragonite and dolomite were grouped with calcite. Beryl and tourmaline were grouped together as cyclosilicate minerals. Excluding the cyclosilicates, groups represented by three or fewer examples in the data set were excluded from analysis.

Comparison between the 12 groups is done using boxplots (figure 19). The number of specimens used for each group is also given. Mineral 


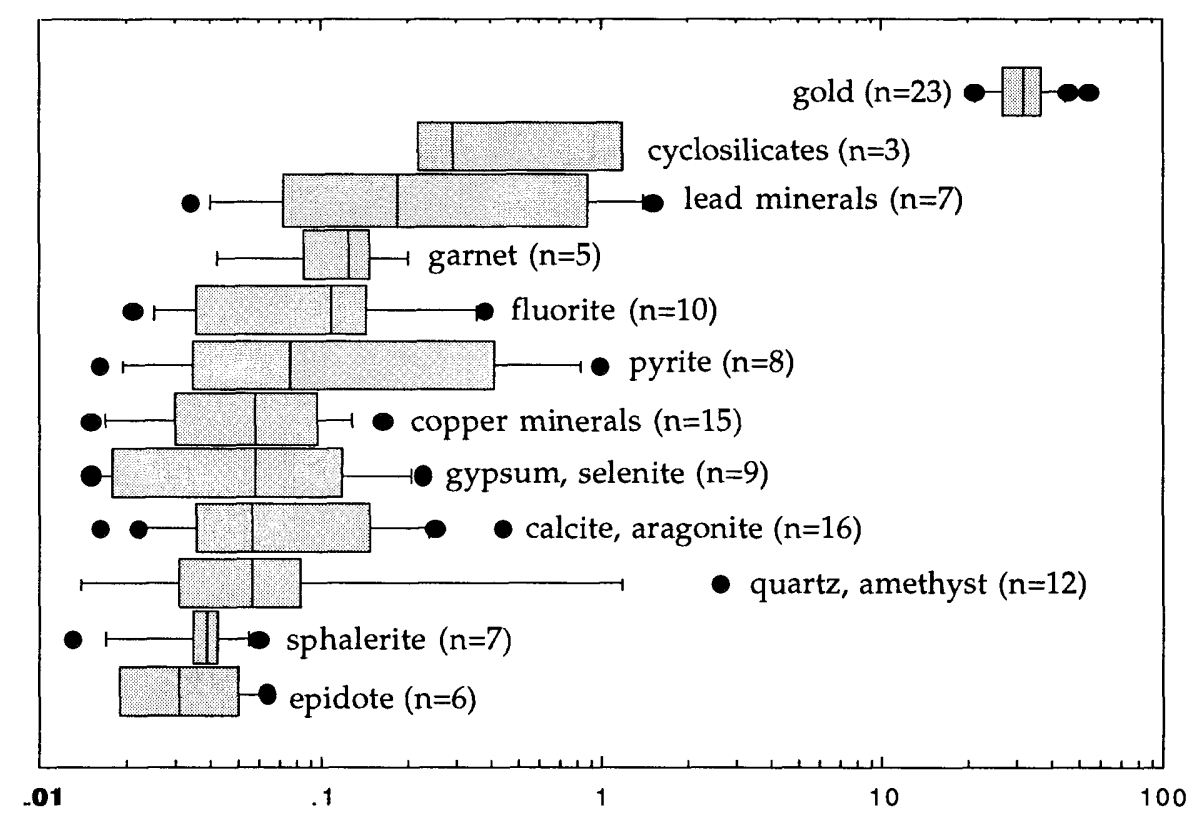

Figure 19. Boxplots of prices $(\$ / g)$ grouped by types of mineral specimens. Data found on the world wide web and elsewhere. Note that mineral prices are scaled in logarithm base 10. See text for explanation of boxplot layout.

specimen types with lower prices are at the bottom; those with higher prices are at the top. The number of specimens per group are still small and may not be representative of mineral prices. This needs to be kept in mind in the following discussion.

The lowest price mineral specimen types (fig. 19) are epidote (median of $3.1 \notin / g)$ and sphalerite $(3.8 \notin / g)$. The data set for epidote and sphalerite are both small. The next four groups of mineral specimens have slightly higher median prices and ones essentially identical to each other. They include quartz $(5.6 \notin / g)$, calcite $(5.6 \notin / g)$, gypsum $(5.7 \notin / g)$ and copper minerals $(5.8$ $\Varangle / g)$. Quartz, calcite, and copper minerals are represented by more observations than typical. One outlier $(\$ 2.63 / \mathrm{g})$ in the quartz boxplot may be for a specimen of amethyst of possible gem quality. Calcite specimen prices tend to be skewed to higher values (box is asymmetrical to the right) as compared to gypsum specimen prices that tend to be skewed to lower values (box is asymmetrical to the left) as depicted in figure 17. The value of median copper minerals is 1.8 times the value of the lowest median price $(3.1 \notin / \mathrm{g})$ for epidote.

The next mineral groups, in ascending order of medians (fig. 19), are pyrite $(7.7 \notin / g)$, fluorite $(11 ф / g)$, garnet $(12 ф / g)$ and lead minerals $(19 \phi / g)$. Small data set size is a problem with all these mineral groups. Relatively large changes in unit price are present for these mineral groups. Lead, garnet, and fluorite mineral specimens are likely to have been at two to three times 
the price of minerals when compared to copper minerals and those below (fig. 19). Substantial variability is also present shown by elongated boxplots with long whiskers (note mineral price axis is in logarithm base 10). For example, some pyrite specimens are likely to have higher prices than some lead specimens with values at or near their median value (fig. 19).

The number of cyclosilicates--represented by three beryl and tourmaline here--is small and the data may be biased by high priced specimens. Some may be gem quality. Gold-bearing specimens clearly have much higher prices and have been discussed previously (see section entitled Gold-bearing specimens.)

\section{Bulk minerals and collectors specimens by mineralogy}

As noted earlier, considerable overlap in price per unit weight occurs between bulk minerals and specimen minerals. In order to better understand this, bulk mineral types and specimen types were reexamined and classified using mineralogy. Clearly more data is desirable for a more complete and reliable analysis. Each boxplot is identified by mineral type(s) and number of specimens it represents; boxplots are ordered from low to high medians for mineral specimens from bottom to top of figure 20 .

Epidote and garnet are not included in this analysis since too few prices for bulk sales were available. Sphalerite has three bulk retail prices (fig. 20) with a median of $1.6 \varnothing / \mathrm{g}$. Specimen epidote has a median value of 2.4 times this price at $3.8 \notin / g$. As mentioned above, the next four groups of mineral specimens--quartz, calcite, gypsum, and copper minerals have slightly higher median prices for mineral specimens and are essentially identical to each other (5.6 to $5.8 \varangle / \mathrm{g})$. However, their bulk mineral prices are quite different from each other. Quartz median bulk mineral price is $1.7 \varnothing / \mathrm{g}$; the specimen median value is 3.2 times this price at $5.6 \mathrm{\&} / \mathrm{g}$, Calcite has a bulk mineral price of $1.5 \varangle / \mathrm{g}$ a little less than that for quartz bulk minerals. The specimen median value is 3.7 times this price at $5.6 \mathrm{c} / \mathrm{g}$. Gypsum shows the greatest change for these four minerals. The bulk mineral price is $0.9 \phi / g$, the lowest value in the data; the specimen median value is 6.3 time this price at $5.7 \mathrm{q} / \mathrm{g}$. This may be due to wider availability of bulk gypsum. Copper minerals also exhibit the least change in value from bulk to specimen. Boxplots also show considerable overlap. The bulk mineral price of copper minerals is $2.1 \notin / \mathrm{g}$; the specimen median value is 2.76 times this price at $5.8 \mathrm{~d} / \mathrm{g}$.

Pyrite is the mineral where increased specimen prices begin to be readily observed (fig. 20) . Pyrite has seven bulk retail prices listed with a median of $1.5 \varnothing / \mathrm{g}$; the specimen median value is 5.1 times this price at $7.7 \varnothing / \mathrm{g}$. Fluorite minerals have four bulk retail prices listed with a median of $1.6 \not / g$; this is the same price as for bulk sphalerite--the cheapest mineral specimen type in the data. The specimen median value of fluoirte minerals is 6.7 times this price at $11 \propto / \mathrm{g}$. Lead minerals are poorly represented by bulk pricing data--only three figures are available with a median of $1.9 \notin / g$--this is 


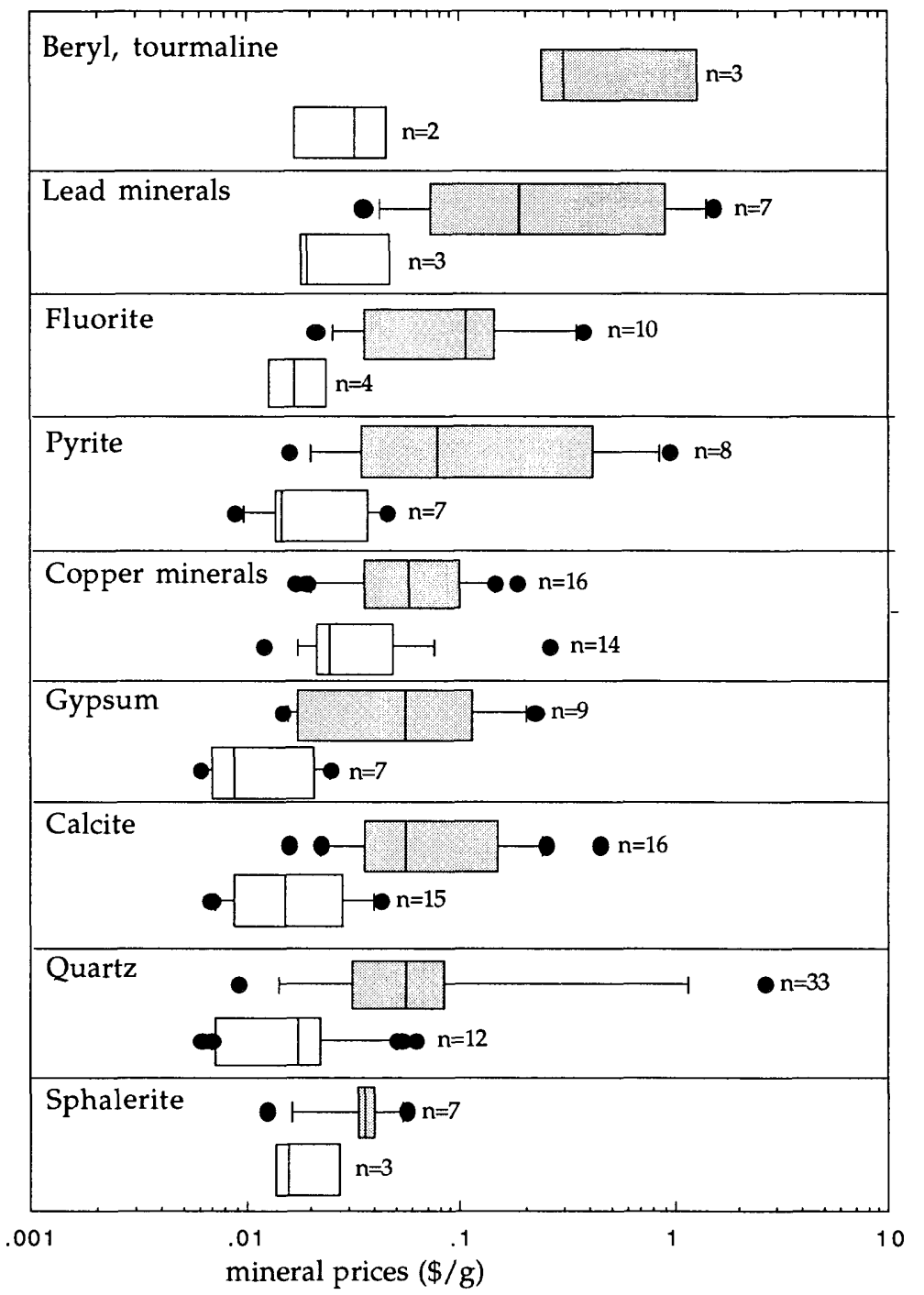

Minerals retailed in bulk $\square$ Minerals retailed as individual specimens

Figure 20. Boxplots of mineral type prices $(\$ / g)$ sold by bulk and sold as individual mineral specimens. Data found on the world wide web and elsewhere. Note that mineral prices are scaled in logarithm base 10. See text for explanation of boxplot layout.

less than that for bulk copper minerals of $2.1 \% / \mathrm{g}$. The specimen median value for lead minerals is 9.8 times the bulk median price at $18.7 \mathrm{\&} / \mathrm{g}$. The most expensive mineral considered in this analysis is the cyclosilicates--here represented by beryl and tourmaline. These material are used as gems and value may also be due partly to scarcity. The number of data in the analysis is also very small. Beryl and tourmaline are poorly represented by bulk pricing data--only two figures are available with a median of $2.9 \phi / g$; the specimen median value for beryl and tourmaline is 9.9 times the bulk median price at $28.8 \not / \mathrm{g}$ based on just three specimens. 
Market demand and mineral supply dictate the price of minerals sold in bulk or as individual specimens. This analysis suggests that many minerals (sphalerite, quartz, copper minerals, calcite, and gypsum for example) can have specimen prices on the order of 2 to 4 times that of the material retailed in bulk. Gypsum is notable for having very low bulk prices. Lead and fluorite minerals are notable for having high specimen prices that are on the order of 5 upward to 10 times that of the material retailed in bulk. Pyrite has an intermediate status with a somewhat high bulk price-comparable to fluorite--but with not-so-high specimen prices. Pyrite is also characterized by considerable price variability much like that shown for lead minerals.

It is likely that minerals retailed in bulk may also help to increase their demand for specimens of the same mineral type. Hobbyists who convert from casual to serious collectors may desire to have better examples of the mineral with which they are already familiar.

\section{What minerals are present in the PNF?}

\section{Introduction}

The minerals found in or adjacent to the PNF are listed in table 1 as identified in Anthony and others (1995). One can expect many of the sites to be inaccessible particularly if abandoned or in an operating mine. Abandoned mines either underground or surface can be extremely dangerous. Mine sites over or adjacent to underground or surface workings can be unstable. One can also expect minerals to be found in other sites not listed where the appropriate geology is present. Some minerals may be noted but may not be of interest to collectors; other minerals may be missed in this compilation. Be sure to check location information and legalities of access using sources cited in Anthony and others (1995) and other reports about the area.

As noted in Blair (1992), rock and mineral collecting for hobby purposes is generally permitted in lands administrated by the U.S. Forest Service and the Bureau of Land Management. Be aware that the Antiquities Act of 1906 specifically prohibits removal of artifacts including arrowheads, spearpoints, metates, manos and pottery shards from all public and federal lands.

\section{Rare new minerals of the United Verde Mine fire}

A number of unusual minerals developed as result of the spontaneous combustion of unstable sulfides at the United Verde Mine at Jerome (Anthony and others, 1995). The fire started in 1894 and burned for several decades. Attempts to exhaust the fire included injection of water, carbon dioxide, and steam under pressure. One or more of the injected materials remobilized small amounts of the metals in the deposit that were later redeposited in rocks above the fire as newly formed hydrated sulfate minerals (Anthony and others, 1995). Seven of the 11 newly deposited minerals were 
previously unknown and were found in fractures in fine-grain jasper and cracks in pyrite. New minerals initially included: butlerite, guildite, ransomite, and rogersite that later was renamed lausenite (Anthony and others, 1995). Jeromite was later identified as a coating inside of iron hoods used to protect miners from active gas jets. Other minerals found later from rocks above the fire include claudetite, yavapaiite, and the first reported natural occurrence of elemental selenium.

\section{Calcite}

A number of different types of calcite are of interest to collectors. Calcite formation encompasses a variety of depositional situations including sedimentary, springs, and hydrothermal systems. Onyx marble and Mexican onyx have colored banding and are of particular interest to collectors as a decorative stone (Anthony and others, 1995). They should not be confused with true onyx made of silica. Calcite formed by springs is called travertine.

The sites noted here and described in Anthony and others (1995) are representative as calcite is very widespread in and adjacent to the PNF. Beautiful specimens of crystallized calcite associated with quartz, adularia and metal ore minerals have been collected from the Cash mine, Hassayampa district of the Bradshaw Mountains.

Banded travertine used as a decorative stone comes from the Big Bug Creek adjacent to Mayer. Blair (1992) describes the material as occurring as boulder to cobble sized material at the surface with a weather brown (and uninteresting) outer coating. On cutting, the material reveals brown and yellow banding with cream-colored layers and occasionally a bit of red. Blair (1992) reports that the material tends to be of good quality although some is vuggy and colorless. The material is best used as bookends, carvings, or for spheres as it lacks hardness for lapidary use.

Manganiferous banded travertine is found near the town of Cordes Junction (fig. 1). Travertine is found adjacent to Castle National Monument. It is also found replacing glauberite crystals in lacustrine deposits of the Verde River Basin.

Optical-quality calcite crystals are found in numerous veins 3 miles southeast of Castle Hot Springs (Anthony and others, 1995) in the south end

of Bradshaw Mountains. This is on the order of 10 miles from the south edge of PNF but comparable occurrences may also be present within the forest as well.

\section{Jaspilite and tactonite}

Materials found in the PNF of potential use in lapidary are jaspilite and tactonite. Harrer (1964, p. 20) defines jaspilite as a "compact siliceous, very fine-grain rocks composed of interbedded layers of hematite-magnetite and red to black chert." Also noted in the PNF are numerous sites with tactonite. Harrer (1994, p. 20) defines it as "ferruginous chert or ferruginous slate in the 
form of a compact, siliceous rocks, in which the iron oxide is so finely disseminated that substantially all of the iron-bearing particles of merchantable grade are smaller than 20-mesh." On the face of it, jaspilite is likely to be more suitable for lapidary; however jaspilite and tactonite from the numerous sites described by Harrer (1964) would have to be individually sampled and tested. There is undoubtedly substantial variability in material quality. Best sites are likely those described as having excessive chert, vug free, and having low iron content. In other words, these sites considered as poor sources of iron may be better sources of lapidary material! Perhaps sites with high $\mathrm{SiO}_{2}$ content should be examined first (Harrer, 1964, Table 10).

A number of jaspilite sites are noted in rocks of the early Proterozoic Yavapai Supergroup of the Black Hills (Harrer, 1964, p. 94-99), dominantly in or adjacent to the Verde RD. Sites include Black Buck-Three Points magnetite jaspilite, Black Chief (Warrior) magnetite jaspilite, Black Gold magnetitehematite jaspilite, Cash Reserve Magnetite jaspilite, and Yaeger (Vojnich) hematite-magnetite jaspilite (Harrer, 1964). These are just a few of a large number of sites along a 9 mile trend in the Black Hills (Harrer, 1964, p. 94-99). The $\mathrm{SiO}_{2}$ content of 9 samples from 5 sites was between 25.2 to 53 percent (Harrer, 1964, Table 16). The median is estimated to be 33 percent. The highest value in these samples (53 percent) was the one from the Yaeger and Yaeger (Vojnich) hematite-magnetite jaspilite site (Harrer, 1964, Table 16).

Another source of lapidary material may be magnetite-hematite and magnetite taconites. They are common in the early Proterozoic Yavapai Supergroup of the Bradshaw RD. Two and perhaps as many as four intermittent sets of taconite beds are seen, usually running north to northeast, and for nearly the length of the RD south of Prescott (Harrer, 1964, fig. 19). The west belt runs from Lynx Creek south through sites at Goodwin, Blind Indian-Arrastra Creek-Longfellow Ridge, Pine Creek, to a point about 8 $\mathrm{km}(5 \mathrm{mi})$ southwest of Crown King. The $\mathrm{SiO}_{2}$ content (Harrer, 1964, Table 16) was highest at Lynx Creek (52.4 percent) and at Goodwin (50.6). The poorly defined middle belt runs from the De Soto Mine about $11 \mathrm{~km}(7 \mathrm{mi})$ west of Cordes to a point $3 \mathrm{~km}(2 \mathrm{mi})$ south of Crown King. No analyses are available for sites in the middle belt. The east belt begins outside of the PNF almost due east of Humbolt in private or BLM land. It extends south through MayerSoddard, Blue Bell Siding, intersecting in the Bradshaw RD before or at the Blue Bell mine, south to Townsend Butte where it becomes two parallel belts extending south to a point about $6 \mathrm{~km}(4 \mathrm{mi})$ northwest of Rock Spring. The highest $\mathrm{SiO}_{2}$ content reported from samples in the east belt were from the Blue Bell mine (52.4 percent). It is notable that $\mathrm{SiO}_{2}$ contents seems to be identical for taconites and jaspilites. Materials from these belts were not available from the one mineral vendor checked in Tucson; however hematite in jasper is available from other areas. 


\section{Other lapidary materials}

Blair (1992) identifies two notable locations for jasper and agate in the PNF. One location for jasper is at Rodeo Flats about 9 miles southeast of Camp Verde (as the crow flies) and just to the east of Cedar Bench Wilderness. The jasper is found in the area in and adjacent to sections 10,11, 14, and 15, T12N R5E. The material is described as red and yellow jasper with some blue banding. The second location is an agate field 6.3 miles south of Perkinsville. The material is multicolored. Some is pastel pink (Blair, 1992).

\section{Where are possible sources of mineral specimens?}

Collectors pay the most for gold-bearing specimens. Most of these are found in alluvial gold placers in watersheds with bed rock hosting gold and other types of mineralization. A number of placer areas have been recognized in the PNF areas (see gold in Table 5); these are the same areas most likely to have additional gold grains and nuggets of interest to collectors. Gold specimens are likely to be found after major flooding has occurred in the watershed.

Beryl and tourmaline minerals seem to demand higher prices than other mineral specimens; garnets fetch a somewhat lesser price (fig. 17). Pegmatites have been the primary source of beryl and tourmaline in the PNF area (Table 5). Spessartine, a member of the garnet group, is found in nearly all the pegmatites of the White Picacho District, southwest of the PNF. Pegmatites within the PNF may also be a source of specimens of these three minerals.

Specimens of lead minerals tend to be more valuable than other metallic minerals (fig. 17). Cerussite, galena, and wulfenite are the minerals involved. Cerussite is commonly noted with the widespread sulfide mineralization in the PNF; galena is an important ore mineral at some mines. Wulfenite, a secondary mineral, is uncommon in Arizona and is noted at just one mine in the PNF--the Fat Jack mine, Bradshaw Mountains (Table 5).

Fluorite ranks fifth in price for specimen minerals (fig. 17). It is widespread and common in the PNF. Fluorite is found in veins, as a gangue mineral with sulfides, in carbonate rocks, and in plutonic igneous rocks.

Pyrite ranks sixth in price for specimen minerals (fig. 17). However specimen prices also vary widely. It is the most common mineral of all sulfide minerals in the PNF. One of the largest pyritic orebodies in the world was found in the PNF (Table 5).

Copper minerals included azurite, chalcocite, chalcopyrite, chrysocolla, malachite, and native copper. Copper minerals also have a median price comparable to the gypsum, calcite, and quartz specimen minerals. All theses 
copper minerals can be found in Table 5 and most are not uncommon in the wide spread sulfide mineralization found in the PNF area.

Gypsum and selenite are found in some sulfide mineralization as well as in the lacustrine deposits of the Verde River basin. Other specimen minerals include calcite (discussed above). Quartz minerals and sphalerite are also seen in some of the sulfide mineralization (Table 5). Epidote is found in lenses in schist and with basic igneous rocks at the Iron King mine (Table 5).

Because minerals are recognized in the PNF area does not necessary mean they appear in sufficient quantity or have sufficient quality that they could be mined and marketed either in bulk or as specimens. A number of minerals in the PNF have been identified as rare or very rare (excluding those formed during the United Verde mine fire). They include: adamite, antlerite, beudantite, cobaltite, cornwallite, danalite, delafossite, duftite, fornacite, gerhardtite, hidalgorite, paulkerrite, phoenicochroite, and stolzite. Rare minerals are commonly found as secondary minerals associated with sulfide mineralization.

Table 5. Partial list of minerals found in, or adjacent to, areas of the PNF as identified in the compilation by Anthony and others (1995) unless noted otherwise. Districts within the Bradshaw Mountains tend to be included even if they are not in the PNF. See appendix of Anthony and others (1995) for location of mining districts listed in table. Also see U.S. Forest Service (1993) map of the Prescott National Forest at a scale 1; 126,720. Some, but not all, common minerals may be listed. Unusual forms, and associates are more likely to be included. Note that rare, common, and so on, in the comment field usually refers to the mineral status in general and if in Arizona, so noted. Comments are organized in parallel order to locations. General comments are given first. If given, traditional district names are shown in parenthesis.

[Abbreviations in table: w--with; Mts--Mountains; Dist.--District; qtz--quartz; sml--small; Ck-Creek]

\begin{tabular}{|l|l|l|}
\hline \multicolumn{1}{|c|}{ Mineral } & \multicolumn{1}{|c|}{ Location } & \multicolumn{1}{c|}{ Comment } \\
\hline Acanthite & $\begin{array}{l}\text { Dos Oris mine, Hassayampa } \\
\text { district, Bradshaw Mts; Hillside } \\
\text { mine, Big Bug district; Arizona } \\
\text { National mine, Ticonderoga } \\
\text { district; }\end{array}$ & $\begin{array}{l}\text { Important silver ore mineral; } \mathrm{w} \\
\text { silver \& chlorargyrite; } \mathrm{w} \\
\text { arsenopyrite, chalcopyrite, } \\
\text { galena, sphalerite, pyrite, } \\
\text { tetrahedrite; in galena w } \\
\text { freibergite \& in cavities w wire } \\
\text { silver. }\end{array}$ \\
\hline Adamite & $\begin{array}{l}\text { Mayer area (sec 17, T12N, R2W) } \\
\text { prospect }\end{array}$ & $\begin{array}{l}\text { A rare secondary mineral; pale- } \\
\text { green crystalline crusts in qtz } \\
\text { vein associated w alloclasite. }\end{array}$ \\
\hline Agate & see text & see text \\
\hline Andalusite & Bradshaw Mts & $\begin{array}{l}\text { Scattered lenses and } \\
\text { disseminated in schist }\end{array}$ \\
\hline Anglesite & $\begin{array}{l}\text { Copperopolis mine, Castle Creek } \\
\text { district, Bradshaw Mts.; Iron King } \\
\text { mine, Big Bug district }\end{array}$ & Abundant lead oxide \\
\hline
\end{tabular}




\begin{tabular}{|c|c|c|}
\hline Mineral & Location & Comment \\
\hline $\begin{array}{l}\text { Antlerite } \\
\end{array}$ & $\begin{array}{l}\text { Jerome, 3-mm perfect crystal } w \\
\text { chalcopyrite in chlorite schist } \\
\text { fracture }\end{array}$ & A rare secondary mineral \\
\hline Apatite & Iron King mine, Big Bug district & $\begin{array}{l}\text { disseminated grains, needlelike } \\
\text { crystals }\end{array}$ \\
\hline Aragonite & $\begin{array}{l}\text { 1) United Verde Extension mine; } \\
\text { 2) Camp Verde salt deposits }\end{array}$ & $\begin{array}{l}\text { Metastable calcium carbonate; } 2 \text { ) } \\
\text { ball-like aggregates of } \\
\text { pseudohexagonal crystals \& } \\
\text { pseudomorphs after glauberite. }\end{array}$ \\
\hline Arsenopyrite & $\begin{array}{l}\text { 1) United Verde mine \& Shea } \\
\text { property, Verde district; 2) Boggs } \\
\text { mine \& 3) Iron King Mine, Big } \\
\text { Bug District, Bradshaw Mts.; 4) } \\
\text { Prescott area. }\end{array}$ & $\begin{array}{l}\text { Most common arsenic mineral; } \\
\text { 2) as crystals; } 3 \text { ) abundant as } \\
\text { subhedral crystals up to } 1.5 \mathrm{~mm} \\
\text { (some w diamond-shaped } \\
\text { sections) in en echelon veins; 4) } \\
\text { variety danaite found. }\end{array}$ \\
\hline Arsenolite & $\begin{array}{l}\text { United Verde mine, Verde District, } \\
\text { Black Mountains }\end{array}$ & $\begin{array}{l}\text { octahedral crystal in burned ore } \\
\text { (see text) }\end{array}$ \\
\hline Azurite & $\begin{array}{l}\text { 1) Yeager mine, Black Hills } \\
\text { district; 2) several mineralized } \\
\text { bodies in Copper Basin district; } 3 \text { ) } \\
\text { United Verde Extension mine, } \\
\text { Jerome area; }\end{array}$ & $\begin{array}{l}\text { Widely distributed secondary in } \\
\text { oxidized copper occurrences; } 1 \text { ) } \\
\text { fine-quality specimens located; } \\
\text { 2) some are botryoidal; } 3 \text { ) } \\
\text { crystals lining vugs \& as small } \\
\text { radiating spherical aggregates w } \\
\text { malachite in limonitic clay. }\end{array}$ \\
\hline Barite & Bradshaw Mts & $\begin{array}{l}\text { Widespread, relatively common; } \\
\text { usually a gangue mineral in } \\
\text { metal mineral occurrences }\end{array}$ \\
\hline$\overline{\text { Beryl }}$ & Bradshaw Mts & $\begin{array}{l}\text { typically in pegmatitic veins and } \\
\text { dikes }\end{array}$ \\
\hline$\overline{\text { Beudantite }}$ & $\begin{array}{l}\text { Crown King, Tiger (Pine Grove) } \\
\text { district, Bradshaw Mts. }\end{array}$ & $\begin{array}{l}\text { A rare secondary mineral found } \\
\text { in oxidation zones of metal } \\
\text { occurrences; as a greenish crust } \\
\text { w jarosite \& Fe oxides }\end{array}$ \\
\hline Biotite & No notable sites listed & $\begin{array}{l}\text { Most common of the mica group } \\
\& \text { a rock-forming mineral; } \\
\text { widespread in Ariz. }\end{array}$ \\
\hline Bismite & $\begin{array}{l}\text { Swallow mine, Castle Creek } \\
\text { district, So. Bradshaw Mts. }\end{array}$ & $\begin{array}{l}\text { A secondary oxidation mineral } \\
\text { of bismuth minerals }\end{array}$ \\
\hline Bornite & $\begin{array}{l}\text { Bradshaw Mts.; Yeager mine, } \\
\text { Black Hills }\end{array}$ & $\begin{array}{l}\text { Common in copper-bearing } \\
\text { veins }\end{array}$ \\
\hline Bournonite & $\begin{array}{l}\text { Boggs mine, Big Bug District, } \\
\text { Bradshaw Mts. }\end{array}$ & $\begin{array}{l}\text { Common sulfosalts; masses in } \\
\text { qtz \& crystals w pyrite, } \\
\text { chalcopyrite, siderite \& } \\
\text { Actinolite (likely first US recog. } \\
\text { occurrence described in 1890) }\end{array}$ \\
\hline Brochantite & $\begin{array}{l}\text { United Verde Mine, Black Hills, } \\
\text { base of oxidized zone }\end{array}$ & $\begin{array}{l}\text { Fairly common secondary } \\
\text { mineral in oxidized Cu } \\
\text { occurrences; in chlorite schist w } \\
\text { chalcopyrite, antilerite \& } \\
\text { cyanotichite }\end{array}$ \\
\hline
\end{tabular}




\begin{tabular}{|c|c|c|}
\hline Mineral & $\begin{array}{l}\text { Location } \\
\end{array}$ & Comment \\
\hline$\overline{\text { Butlerite }}$ & United Verde mine, Black Hills & $\begin{array}{l}\text { type location, thin crystalline } \\
\text { crust (see text) }\end{array}$ \\
\hline Calciovolborthite & $\begin{array}{l}\text { NW } 1 / 4 \text { section } 18, T 8 N, \text { R1W, } \\
\text { Big Bug District }\end{array}$ & $\begin{array}{l}\text { A rare secondary mineral in } \\
\text { oxidized Va occurrences }\end{array}$ \\
\hline Calcite & (see text) & (see text) \\
\hline Cerussite & $\begin{array}{l}\text { Silver Belt mine, Bradshaw Mts; } \\
\text { also at Iron King mine, Big Bug } \\
\text { district \& Copper Chief Mine } \\
\text { Verde district, Black Hills }\end{array}$ & $\begin{array}{l}\text { Common secondary mineral in } \\
\text { lead occurrences widespread in } \\
\text { Ariz.; w chlorargyrite in } \\
\text { probably ancient workings. }\end{array}$ \\
\hline Chalcanthite & $\begin{array}{l}\text { United Verde Mine, Black Hills; } \\
\text { Springfield mine, Tiger (Crown } \\
\text { King) district; DeSoto mine, } \\
\text { Mayer district }\end{array}$ & $\begin{array}{l}\text { Water-soluble secondary copper } \\
\text { mineral found in crusts; as } \\
\text { stalactites some up to } 0.6 \mathrm{~m} \text { ( } 2 \\
\mathrm{ft} \text { long; fine crystal in dump } \\
\text { timbers; microcrystals. }\end{array}$ \\
\hline Chalcocite & $\begin{array}{l}\text { United Verde mine, Black Hills } \\
\text { and United Verde Extension; } \\
\text { Copper Basin district }\end{array}$ & $\begin{array}{l}\text { Important secondary mineral in } \\
\text { commercial properties of } \\
\text { Arizona; at Ext. large, pure, } \\
\text { massive body; breccia pipes }\end{array}$ \\
\hline Chalcopyrite & $\begin{array}{l}\text { United Verde mine, Black Hills; } \\
\text { Bradshaw Mts, Big Bug district, } \\
\text { Iron King Mine. }\end{array}$ & $\begin{array}{l}\text { Principle mineral in pyritic ore } \\
\text { zone; abundant }\end{array}$ \\
\hline Chlorargyrite & $\begin{array}{l}\text { Dos Oris mine, Hassayampa } \\
\text { district, Bradshaw Mts; } \\
\text { Tuscumbria mine, Bradshaw } \\
\text { district; Tip Top mine, Tip Top } \\
\text { district; Silver Belt mine, Big Bug } \\
\text { district; Swastika mine, Peck } \\
\text { district }\end{array}$ & $\begin{array}{l}\text { (AKA cerargyrite) found in } \\
\text { oxidized silver deposits; } w \\
\text { acanthite \& silver; w stephanite; } \\
\text { w ruby silver; stone hammers } \\
\text { and other tools suggests site was } \\
\text { mined in ancient times; fine } \\
\text { crystals reported. }\end{array}$ \\
\hline Chrysocolla & $\begin{array}{l}\text { Arizona-Dundee, Black Hills; } \\
\text { Whipsaw \& Copperopolis } \\
\text { properties, Castle Creek District, } \\
\text { Bradshaw Mts. }\end{array}$ & $\begin{array}{l}\text { Widespread, and nearly always } \\
\text { present in oxidized copper } \\
\text { deposits; bright-blue material }\end{array}$ \\
\hline Cinnabar & $\begin{array}{l}\text { Copper Basin district, Mercury, } \\
\text { Cinnabar, Queen, Zero Hour, \& } \\
\text { Shylock properties }\end{array}$ & $\begin{array}{l}\text { Found in hot springs and recent } \\
\text { volcanics }\end{array}$ \\
\hline Clinozoisite & Iron King mine, Big Bug district. & $\begin{array}{l}\text { Epidote group, often miss } \\
\text { identified as zoisite; NW contact } \\
\text { diorite w breccia facies occurring } \\
\text { w epidote, chlorite, hornblende }\end{array}$ \\
\hline Cobaltite & $\begin{array}{l}\text { Contact between Bradshaw } \\
\text { Granite and Yavapai schist }\end{array}$ & $\begin{array}{l}\text { Rare mineral in contact } \\
\text { metamorphic rocks and in high- } \\
\text { temperature veins }\end{array}$ \\
\hline $\begin{array}{l}\text { Columbite- } \\
\text { Tantalite }\end{array}$ & $\begin{array}{l}\text { Crown King mine, Tiger Dist., } \\
\text { Bradshaw Mts. }\end{array}$ & $\begin{array}{l}\text { Typically found in lithium- } \\
\text { bearing pegmatites; } 3 \text {-in. } \\
\text { twinned crystal in pegmatite }\end{array}$ \\
\hline Copiapite & $\begin{array}{l}\text { Unite Verde Mine, Jerome, Black } \\
\text { Hills }\end{array}$ & $\begin{array}{l}\text { Fairly common secondary } \\
\text { mineral; } 1 \mathrm{~cm} \text { thick crystalline } \\
\text { formed during burning of pyritic } \\
\text { ore }\end{array}$ \\
\hline Copper & $\begin{array}{l}\text { Unite Verde Mine, Jerome, Black } \\
\text { Hills; also in the Copper Basin }\end{array}$ & $\begin{array}{l}\text { Secondary and develops in } \\
\text { oxidized zone; occasionally }\end{array}$ \\
\hline
\end{tabular}




\begin{tabular}{|c|c|c|}
\hline Mineral & Location & Comment \\
\hline & district. & abundant $w$ cuprite \\
\hline Coquimbite & $\begin{array}{l}\text { Unite Verde Mine, Jerome, Black } \\
\text { Hills }\end{array}$ & $\begin{array}{l}\text { Common mineral in oxides base- } \\
\text { metal deposits; formed during } \\
\text { burning of pyritic ore, an } \\
\text { aluminous variety of mineral }\end{array}$ \\
\hline Cornwallite & $\begin{array}{l}\text { Old Roberston claim } 6.4 \mathrm{~km} \mathrm{(4} \\
\mathrm{mi}) \mathrm{E}, \mathrm{NE} \text { of Mayer }\end{array}$ & $\begin{array}{l}\text { A rare secondary mineral } \\
\text { associated with other copper } \\
\text { arsenates; as films \& coatings }\end{array}$ \\
\hline Covellite & United Verde Ext. mine & fine specimens \\
\hline Cryptomelane & $\begin{array}{l}\text { Burmeister mine, near Mayer, sec } \\
17, \text { T11N R3W }\end{array}$ & $\begin{array}{l}\text { W other manganese oxides } \\
\text { interbedded with volcanic ash, } \\
\text { sediments, and basalt; also w } \\
\text { opalized dolomite spring } \\
\text { deposits }\end{array}$ \\
\hline Cuprite & $\begin{array}{l}\text { United Verde Ext. mine, Verde } \\
\text { Dist.; Copper Basin }\end{array}$ & $\begin{array}{l}\text { Beautiful druses of crystallized } \\
\text { material w copper; massive and } \\
\text { crystalline }\end{array}$ \\
\hline Cyanotrichite & Jerome area & $\begin{array}{l}\text { Oxidized zone within chlorite } \\
\text { schist w chalcopyrite, antlerite, } \\
\text { and brochantite }\end{array}$ \\
\hline Danalite & south of Jerome in the Black Hills & $\begin{array}{l}\text { A rare accessory mineral of } \\
\text { granites and greasiness }\end{array}$ \\
\hline Delafossite & $\begin{array}{l}\text { United Verde mine, Verde District, } \\
\text { Black Mountains }\end{array}$ & $\begin{array}{l}\text { A rare secondary mineral; } \\
\text { occurred as crust of black tabular } \\
\text { crystals up to } 8 \mathrm{~mm} \text { on an edge } \\
\text { on milky qtz. }\end{array}$ \\
\hline Digenite & $\begin{array}{l}\text { United Verde mine, Verde District, } \\
\text { Black Mountains }\end{array}$ & In fire zone, see text \\
\hline Diopside & $\begin{array}{l}\text { Henrietta mine, Big Bug district, } \\
\text { Bradshaw Mts }\end{array}$ & W magnetite \\
\hline Dolomite & Burneister mine near Mayer & $\begin{array}{l}\text { Spring deposit partly replaced } \\
\text { with opal and chalcedony }\end{array}$ \\
\hline Duftite & $\begin{array}{l}\text { unspecified location in the Jerome } \\
\text { area }\end{array}$ & $\begin{array}{l}\text { Rare primary mineral associated } \\
\text { with nickeline. }\end{array}$ \\
\hline Epidote & $\begin{array}{l}\text { Bradshaw Mts.; Iron King mine, } \\
\text { Big Bug district }\end{array}$ & $\begin{array}{l}\text { Lenses in schist; at Iron King, w } \\
\text { clinzoisite in gabbro and diorite }\end{array}$ \\
\hline Erythrite & $\begin{array}{l}\text { Old Prudential Copper Co., Black } \\
\text { Hills, }\end{array}$ & $\begin{array}{l}\text { Powdery incrustations on } \\
\text { cobaltite }\end{array}$ \\
\hline Fluorite & $\begin{array}{l}\text { Bradshaw Mts, (Tiger) Pine } \\
\text { Grove District, Springfield Group; } \\
\text { Castle Creek District, Swallow } \\
\text { Mine }\end{array}$ & $\begin{array}{l}\text { Widespread and common } \\
\text { mineral in veins, gangue mineral } \\
\text { w sulfides, carbonate rocks, and } \\
\text { plutonic igneous rocks. }\end{array}$ \\
\hline Fornacite & $\begin{array}{l}\text { Contellation mine, location in } \\
\text { Yavapai Co. not determined }\end{array}$ & Very rare secondary mineral \\
\hline Garnet group & & See Spessartine \\
\hline Galena & $\begin{array}{l}\text { Bradshaw Mts properties; Black } \\
\text { Hills }\end{array}$ & $\begin{array}{l}\text { At some locations is the most } \\
\text { abundant ore mineral }\end{array}$ \\
\hline Gerhardtite & United Verde Mine & Rare secondary mineral \\
\hline Glauberite & $\begin{array}{l}3.2 \mathrm{~km}(2 \mathrm{mi}) \mathrm{S} \text { of Camp Verde in } \\
\text { Copper and Lucky Canyons }\end{array}$ & $\begin{array}{l}\text { Found in sedimentary salt } \\
\text { deposits and } \mathrm{w} \text { fumaroles }\end{array}$ \\
\hline Goethite & No notable site given & Second most common iron \\
\hline
\end{tabular}




\begin{tabular}{|c|c|c|}
\hline Mineral & Location & Comment \\
\hline & & $\begin{array}{l}\text { oxide; essentially ubiquitous in } \\
\text { nearly all mineralized area in } \\
\text { Ariz. }\end{array}$ \\
\hline Gold & $\begin{array}{l}\text { Verde district, Black Hills; Big } \\
\text { Bug, Peck, Walker and Tiger } \\
\text { districts, Bradshaw Mts; Pine } \\
\text { Grove district; Copper Basin area. }\end{array}$ & $\begin{array}{l}\text { Prognosis of finding specimen } \\
\text { gold in accessible locations are } \\
\text { quit low under usual conditions. }\end{array}$ \\
\hline $\begin{array}{l}\text { Gold, in placer } \\
\text { deposits }\end{array}$ & $\begin{array}{l}\text { Copper Basin, Lynx Creek, Big } \\
\text { Bug, also Hum Bug, Castle Rock } \\
\text { Creek, Silver Mountain, Granite } \\
\text { Creek, Black Rock, Tip Top, } \\
\text { Walnut Grove }\end{array}$ & $\begin{array}{l}\text { Most important localities of } \\
\text { historical production listed first } \\
\text { (Moore, 1969); gold nugget } \\
\text { specimens are more likely to be } \\
\text { found after seasonal flooding but } \\
\text { more likely after major flood } \\
\text { events. }\end{array}$ \\
\hline Guildite & United Verde Mine & See text. \\
\hline Gypsum & Salt deposits, Verde basin & $\begin{array}{l}\text { Widespread common mineral } \\
\text { particularly in lacustrine } \\
\text { deposits \& in some sulfide ores; } \\
\text { pseudomorphs after glauberite. }\end{array}$ \\
\hline Halite & Verde Basin & $\begin{array}{l}\text { Some samples deep purple; } \\
\text { associated w glauberite, } \\
\text { gypsum, mirabilite and } \\
\text { thenardite }\end{array}$ \\
\hline Hectorite & $\begin{array}{l}\text { Lyles Hectorite Deposit near } \\
\text { Hillside }\end{array}$ & A swelling clay \\
\hline Hematite & Verde Dist. & $\begin{array}{l}\text { Specular variety in late-stage } \\
\text { veinlets cutting massive sulfides }\end{array}$ \\
\hline Hessite & Verde Dist. & $\begin{array}{l}\text { Small blebs } \mathrm{w} \text { zincian tennantite } \\
\text { in chlorite matrix }\end{array}$ \\
\hline Hidalgorite & $\begin{array}{l}\text { Silver Crown Mine, Tip Top } \\
\text { District (?) }\end{array}$ & $\begin{array}{l}\text { Rare mineral formed during } \\
\text { contact metamorphism of } \\
\text { limestone }\end{array}$ \\
\hline Hurelaulite & White Picacho Dist. & $\begin{array}{l}\text { Amber- to flesh-colored coating } \\
\& \text { crystalline aggregates on } \\
\text { sicklerite }\end{array}$ \\
\hline Jamesonite & Bradshaw Mts. & $\begin{array}{l}\text { Associated w some ores, } \\
\text { particularly those w free gold }\end{array}$ \\
\hline Jeromite & Verde Dist. & See text \\
\hline Jasper & see text & See text \\
\hline Lausenite & Verde Dist. & See text \\
\hline Lithiophilite & $\begin{array}{l}\text { White Picacho district, Midnight } \\
\text { Owl pegmatite }\end{array}$ & Found $\mathrm{w}$ triphylite \\
\hline Magnetite & Bradshaw Mts., Big Bug Creek & $\begin{array}{l}\text { Common as large }(18 \text { in }) \\
\text { boulders in streams }\end{array}$ \\
\hline Malachite & $\begin{array}{l}\text { Yeager Mine, Black Hills; } \\
\text { Piedmont Mine, Bradshaw Mts. }\end{array}$ & $\begin{array}{l}\text { Fine specimen } \mathrm{w} \text { crystallized } \\
\text { azurite; common in oxidized } \\
\text { zones of base-metal deposits in } \\
\text { the area; Fine malachite } \\
\text { pseudomorph after azurite, } \\
\text { coated w white qtz }\end{array}$ \\
\hline Marcasite & Big Bug Dist., Bradshaw Mts & Sml colloform masses in \\
\hline
\end{tabular}




\begin{tabular}{|c|c|c|}
\hline Mineral & Location & Comment \\
\hline & & oxidized ore \\
\hline Microcline & pegmatities & $\begin{array}{l}\text { Rock-forming potassium } \\
\text { feldspar mineral }\end{array}$ \\
\hline Mimetite & Bradshaw Mts.; Slate Ck property & $\begin{array}{l}\text { Botryoidal crusts } \mathrm{w} \\
\text { pyromorphite \& mottramite }\end{array}$ \\
\hline Mottramite & Bradshaw Mts.; Slate Ck property & $\begin{array}{l}\text { An uncommon secondary } \\
\text { mineral; found w pyromorphite } \\
\& \text { mimetite at location }\end{array}$ \\
\hline Olivine & Iron King mine, Big Bug Dist. & $\begin{array}{l}\text { Phenocrysts } w \text { augite in } \\
\text { porphyritic basalt flow w } \\
\text { mineralized volcanic breccias }\end{array}$ \\
\hline Orthoclase & $\begin{array}{l}\text { Near Middletown site on Crown } \\
\text { King road, Bradshaw Mts. }\end{array}$ & $\begin{array}{l}\text { Rock-forming alkali feldspar } \\
\text { mineral; relatively pure material } \\
\text { is noted. }\end{array}$ \\
\hline Osarizawaite & Fat Jack Mine (?) & $\begin{array}{l}\text { W stolzite, cerussite, } \\
\text { pyromorphite, and motramite }\end{array}$ \\
\hline Paragonite & Governors Peak quadrangle & In schist \\
\hline Paulkerrite & $\begin{array}{l}7 \text { 7U ranch near Hillside (location } \\
\text { highly uncertain) }\end{array}$ & $\begin{array}{l}\text { Rare mineral; type and only } \\
\text { location; found as a small minute } \\
\text { vitreous crystals associated } \mathrm{w} \\
\text { secondary phosphate minerals }\end{array}$ \\
\hline Phillipsite & Cottonwood Basin; Verde Valley & Zeolite in altered tuff \\
\hline Phoenicochroite & $\begin{array}{l}\text { Junction of Hassayampa River and } \\
\text { Amazon Wash }\end{array}$ & $\begin{array}{l}\text { Rare secondary mineral in } \\
\text { oxidized galena-bearing veins; } \\
\text { found at location w mimetite, } \\
\text { hemihedrite, and descloiszite }\end{array}$ \\
\hline Piemontite & $\begin{array}{l}\text { NW of Prescott in Government } \\
\text { Canyon }\end{array}$ & $\begin{array}{l}\text { Small veinlets and disseminated } \\
\text { grains in the Prescott } \\
\text { granodorities }\end{array}$ \\
\hline Plagioclase & $\begin{array}{l}\text { no notable sites noted in Yavapai } \\
\text { Co. }\end{array}$ & $\begin{array}{l}\text { Most abundant mineral in the } \\
\text { upper crust; }\end{array}$ \\
\hline$\overline{\text { Polybasite }}$ & $\begin{array}{l}\text { Davis Mine, Hassayama Dist., } \\
\text { Bradshaw Mts.; Tip Top Mine, } \\
\text { Tip Top dist. }\end{array}$ & $\begin{array}{l}\text { W prousitite; w pyrargyrite and } \\
\text { tetrahedrite in qtz veins. }\end{array}$ \\
\hline Proustite & $\begin{array}{l}\text { Davis \& Catoctin mines, } \\
\text { Hassayampa dist.; Turkey Ck } \\
\text { dist;:; Tip Top Mine, Tip Top dist } \\
\text { all in Bradshaw Mts. }\end{array}$ & $\begin{array}{l}\text { W polybasite; w silver \& } \\
\text { chlorargyrite; w silver and } \\
\text { chlorargyrite }\end{array}$ \\
\hline Pyrite & $\begin{array}{l}\text { 1) United Verde mine, Verde } \\
\text { district, 2) numerous occurrences } \\
\text { in the Jerome \& Bradshaw Mts. }\end{array}$ & $\begin{array}{l}\text { Most common of all sulfide } \\
\text { minerals; 1) ore body was } \\
\text { among largest pyritic orebody in } \\
\text { the world. }\end{array}$ \\
\hline Pyromorphite & $\begin{array}{l}\text { 1) Slate Ck prop., \& 2) Fat Jack } \\
\text { Mine (?), Bradshaw Mts }\end{array}$ & $\begin{array}{l}\text { Uncommon mineral in oxidized } \\
\text { lead deposits; 1) tiny trans. light } \\
\text { green barrel -shaped tiny crystals } \\
\text { w mottramite \& botryoidal crusts } \\
\text { 2) green crust }\end{array}$ \\
\hline Quartz crystals & $\begin{array}{l}\text { 1) Cash mine, Hassayampa dist. } \\
\text { 2) Yankee Boy mine dump ( } 9.6 \mathrm{~km} \\
\text { (6 mi) E Mayer) 3) Fat Jack Mine } \\
\text { near Crown King Mine }\end{array}$ & $\begin{array}{l}\text { Open veins lined w clear qtz } \\
\text { crystals w adularia, calcite, } \\
\text { sulfides; 2) } 5 \mathrm{~mm} \text { double } \\
\text { terminated crystal, also smaller }\end{array}$ \\
\hline
\end{tabular}




\begin{tabular}{|c|c|c|}
\hline Mineral & Location & Comment \\
\hline & & $\begin{array}{l}\text { simper twins; } 3 \text { ) smoky crystals } \\
\text { w many specters, amethysts, } \\
\text { phantoms, etc. }\end{array}$ \\
\hline Ransomite & Verde Dist. & See text \\
\hline Realgar & $\begin{array}{l}\text { Castle Hot Springs, Bradshaw } \\
\text { Mts. }\end{array}$ & $\begin{array}{l}\text { Commonly found } \mathrm{w} \text { orpiment, } \\
\text { its alteration product }\end{array}$ \\
\hline Robertsite & White Picacho Dist. & Pegmatites \\
\hline$\overline{\text { Römerite }}$ & United Verde Dist. & $\begin{array}{l}\text { Thin crusts on pyrite formed } \\
\text { under fumerolic conditions as } \\
\text { result of burning pyritic ores. }\end{array}$ \\
\hline$\overline{\text { Rutile }}$ & $\begin{array}{l}\text { 1) Black Canyon district, } \\
\text { Bradshaw Mts. 2)United Verde } \\
\text { mine, Black Hills }\end{array}$ & $\begin{array}{l}\text { 1) tourmaline w gangue 2) well- } \\
\text { developed crystals }\end{array}$ \\
\hline Scapolite Group & $\begin{array}{l}9.6 \mathrm{~km}(6 \mathrm{mi}) . \text { S Cleator, Black } \\
\text { Canyon Dist., Bradshaw Mts. }\end{array}$ & Hosted by Yavapai Schist \\
\hline Scheelite & $\begin{array}{l}\text { 1) Tip Top Dist., Hassayampa } \\
\text { Dist. \& White Picacho Dist. } \\
\text { Bradshaw Mts }\end{array}$ & $\begin{array}{l}\text { Widely distributed in small } \\
\text { amounts in Arizona }\end{array}$ \\
\hline Sicklerite & White Picacho Dist. & $\begin{array}{l}\text { Thin discontinuous rims on } \\
\text { lithiophilite and triphylite }\end{array}$ \\
\hline Siderite & $\begin{array}{l}\text { 1) Lynx Creek, Bradshaw Mts.; 2) } \\
\text { Peck \& Swasline mines, Peck } \\
\text { district; 3) Stonewall Jackson mine } \\
\text { near Prescott; 4) Shea, Brindle } \\
\text { Pup, \& Mingus Mt. mines, Black } \\
\text { Hills. }\end{array}$ & $\begin{array}{l}\text { 1) Veins w chlorite \& } \\
\text { tourmaline; 2) w silver \& } \\
\text { bromargyrite; 3) as gangue w } \\
\text { silver, chlorargyrite, and } \\
\text { chalcanthite; 4) in qtz veins w } \\
\text { sulfides. }\end{array}$ \\
\hline Silver & $\begin{array}{l}\text { 1) United Verde mine, Verde } \\
\text { district; Several occurrences in } \\
\text { Bradshaw Mts., 2) Dos Oris mine, } \\
\text { Hassayampa district, Bradshaw } \\
\text { Mts; 3) Arizona-National mine, } \\
\text { Big Bug District; 4) Tip Top } \\
\text { mine, Tip Top district }\end{array}$ & $\begin{array}{l}\text { 1) Common in upper part of } \\
\text { silver-bearing deposits } \\
\text { particularly as a thin, high } \\
\text { grade gossan above sulfide ore; } \\
\text { 2) w acanthite and chlorargyite; } \\
\text { 3) wire silver in cavities w } \\
\text { acanthite; 4) w ruby silver and } \\
\text { chlorargyrite }\end{array}$ \\
\hline Spessartine & White Picacho Dist. & $\begin{array}{l}\text { Found in nearly all pegmatites, } \\
\text { up to } 0.5 \text { in in diameter }\end{array}$ \\
\hline Sphalerite & $\begin{array}{l}\text { Many districts of the Bradshaw } \\
\text { Mts }\end{array}$ & $\begin{array}{l}\text { An abundant and wide spread } \\
\text { mineral }\end{array}$ \\
\hline$\overline{\text { Staurolite }}$ & Bradshaw Mts & $\begin{array}{l}\text { Near contacts of granitic } \\
\text { intrusives in schist. }\end{array}$ \\
\hline Stibnite & $\begin{array}{l}\text { Tip Top Dist., Bradshaw Dist; } \\
\text { Malley Hill Mine, Lynx Ck. }\end{array}$ & $\begin{array}{l}\text { Found in low-temperature } \\
\text { hydrothermal veins; important } \\
\text { source of antimony }\end{array}$ \\
\hline Stolzite & Fat Jack Mine, Bradshaw Mts. & $\begin{array}{l}\text { Rare secondary mineral of } \\
\text { scheelite group; rough, cubic to } \\
\text { platy cystal up to } 5 \mathrm{~cm} \mathrm{w} \\
\text { pyromorphite, mottramite \& gtz }\end{array}$ \\
\hline$\overline{\text { Sulfur }}$ & United Verde Mine & $\begin{array}{l}\text { Formed from partial burning of } \\
\text { pyritic ore }\end{array}$ \\
\hline Tennantite & $\begin{array}{l}\text { United Verde Mine; Iron King } \\
\text { Mine, Big Bug Dist. }\end{array}$ & $\begin{array}{l}\text { Common, widespread sulfosalt } \\
\text { in hydrothermal vein deposits. }\end{array}$ \\
\hline
\end{tabular}




\begin{tabular}{|l|l|l|}
\hline \multicolumn{1}{|c|}{ Mineral } & \multicolumn{1}{|c|}{ Location } & \multicolumn{1}{c|}{ Comment } \\
\hline Tetradymite & $\begin{array}{l}\text { Montgomery Mine, Bradshaw } \\
\text { Mts.; 2 mile S Bradshaw City }\end{array}$ & $\begin{array}{l}\text { Uncommon; second local found } \\
\text { as bladed crystals in qtz, pyrite }\end{array}$ \\
\hline Torbernite & $\begin{array}{l}\text { in pegmatities, lenses in schist, } \\
\text { Bradshaw Granite, Bradshaw } \\
\text { Mts.; Iron King Mine }\end{array}$ & $\begin{array}{l}\text { Common mineral associated w } \\
\text { contact-metamorphism }\end{array}$ \\
\hline Tourmaline group & $\begin{array}{l}\text { Pegmatites of the Bradshaw } \\
\text { Granite; Iron King mine, Big Bug } \\
\text { district }\end{array}$ & $\begin{array}{l}\text { Most abundant as a black, iron- } \\
\text { bearing schorl; also in lenses in } \\
\text { schist particular along granite } \\
\text { contacts; blue-gray prisms w qtz } \\
\text { \& dolomite. }\end{array}$ \\
\hline Vanadinite & $\begin{array}{l}\text { Adjacent to Silver Belt mine, Big } \\
\text { Bug Dist. }\end{array}$ & $\begin{array}{l}\text { Comparatively rare in oxidized } \\
\text { lead deposits; at site noted as } \\
\text { 0.25-in. yellow-brown crystals. }\end{array}$ \\
\hline Wolframite & $\begin{array}{l}\text { Tip Top mine, Thule Creek, } \\
\text { Bradshaw Mts; Silver Mountain } \\
\text { Dist. }\end{array}$ & $\begin{array}{l}\text { Widespread in Ariz.; most } \\
\text { abundant in qtz veins in granites, } \\
\text { schists assoc. w pegmatities. }\end{array}$ \\
\hline Wulfenite & Fat Jack mine, Bradshaw Mts & $\begin{array}{l}\text { Uncommon, secondary mineral; } \\
\text { at site noted as small crystals w } \\
\text { stolzite }\end{array}$ \\
\hline Zircon & $\begin{array}{l}\text { Bradshaw Granite, Bradshaw Mts; } \\
\text { Kirkland-Copper basin placers }\end{array}$ & $\begin{array}{l}\text { Spare in granite; abundant in } \\
\text { placer black sands. }\end{array}$ \\
\hline Zoisite & Bradshaw Mts & Scattered lenses in schist \\
\hline
\end{tabular}

\section{References Cited}

Anderson, C.A., Scholz, E.A. , and Strobell, J.D., Jr., 1955, Geology and ore deposits of the Bagdad area, Yavapai County, Arizona: U.S. Geological Survey Professional Paper 278, 103 p.

Anthony, J.W., Williams, S.A., Bideaux, R.A., and Grant, R.W., 1995, Mineralogy of Arizona: Tucson, University of Arizona Press, 508 p. Appleyard, F.C., 1983, Gypsum and anhydite, in Lefond, S.J., ed., Industrial minerals and rocks: New York, Society of Mining Engineers, v. 2, p. 775-792.

Arizona Bureau of Mines [Arizona Geological Survey], 1958, Geologic map of Yavapai County, Arizona: Tucson, Arizona Bureau of Mines [Arizona Geological Survey] and University of Arizona, scale 1:375,000.

Arizona Department of Transportation, 1975, A materials inventory of Coconino County: Arizona Department of Transportation, Highway Division' and Federal Highway Administration, 123 p.

Arizona Department of Transportation, 1990, Standard specifications for road and bridge construction: Arizona Department of Transportation, Highway Division, 800 p.

Arizona Highway Department, 1972, A materials inventory of Yavapai County: Arizona Highway Department and Federal Highway Administration, $65 \mathrm{p}$. 
ASTM, 1993, Annual book of ASTM standards: American Society for Testing and Materials (ASTM) , v. 04.02, p. 10-15.

Austin, G.S., and Mojtabai, Cynthia, 1996, Cat litter--a growing market for industrial minerals, in Austin, G.S., Hoffman, G.K., Barker, J.M., Zidek, Jiri, and Gilson, Nancy, eds., Proceedings of the 31st Forum on the geology of industrial minerals--the borderland forum: New Mexico Bureau of Mines and Mineral Resources Bulletin 154, p. 267-273

Baek, Hwanjo, 1997, Effect of the rock fabrics on the physical properites of a granite [abs.]: Geological Society of America Abstracts with Program, v. 29 no. 6, p. A-447.

Billingsley, G.H., Conway, C.M., and Beard, L.S. , 1988, Geological map of the Prescott 30-x 60- minute quadrangle, Arizona: U.S. Geological Survey Open-File Report 88-372, scale 1:100,000.

Blair, Gerry, 1992, Rockhounding Arizona: Helena, Mont., Falcon Press Publishing Co., $165 \mathrm{p}$.

Bliss, J.D., 1993, Mineral resource assesment of undiscovered mineral deposits for selected mineral deposit types in the Kaibab National Forest, Arizona, with a section on Mineral resource assessment of solutioncollapse breccia pipe uranium deposits by J.D. Bliss and Charles T. Pierson: U.S. Geological Survey Open-File Report 93-329, 67 p.

Bliss, J.D., 1997, Mineral resource assessment of selected nonmetallic and metallic resources of the Coconino National Forest, Arizona: U.S. Geological Survey Open-File Report 97-486, $262 \mathrm{p}$

Brattli, Bjørge, 1992, The influence of geological factors on the mechanical properties of basic igneous rocks used as road surface aggregates: Engineering Geology, v. 33, no. 1, p. 31-44.

Bryant, B.H., Conway, C.M., Spencer, J.E., Reynolds, S.J., Otton, J.E., and Blacet, P.M., 1992, Geological map and cross section across the boundary between the Colorado Plateau and the Basin and Range southwest of Bagdad, Arizona: U.S. Geological Survey Open-File Report 92-428, scale 1:100,000.

Bryant, Bruce, 1995, Geological map, cross sections, isotopic dates, and mineral deposits of the Alamo Lake 30' X 60' quadrangle, west-central Arizona: U.S. Geological Survey Miscellaneous Investigations Series Map I-2489, scale $1: 100,000$.

Clarke, G., 1985, Special clays: Industrial Minerals, no. 216, p. 25-48.

Conway, C.M., and Gonzales, D.M., 1995, Greenvillian tectonic setting of the 1.1-Ga diabase province in the southwestern United States: Leon $\mathrm{T}$. Silver 70th birthday symposium, Pasadena, California Institute of Technology, p. 185-190.

Cox, L.J., 1995, An evaluation of sand and gravel resources in and near the Verde Valley of the Coconino National Forest, Arizona: U.S. Geological Survey Open-File Report 95-31, 1 sheet, scale 1:126,720, 20 p. 
Cox, L.J., 1999, An evaluation of sand and gravel resources in and near the Prescott National Forest in the Verde Valley, Arizona, with a section on Evaluation of sand and gravel resources using selected engineering variables by J. D. Bliss and Robert J. Miller: U.S. Geological Survey Open-File Report 99-127, 38 p.

DeWitt, Ed, 1979, New data concerning Proterozoic volcanic stratigraphy and structure in central Arizona and its importance in massive sulfide exploration: Economic Geology, v. 74, p. 1371-1382.

DeWitt, Ed, 1987, Proterozoic ore deposits of the southwestern United States: Society of Economic Geologists, Guidebook Series Volume 1, 189 p.

Drake, Bob, 1995, Comment--finding answers to the fines problem: Rock Products, v. 98, no. 9, p. 25.

Funnell, J.E., and Wolfe, E.J., 1964, Compendium on nonmetallic minerals of Arizona: San Antonio, Texas, Southwest Research Institute Report, 335 p. [prepared for the Arizona Public Service Company, Phoenix, Arizona]

Goldman, H.B., 1994, Sand and Gravel, in Carr, D.D., ed., Industrial minerals and rocks (6th ed.): Littleton, Colo., Society for Mining, Metallurgy, and Exploration, Inc., p. 869-877.

Hammond, J.G., 1990, Middle Proterozoic diabase intrusions in the southwestern U.S. A. as indicators of limited extensional tectonics, in Gower, C.F., Rivers, T., and Ryan, B., eds., Mid-Proterozoic LaurentiaBaltica: Geological Association of Canada Special Paper 38, p. 517-531.

Harben, P.W., 1995, The industial minerals HandyBook: London, Metal Bulletin PLC, $253 \mathrm{p}$.

Harben, P.W., and Bates, R.L., 1984, Geology of the nonmetallics: New York, Metal Bulletin Inc., $392 \mathrm{p}$.

Harben, P.W., and Bates, R.L., 1990, Industrial minerals geology and world deposits: New York, Metal Bulletin Inc., 312 p.

Harben, P.W., and Milos, Kuzvart., 1996, Industrial minerals--a global geology: London, Metal Bulletin Inc., $462 \mathrm{p}$.

Harrer, C.M., 1964, Reconnaissance of iron resources in Arizona: U.S. Bureau of Mines Information Circular 8236, $204 \mathrm{p}$.

Hay, R.L, 1978, Geologic occurrence of zeolites, in Sand, L.B. and Mumpton, F.A., eds., National zeolites--occurrences, properties, use: New York, Pergamon Press, p. 135-143.

Hay, R.L, 1978, Geology of zeolites in sedimentary rocks, in Mumpton, F.A., ed., Geology of national zeolites: Review in Mineralogy, v. 4, p. 1651754.

Heaman, L.M., and Grotzinger, J.P., 1992, 1.08 Ga diabase sills in the Pahrump Group, California; implications for development of the Cordilleran miogeocline: Geology, v. 21, p. 637-640

Hopkins, R.L., 1990, Kaibab Formation, in Beus, S.S., and Morales, Michael, eds., Grand Canyon geology: New York, Oxford University Press, p. 225-245. 
House, P.K, 1994, Surficial geology of the southern Verde Valley, Yavapai County, Arizona: Arizona Geological Survey Open-File Report 94-23, 20 p., 3 map sheets, scale 1: 24,000.

House, P.K, and Pearthree, P.A., 1993, Surficial geology of the northern Verde Valley, Yavapai County, Arizona: Arizona Geological Survey OpenFile Report 93-16, 19 p., 4 map sheets, scale 1: 24,000.

Houser, B.B., 1992, Map of industrial mineral occurrences in the National Forests of Arizona: U.S. Geological Survey Open-File Report 92-687, scale $1: 500,000,1$ sheet, $30 \mathrm{p}$.

Howard, K.A., 1991, Intrusion of horizontal dikes; tectonic significance of Middle Proterozoic diabase sheets widespread in the upper crust of the southwestern United States: Journal of Geophysical Research, v. 96, p. $12,461-12,478$.

Huhta, R.S., 1991. Introduction to the aggregate industry, in Barksdale, R.D. ed, The aggregate handbook: Washington, D.C., National Stone Association, p. 1-1 to 1-14.

Keith, S.B., 1969a, Gypsum and anhydrite, in U.S. Geological Survey, Arizona Bureau of Mines, and U.S. Bureau of Reclamation, Mineral and water resources of Arizona: United States, Senate, 90th Congress, 2d Session, p. 371-382.

Keith, S.B., 1969b, Limestone, dolomite, and marble, in U.S. Geological Survey, Arizona Bureau of Mines, and U.S. Bureau of Reclamation, Mineral and water resources of Arizona: United States, Senate, 90th Congress, 2d Session, p. 385-398.

Kiersch, G.A., 1955, Construction materials: Tucson, University of Arizona Press, v. III, 81 p.

Klemic, Harry, 1969, Iron, in U.S. Geological Survey, Arizona Bureau of Mines, and U.S. Bureau of Reclamation, Mineral and water resources of

Arizona: United States, Senate, 90th Congress, 2d Session, p. 168-182.

Krieger, M.H., 1965, Geology of the Prescott and Paulden quadrangles, Arizona: U.S. Geological Survey Professional Paper 467, 127 p.

Lane, M.E., 1992, Mineral appraisal of the Coconino National Forest, Arizona: U.S. Bureau of Mines Mineral Land Assessment Open-File Report MLA 11-92, 93 p., 3 sheets, scale 1:126,720

Langer, H. W., and Jahn, D.W., 1996, How specifications govern the availablity of natural aggregate, in Jones, R.W., and Harris, R.E., eds., Proceedings of the 32nd Annual Forum on the Geology of Industrial Minerals: Wyoming Geological Survey Public Information Circular No. 38, p. 289-294.

Langer, W.H., 1988, Natural aggregate of the Conterminous United States: U.S. Geological Survey Bulletin 1594, 33 p.

Langland, Leo, 1987, Locating, sampling, and evaluating potential aggregate deposits, in Peirce, H.W., ed., 21st forum on the geology of industrial minerals: Arizona Bureau of Geology and Mineral Technology Special Paper 4, p. 116-119. 
Lefond, S.J., ed., 1983, Industrial minerals and rocks: New York, American Institute of Mining, Metallurgical, and Petroleum Engineers, Inc., v. 1, $722 \mathrm{p}$.

Marek, C.R., 1991, Basic properties of aggregate, in Barksdale, R.D., ed., The aggregate handbook: Washington, D.C., National Stone Association, p. 3-1 to 3-81.

Moore, R.T., Wilson, E.D., and O'Haire, R.T., 1960, Geologic map of Coconino County, Arizona: Tucson, Arizona Bureau of Mines [Arizona Geological Survey] and University of Arizona, 1 sheet, scale 1:375,000.

Nealey, L.D., and Sheridan, M.F., 1989, Post-Laramide volcanic rocks of Arizona and northern Sonora, Mexico, and their inclusions, in Jenney, J.P. and Reynolds, S.J., Geologic evolution of Arizona: Arizona Geological Society Digest 17, p. 609-647.

Newhall, C.G., Ulrich, G.E., and Wolfe, E.W., 1987, Geologic map of the southwest part of the San Francisco volcanic field, north-central Arizona: U.S. Geological Survey Miscellaneous Field Studies Map MF1958 , 58 p., 2 sheets, scale 1:50,000.

O'Driscoll, Mike, 1990, Minerals in the US south-west: Industrial Minerals, no. 272 , p. $52-87$.

O'Driscoll, Mike, 1992, European cat litter; absorption market growth: Industrial Minerals, no. 299, p. 46-65.

Orris, G.J., 1992a, Preliminary constituent models of sodium carbonate (sulfate, chloride) brine, in Orris, G.J., and Bliss, J.D., ed., Industrial mineral deposit models; grade and tonnage models: U.S. Geological Survey Open-File Report 92-437, p. 63-66.

Orris, G.J., 1992b, Preliminary descriptive model of lacustrine borates, in Industrial mineral deposit models--descriptive model for three lacustrine deposit types: U.S. Geological Survey Open-File Report 92593, p. 2-6.

Orris, G.J., 1992c, Preliminary descriptive model of lacustrine gypsum, in Industrial mineral deposit models--descriptive model for three lacustrine deposit types: U.S. Geological Survey Open-File Report 92593, p. 7-10.

Orris, G.J., 1992d, Preliminary descriptive model of lacustrine halite, in Industrial mineral deposit models--descriptive model for three lacustrine deposit types: U.S. Geological Survey Open-File Report 92593, p. 11-13.

Orris, G.J., 1992e, Preliminary grade and tonnage models of marine bedded gypsum, in Orris, G.J., and Bliss, J.D., ed., Industrial mineral deposit models; grade and tonnage models: U.S. Geological Survey Open-File Report 92-437, p. 60-62.

Panczner, Sharon, and Panczner, Bill, 1988, Gems and minerals of Arizona--a guide to native gemstones: Frederick, Colo., Renaissance House, 48 p.

Pearthree, P.A., 1993, Geologic and geomorphic setting of the Verde River from Sullivan Lake to Horseshoe Reservoir: Arizona Geological Survey Open-File Report 93-4, 25 p. 5 map sheets, scale 1: 24,000. 
Phillips, K.A., 1987, Arizona industrial minerals: Phoenix, Arizona, Arizona Department of Mines and Mineral Resources Report 4, 2nd edition, 185 p.

Phillips, K.A., Niemuth, N.J., and Bain, D.R., 1998, Active mines in Arizona 1999: Arizona Department of Mines and Mineral Resources Dirctory $47,28 \mathrm{p}$.

Podolsky, George, and Keller, D.P., 1994. Pigments, iron oxide, in Carr, D.D., and others, eds., Industrial minerals and rocks: Littleton, Colo., Society for Mining Metallurgy, and Exploration, p. 765-781.

Potochnik, A.R., 1989, Depositional style and tectonic implications of the Mogollon Rim Formation (Eocene), east-central Arizona: New Mexico Geological Society Guidebook, 40th Field Conference, Southeastern Colorado Plateau, p. 107-118.

Raup, O.B., 1991, Descriptive model of bedded gypsum; deposit subtype; marine evaporite gypsum (model 35ae), in Orris, G.J., and Bliss, J.D., eds., Industrial mineral deposit models--descriptive deposit models: U.S. Geological Survey Open-File Report 91-11a, p. 34-35.

Santarén, J., and Alvarez, A., 1994, Assessment of the health effects of mineral dusts: Industrial Minerals, no. 319, p. 101-117.

Schrader, F.C., 1909, Mineral deposits of the Cerbat Range, Black Mountains, and Grand Wash Cliffs: U.S. Geological Survey Bulletin 397, 226 p.

Shenk, J.D., 1992, Lacustrine diatomite, in Industrial mineral deposit models-descriptive model for three lacustrine deposit types: U.S. Geological Survey Open-File Report 92-593, p. 23-25.

Silver, L.T. Williams, I.S., and Woodhead, J.A., 1982a, Uranium in granites from the western U.S.; Actinide parent-daughter systems, sites, and moblization: Department of Energy Open-File Report GJBX-45(81), 380 p.

Silver, L.T., Woodhead, J.A., and Williams, I.S., 1982b, Primary mineral distribution and secondary mobilzation of uranium and thorium in radioactive granites, in Proceedings of the symposium on uranium exploration methods, June, 1982: Paris, OECD Nuclear Energy Agency and International Atomic Energy Agency, p. 357-367.

Simmons, A.M., and Ward, A.W., 1992, Preliminary geologic map of the Mohon Mountains volcanic field, Mohave and Yavapai Counties, Arizona: U.S. Geological Survey Open-File Report 92-198, scale 1:50,000.

Smith, M.R., and Collis, L., 1993, eds., Aggregates; sand, gravel, and crushed rock aggregates for construction purposes: Bath, United Kingdom, Geological Society Special Publication 9, 539 p.

Spunt, E.S., and Brace, W.F., 1974, Direct observation of microcavities in crystalline rock [abs.]: International Journal of Rock Mechanics, v. 11, p. 139-150.

Thomson, M.L., and Grattan-Bellew, P.E., 1993, Anatomy of a porphyroblastic schist; alkali-silica reactivity: Engineering Geology, v. 35, no. 1/2, p. 8191. 
Twenter, F.R., and Metzger, D.G., 1963, Geology and ground water in Verde Valley--the Mogollon Rim Region, Arizona: U.S. Geological Survey Bulletin 1177, 129 p.

U.S. Forest Service, 1993, [Map of the] Prescott National Forest: Prescott, Ariz., U.S. Forest Service, 1 sheet, scale 1:126,720.

Ulrich, G.E., Billingsley, G.H., Hereford, Richard, Wolfe, E.W., Nealey, L.D., and Sutton, R.L., 1984, Map showing geology, struture, and uranium deposits of the Flagstaff $1^{\circ}$ by $2^{\circ}$ quadrangle, Arizona: U.S. Geological Survey Miscellaneous Investigations Map I-1446, scale, 2 sheets, 1:250,000.

Weir, G.W., Ulrich, G.E., and Nealey, L.D., 1989, Geologic map of the Sedona $30^{\prime} X$ 60' quadrangle, Yavapai and Coconino Counties, Arizona: U.S. Geological Survey Miscellaneous Investigations Map I-1896, scale $1: 100,000$.

Weisman, W.I., and McIlveen, Sid, Jr., 1983, Sodium sulfate deposits, in , Lefond, S.J., ed., Industrial Minerals and Rocks (Nonmetallics other than Fuels): New York, American Institute of Mining, Metallurgical, and Petroleum Engineers, Inc., v. 2, p. 1207-1223.

Welty, J.W., Reynolds, S.J., and Spencer, J.E., 1989, AZMIN, a digital database compilation for Arizona's metallic mineral districts: Arizona Geological Survey Open-File Report 89-8, pagination varies.

White, T.D., 1991, Aggregate as a component of portland cement and asphalt concrete, in Barksdale, R.D., ed., The aggregate handbook: Washington, D.C., National Stone Association, p. 13-1 to 13-69.

Wrucke, C.T., and Conway, C.M., 1987, Geologic map of the Mazatzal Wilderness and contiguous roadless areas, Gila Maricopa, and Yavapai Counties, Arizona: U.S. Geological Survey Open-File Report 87-664, scale $1: 48,000$.

Zdunczyk, M.J., 1991, Importing construction aggregate to the continental United States, in Drakapoulos, Yolanda, ed., Proceedings of an international symposium, Caribbean industrial minerals; new frontiers for investment: Kingston, Jamaica, Symposium, Nov. 13-17, 1989, Journal of the Geological Society of Jamaica, Special Issue No. 11, p., 99103. 